\author{
UNIVERSIDADE DE SÃO PAULO \\ INSTITUTO DE QUÍMICA DE SÃO CARLOS
}

\title{
DESENVOLVIMENTO DE MATRIZES DE COLÁGENO/NANOHIDROXIAPATITA CONTENDO EXTRATOS VEGETAIS PARA REGENERAÇÃO ÓSSEA
}

Claudio Fernandes Garcia

São Carlos

2020 
Claudio Fernandes Garcia

\section{DESENVOLVIMENTO DE MATRIZES DE COLÁGENO/NANOHIDROXIAPATITA CONTENDO EXTRATOS VEGETAIS PARA REGENERAÇÃO ÓSSEA}

Dissertação apresentada ao Instituto de Química de São Carlos da Universidade de São Paulo como parte dos requisitos para a obtenção do título de mestre em ciências.

Área de concentração: Química Analítica

Orientadora: Profa Dra. Ana Maria de Guzzi Plepis

São Carlos

2020 
Autorizo a reprodução e divulgação total ou parcial deste trabalho, por qualquer meio convencional ou eletrônico para fins de estudo e pesquisa, desde que citada a fonte.

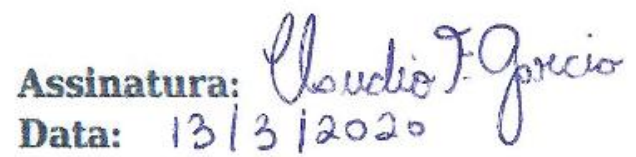

\section{Exemplar revisado}

O exemplar original encontra-se em acervo reservado na Biblioteca do IQSC-USP

Ficha Catalográfica elaborada pela Seção de Referência e Atendimento ao Usuário do SBI/IQSC

Garcia, Claudio Fernandes

Desenvolvimento de matrizes de colágeno/nanohidroxiapatita contendo extratos vegetais para regeneração óssea / Claudio Fernandes Garcia. - São Carlos, 2020.

$110 \mathrm{f}$.

Dissertação (Mestrado em Química Analítica e Inorgânica) - Instituto de Química de São Carlos / Universidade de São Paulo, 2020.

Orientadora: Profa. Dra. Ana Maria de Guzzi Plepis

1. colágeno. 2. nanohidroxiapatita. 3. flavonoide. 4. regeneração óssea. I. Título.

Solange Puccinelli - CRB: $1500 / 8$

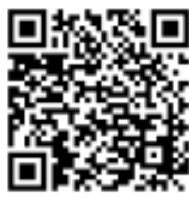




\section{Dedicatória}

Dedico este trabalho à minha mãe e ao meu pai, que me deram apoio e suporte para poder concluir o curso de Química da Universidade de São Paulo e esta dissertação, e a todos os meus amigos que de alguma forma, me ajudaram nessa jornada. 


\section{Agradecimentos}

À Profạ. Dra. Ana Maria de Guzzi Plepis, pela orientação, incentivo, oportunidade e aprendizado durante a realização desta dissertação.

À Dra. Virginia da Conceição Amaro Martins, pelo apoio, incentivo, dedicação e momentos de descontração durante a realização deste trabalho.

Ao Profo Dr. Sérgio Akinobu Yoshioka, pela ajuda e momentos de descontração.

Ao Dr. Marcio de Paula, pelas análises de microscopia eletrônica de varredura e EDX.

À Profa. Dra. Marcia Nitschke, à Me. Marília Cardoso Milanetto e à doutoranda Crisiane Aparecida Marangon, do grupo de Biotecnologia Microbiana, pelos ensaios microbiológicos.

À Profa. Dra. Monica Beatriz Mathor, à pesquisadora Maria Fátima Guarizo Klingbeil e ao Instituto de Pesquisa Energéticas e Nucleares (Ipen), pelo processo de esterilização e ensaios de citotoxicidade.

Ao Laboratório Multiusuário de Cristalografia Estrutural (LAMUCRES) do Grupo de Cristalografia do Instituto de Física de São Carlos (IFSC), em especial ao Sr. José Augusto Lopes da Rocha pelas análises de DRX.

À Central de Análises Químicas do IQSC, em especial ao Sr. Aldimar T. J. Constante pelas análises de FTIR. 
Aos amigos do Grupo de Bioquímica e Biomateriais, pelo aprendizado, apoio, incentivo, amizade e momentos de descontração.

A todos que, de alguma maneira, contribuíram para a elaboração desse trabalho.

Ao Conselho Nacional de Desenvolvimento Científico e Tecnológico (CNPq) pela bolsa concedida (processo 130686/2018-2). 


\section{Resumo}

GARCIA, Claudio Fernandes. Desenvolvimento de matrizes de colágeno/nanohidroxiapatita contendo extratos vegetais para regeneração óssea. 2020. 110 f. Dissertação (Mestrado) - Instituto de Química de São Carlos, Universidade de São Paulo, São Carlos, 2020.

A engenharia de tecido ósseo busca o desenvolvimento de matrizes que tenham composição, nanoestrutura e resposta biológica semelhante ao tecido ósseo natural. Sendo o osso composto por colágeno do tipo I, a proteína fibrosa mais abundante do corpo humano, e hidroxiapatita, uma biocerâmica com propriedades bioativas e osteocondutoras, foram preparadas matrizes utilizando esses biomateriais afim de se obter um material poroso com potencialidade de uso como agente de reconstrução de tecido ósseo. O colágeno aniônico $(\mathrm{C})$ foi obtido a partir da hidrolise alcalina da serosa porcina e a nanohidroxiapatita $(\mathrm{nHA})$ foi sintetizada a partir de brometo de cetrimônio, $\mathrm{K}_{2} \mathrm{HPO}_{4}$ e $\mathrm{CaCl}_{2}$. Extratos de semente de uva $(\mathrm{P})$, casca de romã $(\mathrm{R})$ e casca de jabuticaba $(\mathrm{J})$ foram utilizados como fonte de flavonoides, que apresentam propriedades bactericidas, antioxidantes, anti-inflamatórias e capacidade de ser utilizado como agente reticulante. Assim, foram preparadas oito matrizes denominadas $\mathrm{C}, \mathrm{CP}, \mathrm{CR}, \mathrm{CJ}, \mathrm{CnHA}, \mathrm{CnHAP}, \mathrm{CnHAR}$ e CnHAJ, caracterizadas por DSC (calorimetria exploratória diferencial), para se avaliar a temperatura de desnaturação do colágeno; MEV (microscopia eletrônica de varredura), ensaios de porosidade por imersão em etanol, cinética de absorção de tampão fosfato salino (PBS), degradação via colagenase e ensaios de atividade antimicrobiana e citotoxicidade. O colágeno foi caracterizado por DSC e por espectroscopia na região do infravermelho (FTIR), a nanohidroxiapatita por espectroscopia de energia dispersiva de raios $X(E D X)$ para se avaliar a razão $\mathrm{Ca} / \mathrm{P}$, por $\mathrm{MEV}$, por difração de raios-X (DRX), FTIR e ensaios de citotoxicidade. Os extratos por análises de FTIR e foram caracterizados frente sua citotoxicidade, ação e concentração de flavonoides totais por espectroscopia na região ultravioleta-visível (Uv-vis). A partir disso, observou-se que o extrato de semente de uva apresentou a menor concentração bactericida mínima, sendo de $250 \mathrm{\mu g} \mathrm{mL}^{-1}$ e os três extratos atuaram como agentes reticulantes do biopolímero, aumentando sua resistência enzimática e estabilidade térmica. Foi obtida a hidroxiapatita dentro da escala nanométrica e com razão $\mathrm{Ca} / \mathrm{P}$ igual a 1,60 $\pm 0,03$. Em relação a atividade antimicrobiana apenas a matriz CR apresentou atividade e, dentro da faixa de concentrações testadas, os extratos apresentaram citotoxicidade e a nanohidroxiapatita um aumento na viabilidade celular. As matrizes apresentaram porosidade e tamanho de poros adequados para crescimento ósseo, sendo que em períodos de $24 \mathrm{~h}$ apresentam viabilidade celular superior a $70 \%$ e em períodos de $48 \mathrm{~h}$ as matrizes CR, CnHAP, CnHAR e CnHAJ apresentaram citotoxicidade. Até o momento, conclui-se que apenas as matrizes $\mathrm{C}$, $\mathrm{CP}$, CJ e CnHA poderiam ser utilizadas como biomaterial para regeneração de tecido ósseo, podendo ser utilizadas para a etapa in vivo.

Palavras-chave: colágeno, nanohidroxiapatita, flavonoide, regeneração óssea. 


\begin{abstract}
GARCIA, Claudio Fernandes. Development of collagen/nanohydroxyapatite scaffolds containing plant extract for bone regeneration. 2020. $110 \mathrm{f}$. Dissertação (Mestrado) - Instituto de Química de São Carlos, Universidade de São Paulo, São Carlos, 2020.

Bone tissue engineering aims the development of scaffolds that have composition, nanostructure and biological response similar to natural bone tissue. Once bone is composed of type I collagen, the most abundant fibrous protein in the human body and hydroxyapatite, a bioceramic with bioactive and osteoconductive properties, scaffolds were prepared using these biomaterials in order to obtain a porous material with potential for reconstruction of bone tissue. Anionic collagen $(C)$ was obtained from alkaline hydrolysis of serous porcine and nanohydroxyapatite (nHA) was synthesized from cetrimonium bromide, $\mathrm{K}_{2} \mathrm{HPO}_{4}$ and $\mathrm{CaCl}_{2}$. Grape seed extracts $(\mathrm{P})$, pomegranate peel extract $(R)$ and jabuticaba peel extract $(\mathrm{J})$ were used as a source of flavonoids, which have bactericidal, antioxidant, anti-inflammatory properties and ability to be used as crosslinker. Thus, eight scaffolds named C, CP, CR, CJ, CnHA, CnHAP, CnHAR and CnHAJ were prepared and characterized by DSC (differential exploratory calorimetry) to evaluate collagen denaturation temperature, SEM (scanning electron microscopy), ethanol immersion porosity assays, saline phosphate buffer (PBS) absorption kinetics, collagenase degradation assays, antimicrobial activity and cytotoxicity assays. Collagen was characterized by DSC and infrared spectroscopy (FTIR), nanohydroxyapatite by energy-dispersive X-ray spectroscopy (EDX) to evaluate the $\mathrm{Ca} / \mathrm{P}$ ratio, by SEM, by X-ray diffraction (XRD), FTIR and cytotoxicity assays. The extracts were analyzed by FTIR, cytotoxicity assay and total flavonoids concentration by ultraviolet-visible spectroscopy (Uv-vis). It was observed that the grape seed extract presented the lowest minimum bactericidal concentration, being $250 \mu \mathrm{g} \mathrm{mL}^{-1}$ and the three extracts acted as biopolymer crosslinking agents, increasing its enzymatic resistance and thermal stability. Hydroxyapatite was obtained within the nanometer scale and $\mathrm{Ca} / \mathrm{P}$ ratio equal to $1.60 \pm 0.03$. Only $\mathrm{CR}$ scaffold presented antimicrobial activity and all extracts showed cytotoxicity at the concentrations tested, while nanohydroxyapatite increased cell viability. The scaffolds presented porosity and pore size appropriate for bone growth. After $24 \mathrm{~h}$ of incubation, they presented high cell viability (more than $70 \%$ ) and after $48 \mathrm{~h}$ the CR, CnHAP, CnHAR and CnHAJ presented cytotoxicity. It can be concluded that only matrices $\mathrm{C}, \mathrm{CP}, \mathrm{CJ}$ and $\mathrm{CnHA}$ could be used as biomaterial for bone tissue regeneration and for the in vivo tests step.
\end{abstract}

Keywords: collagen, nanohydroxyapatite, flavonoid, bone regeneration. 


\section{Lista de Figuras}

Figura 1: Esquema da anatomia do osso longo

Figura 2: Esquema da reconstrução óssea: a) formação do hematoma; b) calo mole; c) calo duro; d) remodelação óssea

Figura 3: Representação da a) estrutura cristalina; b) estrutura hexagonal; c) célula primitiva da hidroxiapatita

Figura 4: Representação esquemática a) cadeias a1 e a2; b) tropocolágeno representado pela hélice tripla; c) organização estrutural das moléculas de acordo com o modelo de Smith; d) união de microfibrilas formando uma fibrila.

Figura 5: Representação da hidrólise alcalina dos grupos carboxiamidas dos resíduos de Asn e Gln 31

Figura 6: Representação básica da estrutura dos flavonoides 33

Figura 7: a) fotografia da uva; b) representação da estrutura de uma proantocianidina ...... 35

Figura 8: a) fotografia da romã; estrutura da b) catequina (2R, 3S); c) epicatequina (2R, 3R); d) epigalocatequina $(2 R, 3 R)$

Figura 9: a) fotografia da jabuticaba; estrutura da b) delfinidina; c) malvidina; d) peondina37 Figura 10: Representação do diâmetro de Feret: $d_{H}$ ) horizontal e $d_{V}$ ) vertical das particulas de $\mathrm{nHA}$ 45

Figura 11: Representação do diâmetro de Martin 46

Figura 12: Representação de: a) poros abertos ou poros da superficie; b) poros fechados ou internos; c) poros interconectados; d) superficie rugosa; e) superficie compacta ou lisa..... 46

Figura 13: Fotografia do Efeito Tyndall da suspensão de hidroxiapatita .54

Figura 14: Fotografia dos extratos de: a) semente de uva; b) casca de romã; c) casca de jabuticaba

Figura 15: Fotografia digital das matrizes: a) $\mathrm{C}$, b) $\mathrm{CP}$, c) $\mathrm{CR}$, d) $\mathrm{CJ}$, e) $\mathrm{CnHA}$, f) $\mathrm{CnHAP}$, g) CnHAR e h) CnHAJ .55

Figura 16: Espectro FTIR-ATR do colágeno .56

Figura 17: Espectro FTIR do fosfato de cálcio 57

Figura 18: Espectros FTIR de (-) extrato de casca de jabuticaba, $(-)$ extrato de casca de romã e (-) extrato de semente de uva. 58

Figura 19: Curva de calibração de quercetina 59 
Figura 20: Complexação do flavonoide quercetina pelo $\mathrm{AlCl}_{3}$, gerando o complexo quercetina-Al ${ }^{3+}$ 60

Figura 21: Espectro EDX do fosfato de cálcio 61

Figura 22: Difratograma da (A) hidroxiapatita sintetizada com picos de $(\bullet) \mathrm{NaCl}$ e $(\bullet) \mathrm{KCl}$, e (B) hidroxiapatita JCPDS 9-0432. 62

Figura 23: Fotomicrografia por MEV da hidroxiapatita 65

Figura 24: Histograma da distribuição do tamanho dos diâmetros dos aglomerados na nanohidroxiapatita: $(\mathbf{A})$ horizontais e $(\mathbf{B})$ verticais 66

Figura 25: Matriz C: A) Fotomicrografia por MEV da superfície; B) Histograma da secção transversal; C) Fotomicrografia por MEV da secção transversal. 68

Figura 26: Matriz CP: A) Histograma dos poros da superficie; B) Fotomicrografia por MEV da superficie; C) Histograma dos poros da secção transversal; D) Fotomicrografia por MEV da secção transversal.

Figura 27: Matriz CR: A) Histograma dos poros da superficie; B) Fotomicrografia por MEV da superficie; C) Histograma dos poros da secção transversal; D) Fotomicrografia por MEV da secção transversal. 70

Figura 28: Matriz CJ: A) Histograma dos poros da superficie; B) Fotomicrografia por MEV da superficie; C) Histograma dos poros da secção transversal; D) Fotomicrografia por MEV da secção transversal. 70

Figura 29: Matriz CnHA: A) Histograma dos poros da superficie; B) Fotomicrografia por MEV da superficie; C) Histograma dos poros da secção transversal; D) Fotomicrografia por MEV da secção transversal..

Figura 30: Matriz CnHAP: A) Histograma dos poros da superficie; B) Fotomicrografia por MEV da superficie; C) Histograma dos poros da secção transversal; D) Fotomicrografia por MEV da secção transversal.....

Figura 31: Matriz CnHAR: A) Fotomicrografia por MEV da superfície; B) Histograma da secção transversal; C) Fotomicrografia por MEV da secção transversal. 73

Figura 32: Matriz CnHAJ: A) Fotomicrografia por MEV da superfície; B) Histograma da secção transversal; C) Fotomicrografia por MEV da secção transversal. 73

Figura 33: Porcentagem de absorção das matrizes $\mathrm{C}(\square)$ e $\mathrm{CnHA}(\bullet)$ .78

Figura 34: Porcentagem de absorção das matrizes $\mathrm{C}(\square)$; CP $(\bigcirc)$, CR $(\triangle)$; CJ $(\diamond)$ .79

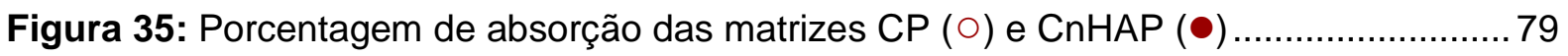

Figura 36: Porcentagem de absorção das matrizes $\mathrm{CR}(\triangle)$ e $\mathrm{CnHAR}(\triangle) \ldots$ 80 
Figura 37: Porcentagem de absorção das matrizes CJ $(\diamond)$ e $\mathrm{CnHAJ}(\diamond)$

Figura 38: Porcentagem de absorção das matrizes $\operatorname{CnHA}(\boldsymbol{\bullet})$; $\operatorname{CnHAP}(\bullet)$; $\operatorname{CnHAR}(\triangle)$; CnHAJ $(\diamond)$

Figura 39: Fotomicrografia por MEV da superficie das matrizes degradadas por 6h: A) C; B) CnHA; C) CP; D) CnHAP; E) CR; F) CnHAR; G) CJ; H) CnHAJ. 84

Figura 40: Fotografia digital da determinação da CIM da linhagem de $S$. aureus, sendo: J) extrato de casca de jabuticaba; R) extrato de casca de romã; P) extrato semente de uva; C+) controle positivo; $\mathbf{C}$-) controle negativo 86

Figura 41: Fotografia do A) halo do antibiotico; B) controle positivo 87

Figura 42: Fotografia do ensaio de disco difusão das matrizes A) C; B) CP; C) CR; D) CJ;

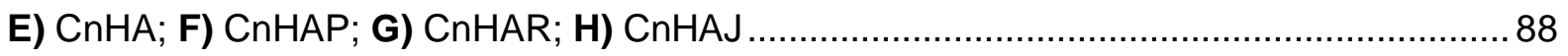

Figura 43: Fotografia da placa de microdiluição para o ensaio de citotoxicidade dos: P) extrato de semente de uva; R) extrato de casca de romã; J) extrato de casca de jabuticaba; nHA) nanohidroxiapatita; onde $\mathbf{C +}$ ) controle positivo; $\mathbf{C}$-) controle negativo; B) branco 90

Figura 44: Porcentagem de viabilidade celular em: (A) 24h e (B) 48h, para ( $\nabla$ ) nHA; (匹) P; (•) R; ( $\mathbf{\Delta}) \mathrm{J}$.

Figura 45: Fotografia da placa de microdiluição do ensaio de citotoxicidade das matrizes, na qual B) branco; $\mathbf{C}$-) controle negativo; $\mathbf{C +}$ ) controle positivo; $\mathbf{C C}$ ) controle de células. ...93 Figura 46: Porcentagem de viabilidade celular das matrizes em (A) 24h e (B) 48h 94 


\section{Lista de Tabelas}

Tabela 1: Denominação das matrizes e suas respectivas composições. .............................. 41

Tabela 2: Bandas no FTIR observadas nos espectros dos extratos .....................................58

Tabela 3: Comparação entre os valores de $2 \theta$ da hidroxiapatita sintetizada com os obtidos da

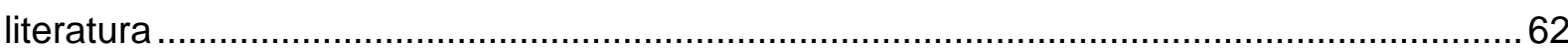

Tabela 4: Valores da temperatura de desnaturação $\left(\mathrm{Td}^{\circ} \mathrm{C}\right)$ para as matrizes .....................64

Tabela 5: Valores do tamanho médio, do maior e do menor poro da superficie das fotomicrografias por MEV das matrizes ................................................................................ 67

Tabela 6: Valores do Tamanho médio, do menor e do maior poro interno (canais) das

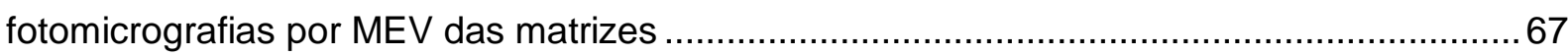

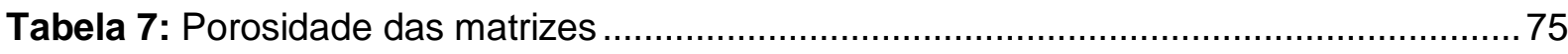

Tabela 8: Porcentagem de absorção de tampão fosfato salino ...........................................77

Tabela 9: Porcentagem de degradação das matrizes em diferentes tempos ........................82

Tabela 10: Comparação entre os tamanhos de poro da superficie das matrizes não

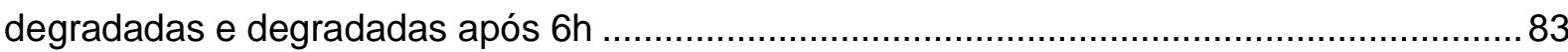

Tabela 11: Valores de CIM e CBM dos diferentes extratos sobre S. aureus........................86

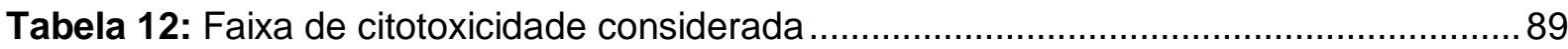




\section{Lista de Abreviaturas}

ANOVA - Análise de variância

Asn - Asparagina

ATCC - American Type Culture Collection

ATR - Refletância total atenuada

C - Matriz de colágeno

CAQI - Central de Análises Químicas

CB - Centro de Biotecnologia

CBM - Concentração bactericida mínima

CIM - Concentração inibitória mínima

CJ - Matriz de colágeno + extrato de casca de jabuticaba

CLSI - Clinical and Laboratory Standards Institute

CnHA - Matriz de colágeno + nanohidroxiapatita

CnHAJ - Matriz de colágeno + nanohidroxiapatita + extrato de casca de jabuticaba

CnHAP - Matriz de colágeno + nanohidroxiapatita + extrato de semente de uva

CnHAR - Matriz de colágeno + nanohidroxiapatita + extrato de casca de romã

CP - Matriz de colágeno + extrato de semente de uva

CR - Matriz de colágeno + extrato de casca de romã

CTAB - Brometo de cetrimônio

CTR - Centro de Tecnologia das Radiações

d6h - degradadas por $6 \mathrm{~h}$

$\mathbf{d}_{\mathbf{H}}$ - Diâmetro horizontal

DMEM - Dulbecco's Modified Eagle's Medium

DRX - Difração de Raios-X

DSC - Calorimetria exploratória diferencial

$\mathbf{d}_{\mathrm{v}}$ - Diâmetro vertical

EDTA - ácido etilenodiamino tetra-acético

EDX - Energia dispersiva de raios $\mathrm{X}$

FTIR - Infravermelho com transformada de Fourier

Gln - Glutamina 
Gly - Glicina

HA - hidroxiapatita

HtodL - Hospital Estadual de Traumatologia e Ortopedia Dona Lindu

Ile - isoleucina

Into - Instituto Nacional de Traumatologia e Ortopedia Jamil Haddad

Ipen - Instituto de Pesquisa Energéticas e Nucleares

IUPAC - International Union of Pure and Applied Chemistry

$\mathbf{J}$ - Extrato de casca de jabuticaba

Leu - Leucina

MEV - Microscopia eletrônica de varredura

MHB - Ágar Müeller Hinton

MTS - (3-(4,5-dimetiltiazol-2-il)-5-(3-carboximetoxifenil)-2-(4-sulfofenil)-2H-tetrazólio)

MTT - brometo de 3-(4,5-dimetiltiazol-2-il)-2,5-difenil-tetrazólio)

nHA - nanohidroxiapatita

$\mathbf{P}$ - Extrato de semente de uva

PBS - Tampão fosfato salino

PLGA - Poli(ácido lático-co-ácido glicólico)

Pro - Prolina

$\mathbf{R}$ - Extrato de casca de romã

Td - Temperatura de desnaturação

TSYEA - Ágar extrato de levedura triptona de soja

UFC - Unidades formadoras de colônia

UV-Vis - Espectroscopia no ultravioleta visível 


\section{SUMÁRIO}

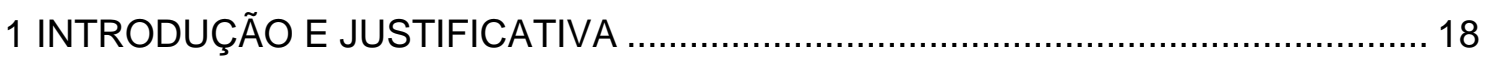

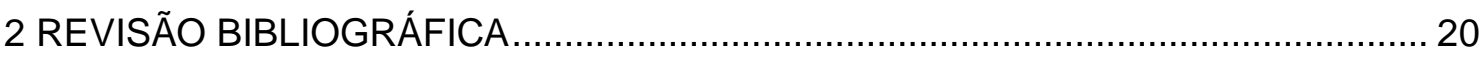

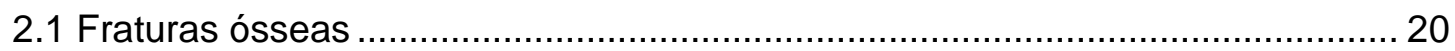

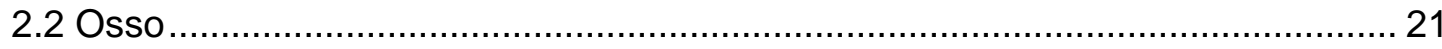

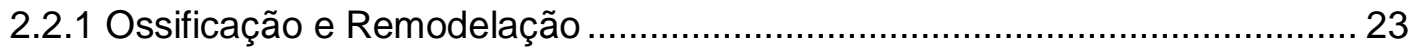

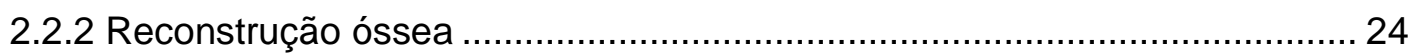

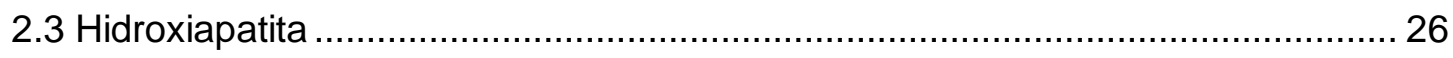

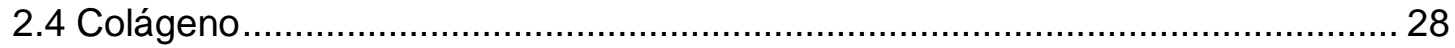

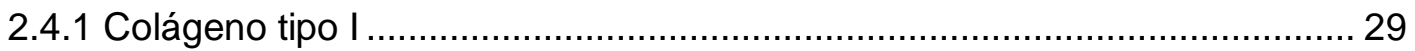

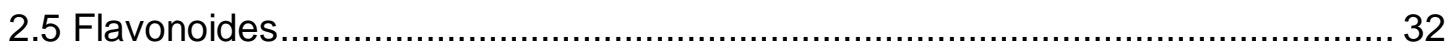

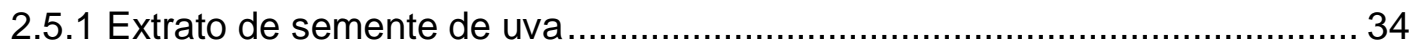

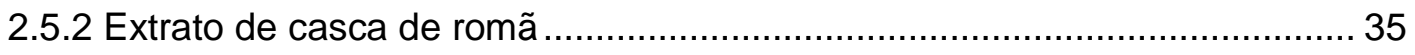

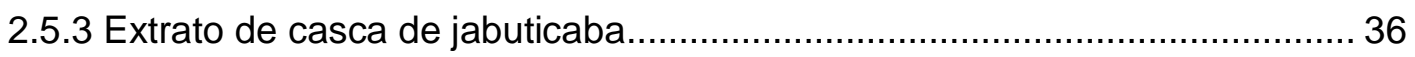

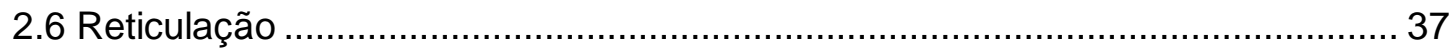

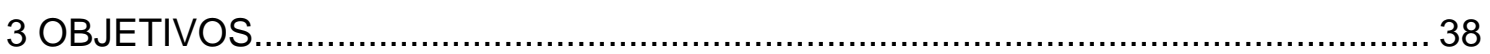

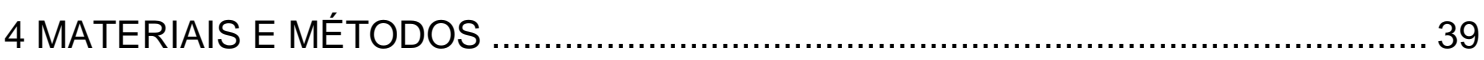

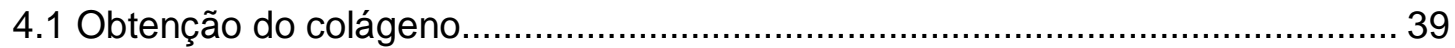

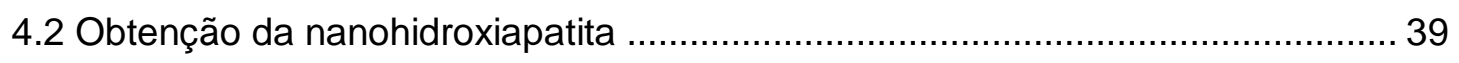

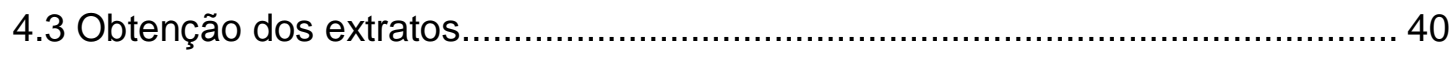

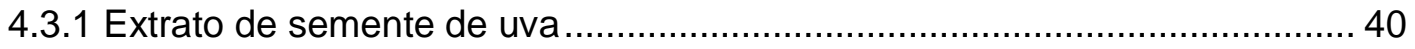

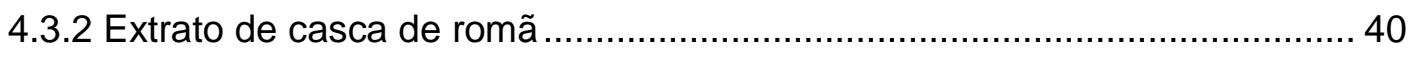

4.3.3 Extrato de casca de jabuticaba........................................................... 40

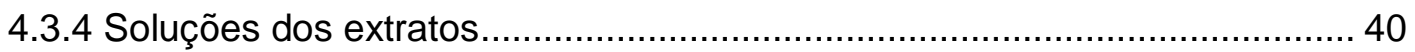

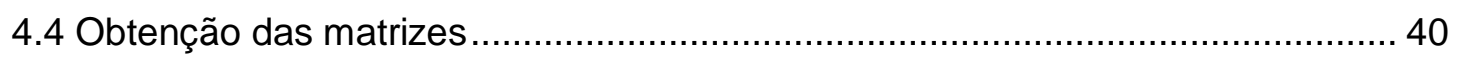

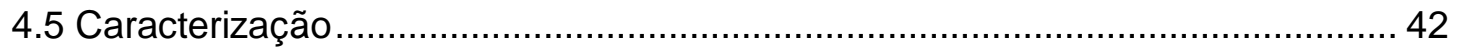

4.5.1 Espectroscopia na região do infravermelho (FTIR) .................................. 42

4.5.2 Análise da concentração total de flavonoides ........................................... 43

4.5.3 Espectroscopia por energia dispersiva de raios X (EDX) .......................... 43

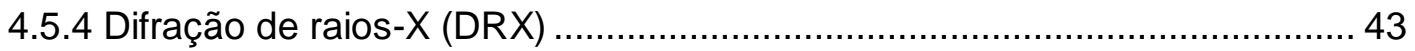

4.5.5 Calorimetria exploratória diferencial (DSC) ............................................. 44 
4.5.6 Microscopia eletrônica de varredura (MEV) …............................................. 44

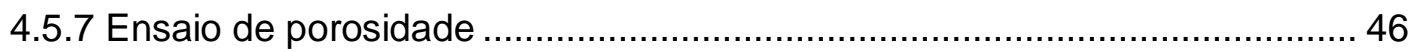

4.5.8 Cinética de absorção em PBS .................................................................. 47

4.5.9 Estabilidade biológica in vitro (colagenase) ............................................ 47

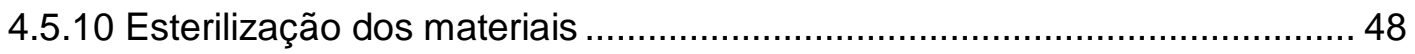

4.5.11 Ensaios de atividade antimicrobiana .................................................... 48

(a) Obtenção das linhagens bacterianas ....................................................... 48

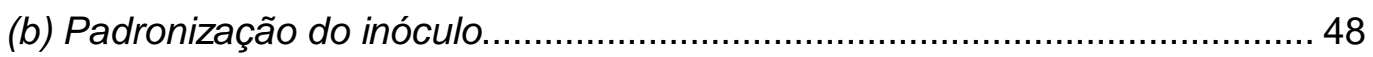

(c) Testes de atividade antimicrobiana dos extratos ....................................... 48

(d) Testes de atividade antimicrobiana das matrizes ...................................... 50

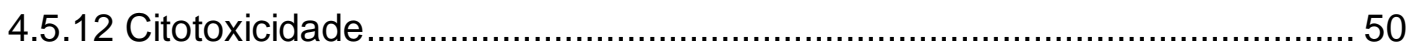

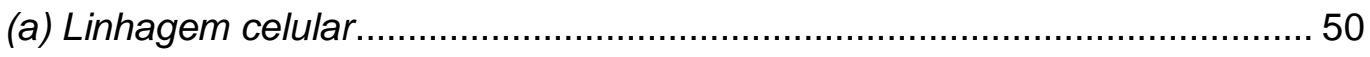

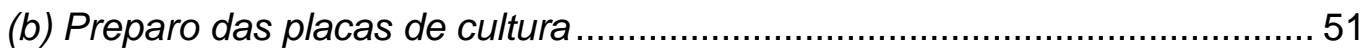

(c) Preparo das soluções dos extratos vegetais e nanohidroxiapatita................52

(d) Preparo do extrato das matrizes............................................................. 52

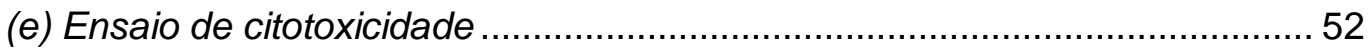

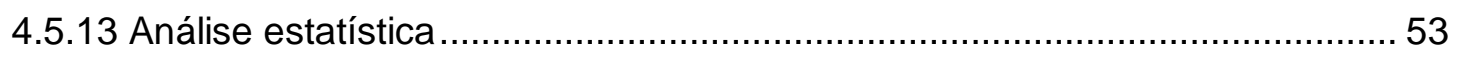

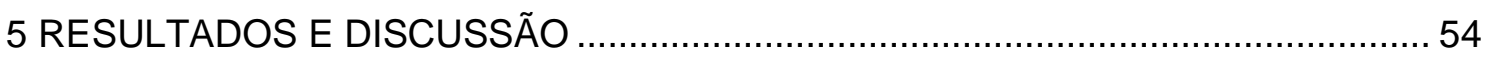

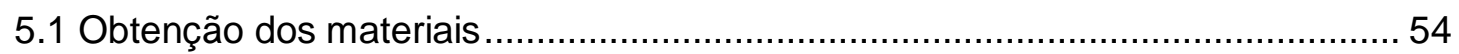

5.1.1 Obtenção da nanohidroxiapatita....................................................... 54

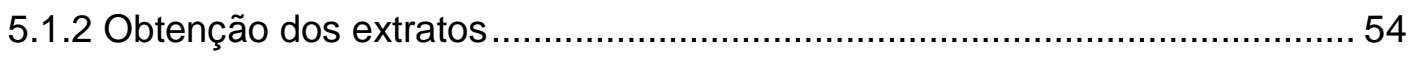

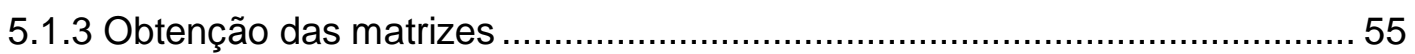

5.2 Espectroscopia no infravermelho (FTIR) ……....................................... 55

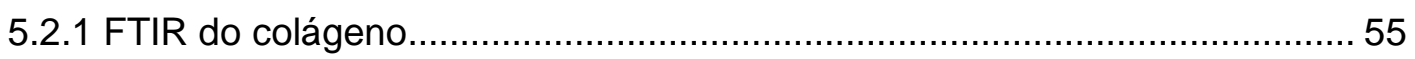

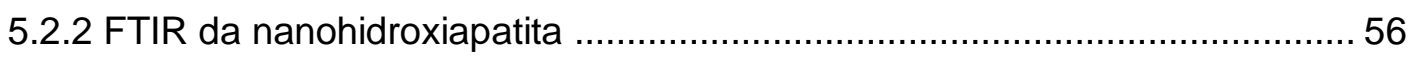

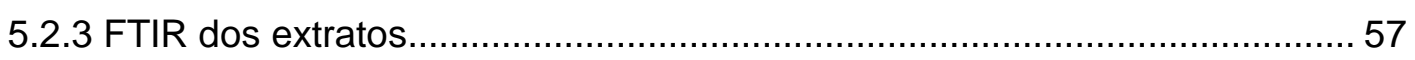

5.3 Análise da concentração de flavonoides totais ................................................. 59

5.4 Espectroscopia por energia dispersiva de raios X (EDX) .................................6 60

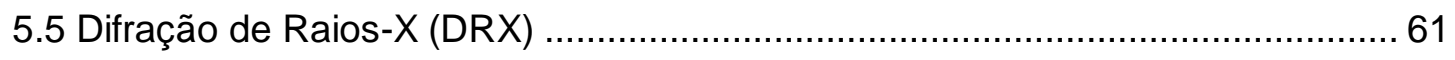

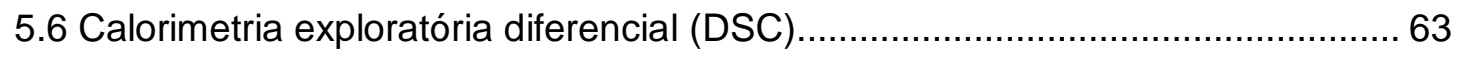

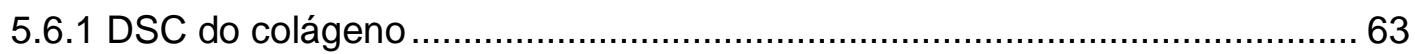

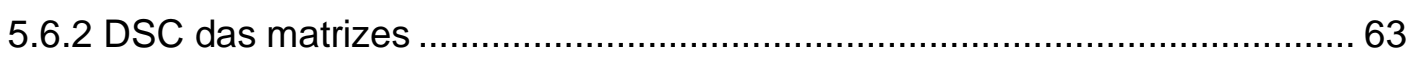


5.7 Microscopia eletrônica de varredura (MEV) …................................................ 64

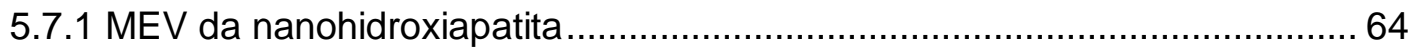

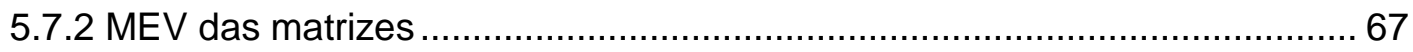

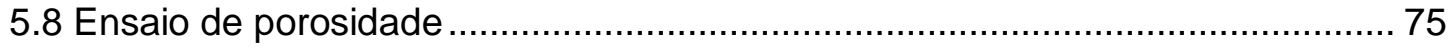

5.9 Cinética de absorção em PBS ...................................................................... 76

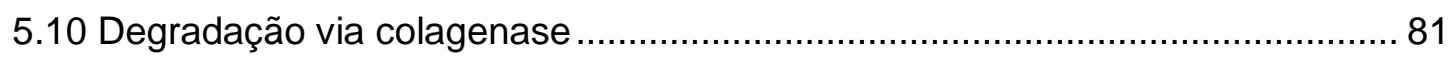

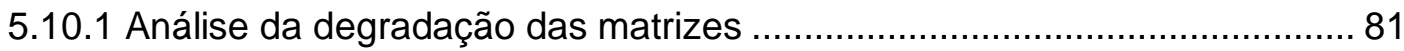

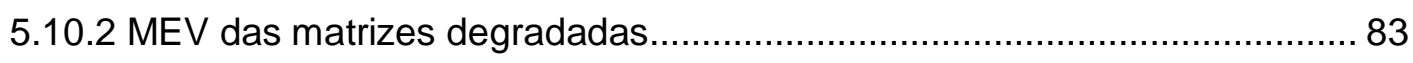

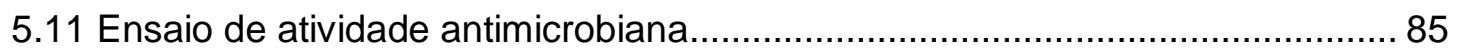

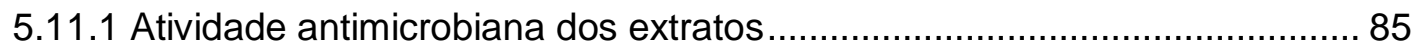

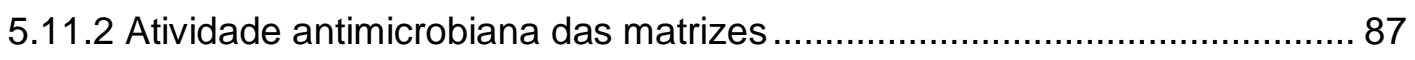

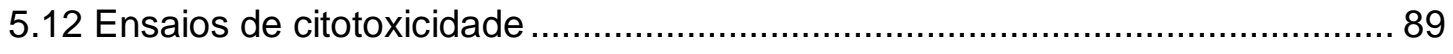

5.12.1 Citotoxicidade dos extratos vegetais e da nanohidroxiapatita ................... 89

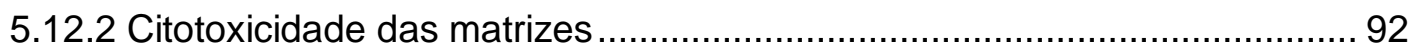

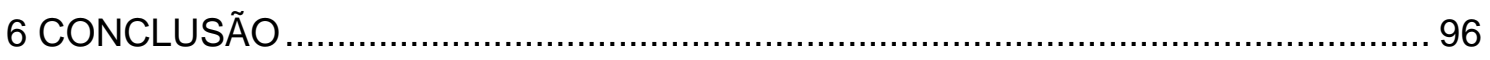

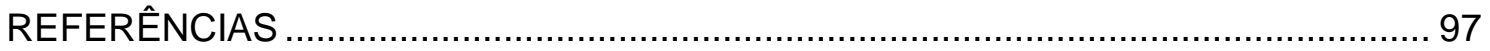

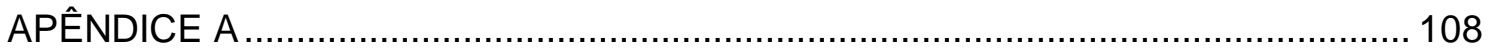




\section{INTRODUÇÃO E JUSTIFICATIVA}

No Brasil, o Instituto Nacional de Traumatologia e Ortopedia Jamil Haddad (Into), localizado na cidade do Rio de Janeiro, realizou em 2015 mais de 9,1 mil cirurgias ortopédicas, sendo a maior unidade brasileira a realizar esse tipo de cirurgia. Em segundo lugar a realizar cirurgias em osso encontra-se o Hospital Estadual de Traumatologia e Ortopedia Dona Lindu (Htodl), situado na cidade de Paraíba do Sul - RJ, que em 2016 realizou 3,7 mil cirurgias (Villela, 2017).

Em cirurgias ortopédicas muitas vezes bastam o reposicionamento do osso fraturado em posição anatômica (ou estável) seguido de imobilização, para uma reparação óssea efetiva. Entretanto, há fraturas mais críticas que necessitam do auxílio de biomateriais para manter o osso em posição anatômica ou que precisam ser adicionados para auxiliar na reparação óssea completa.

Desde a década de 60, diversos biomateriais têm sido desenvolvidos para serem utilizados em cirurgia ortopédica, como fixadores internos, fixadores externos, parafusos de cerâmicas e enxertos ósseos. Porém, os tratamentos convencionais trazem desvantagens associadas à baixa biocompatibilidade do material e no caso de enxertos, à morbidade de um local doador e a escassez de auto-enxerto e aloenxerto, sendo que este último pode trazer o risco de transmissão de doenças e infecções (Yu et al., 2015).

A engenharia tecidual é um campo de pesquisa interdisciplinar que visa a compreensão da estrutura e função dos tecidos e o desenvolvimento de substitutos biológicos para restaurar, manter, aumentar ou melhorar a função de órgãos ou tecidos lesados (Lanza et al., 2007). Ela combina o uso de células, engenharia de materiais e fatores físico-químicos para eliminar as desvantagens dos tratamentos clínicos convencionais (Khademhosseini e Langer, 2016).

Dentro da engenharia tecidual, uma das áreas de grande interesse é a engenharia de tecidos ósseos, que busca o desenvolvimento de matrizes (arcabouços, andaimes ou scaffolds) para substituir ou reparar o tecido ósseo. Essas matrizes precisam possibilitar a introdução de fármacos, fatores de crescimento ou células (osteoblastos ou condrócitos) em sua estrutura, além de estimular o crescimento de tecido imaturo (ou primário) e possibilitar a formação de tecido permanente assim como sua remodelação (Velasco et al., 2015; Roseti et al., 2017). 
A utilização de biomateriais semelhantes ao tecido ósseo natural possibilita a fabricação de matrizes com melhor biocompatibilidade e biodegradabilidade, o que reduz a necessidade de demais cirurgias e facilita o processo pós-operatório.

O tecido ósseo natural é formado por uma parte orgânica composta principalmente de colágeno tipo I, uma proteína fibrosa muito presente no reino animal e uma parte inorgânica formada principalmente por fosfato de cálcio na forma de hidroxiapatita (Ryan et al., 2015; Montanari, 2016).

O colágeno apresenta propriedades hemostáticas e é capaz de estimular e orientar a formação de tecido natural. Ele é responsável pelas propriedades físicas dos tecidos que formam a pele, tendões, intestinos, ossos e dentes (Pontel e Boabaid, 2019). A hidroxiapatita é uma biocerâmica que, assim como o colágeno, pode estimular e orientar a formação de tecido ósseo. Em sua forma nanoparticulada ainda possibilita melhor sorção de proteínas e adesão celular, o que acelera a reparação óssea (Pearson et al., 2019).

Graças a essas propriedades, a utilização desses dois biomateriais para produção de matrizes para reconstrução de tecido ósseo vem sendo muito estudada nas últimas décadas (Roseti et al., 2017).

Para se melhorar as propriedades clinicas e mecânicas dessas matrizes, ainda pode-se incorporar fármacos ou moléculas com propriedades biológicas de interesse. Essa incorporação direta no material traz vantagens clinicas, já que tecido ósseo é limitado em circulação sanguínea, o que reduz o efeito terapêutico de fármacos administrados de modo convencional.

Flavonoides são um grupo de compostos polifenólicos muito conhecidos por dar cor amarelada ou avermelhada a frutos. Esses polifenóis apresentam grande capacidade antioxidante, sendo capazes de eliminar radicais livres no corpo humano, além de ter propriedades bactericidas, antifúngicas, anti-inflamatórias, cardioprotetoras e antivirais. (Cho et al., 2009; Crozier et al., 2009; Kruger, 2014). Outra característica dos flavonoides é que eles podem atuar como agente reticulante do colágeno, podendo melhorar a resistência mecânica e térmica do biopolímero.

Sendo assim, esse trabalho busca o desenvolvimento de materiais biocompatíveis formados por colágeno, hidroxiapatita e extratos naturais que possam ajudar na regeneração óssea, acelerando na reconstrução do osso e reduzindo tempo de tratamento. 


\section{REVISÃO BIBLIOGRÁFICA}

\subsection{Fraturas ósseas}

O esqueleto humano é um conjunto de ossos e cartilagens que se interligam formando a estrutura do corpo humano, que apresenta a função de dar forma (conformação) e sustentação do corpo. Além disso, apresenta funções de proteção de órgãos, armazenamento de íons, minerais e triglicerídeos, auxilio na movimentação do corpo e membros e produção de células sanguíneas (Dangelo e Fattini, 2007; Tortora e Derrickson, 2017).

Fraturas no sistema esquelético correspondem a uma descontinuidade no osso, podendo comprometer uma ou mais funções do esqueleto. Elas podem ser patológicas, onde há um enfraquecimento da estrutura óssea por alguma infecção ou doença como a osteoporose, ou por algum trauma (Tortora e Derrickson, 2017). As fraturas ósseas também podem ser classificadas pelo rompimento parcial ou total do osso, sendo definidas como fraturas parciais ou completas, respectivamente. Além disso, podem ser classificadas pela ruptura ou não da pele, sendo chamadas de fratura fechada (simples) ou aberta (composta ou exposta) (Tortora e Derrickson).

No Brasil, diversas pesquisas vêm sendo feitas para se buscar o perfil de pessoas que mais sofrem fraturas ósseas. Sabendo-se a faixa etária, sexo e motivos das lesões, pode-se estabelecer uma postura preventiva a esses acidentes ou podese desenvolver medicamentos ou substitutos ósseos adequados. Arruda et al. (2009) realizaram uma pesquisa para definir o perfil epidemiológico dos pacientes atendidos no Hospital Santa Marcelina em São Paulo, entre setembro de 2005 a março de 2007. Concluíram que as maiores ocorrências de acidentes com fraturas expostas ocorrem em jovens do sexo masculino, em decorrência de condições inadequadas de trabalho.

De acordo com Pinheiro et al. (2010), que fizeram um estudo com 2.420 indivíduos acima de 40 anos, das cinco regiões do país, não há diferença significativa da prevalência de fraturas por baixo impacto nem da frequência ou relevância de fatores de risco entre as cinco regiões do Brasil. Resende et al (2017) avaliaram o perfil de idosos com fratura óssea na Clínica Integrada de Fisioterapia da Universidade de Itaúna, Minas Gerais, entre fevereiro e março de 2016. Constataram que a maior ocorrência de fraturas ósseas ocorre em idosas do sexo feminino, devido à baixa mineralização óssea em decorrências de alterações hormonais da menopausa. 


\subsection{Osso}

Os ossos são cada uma das partes formadoras do tecido rígido que forma o esqueleto. Estes são altamente dinâmicos, sofrendo constantemente alterações e regeneração. São formados por duas partes distintas, sendo uma inorgânica, correspondendo de $70 \%$ a $60 \%$ do peso do osso, e outra orgânica, correspondendo a $30 \%$ a $20 \%$ do peso (Rodrigues, 2012; Polo-Corrales et al., 2014). Cerca de $2 \%$ do peso do osso são referentes a componentes celulares, responsáveis pela regeneração e nutrição do osso e em torno de $10 \%$ de seu peso total é água (Wojnar et al., 2010).

A parte inorgânica é formada por cerâmicas e metais, sendo que a maior parte (95\%) é composta por fosfato de cálcio na forma da hidroxiapatita, biocerâmica de fórmula $\mathrm{Ca}_{5}\left(\mathrm{PO}_{4}\right)_{3} \mathrm{OH}$. Outros componentes como carbonato de cálcio bicarbonato de cálcio, citrato, magnésio, potássio e outros metais são encontrados em menores quantidades (Wojnar et al., 2010; Alvarez e Nakajima, 2009).

A parte orgânica é composta principalmente por colágeno tipo I, a proteína mais abundante do corpo, mas também há a presença de pequenas quantidades de proteoglicanas de baixa massa molar, glicosaminoglicanos como o ácido hialurônico e glicoproteínas de adesão. O componente celular do osso é composto principalmente pelas células osteoprogenitoras, osteoblastos, osteócitos e osteoclastos (Montanari, 2016).

A composição química do osso, assim como a estrutura cristalina, tamanho de partículas, quantidade de células e localização dos metais e proteínas varia em função da idade do animal. Outro fator importante é a velocidade com que o osso se regenera, ou seja, o tempo decorrido entre a deposição inicial dos cristais de apatita e sua remoção (reabsorção) pelo tecido (Rey et al., 2009).

Os ossos também apresentam diferenças morfológicas macroscópicas, no qual o mesmo osso é composto por duas partes, sendo uma compacta e a outra esponjosa, conforme mostra a Figura 1. Além disso, apresentam espaços que incluem a cavidade da medula óssea, lacunas e canais vasculares como os canais de Havers e canais de Volkmann (Montanari, 2016).

A parte esponjosa do osso, também conhecido como osso trabecular, é encontrada em seu interior e é constituída por uma rede de trabéculas interligadas, que apresentam grande área superficial e possibilitam maior função metabólica que o 
osso compacto, que por sua vez também é denominado como osso cortical. Essa parte do osso é a periférica, servindo como um revestimento resistente a deformações. Ela apresenta estrutura mais densa que o osso esponjoso e é responsável principalmente pela resistência física, sendo resistente a compressão, torção e flexão (Polo-Corrales et al., 2014; Montanari, 2016).

Figura 1: Esquema da anatomia do osso longo

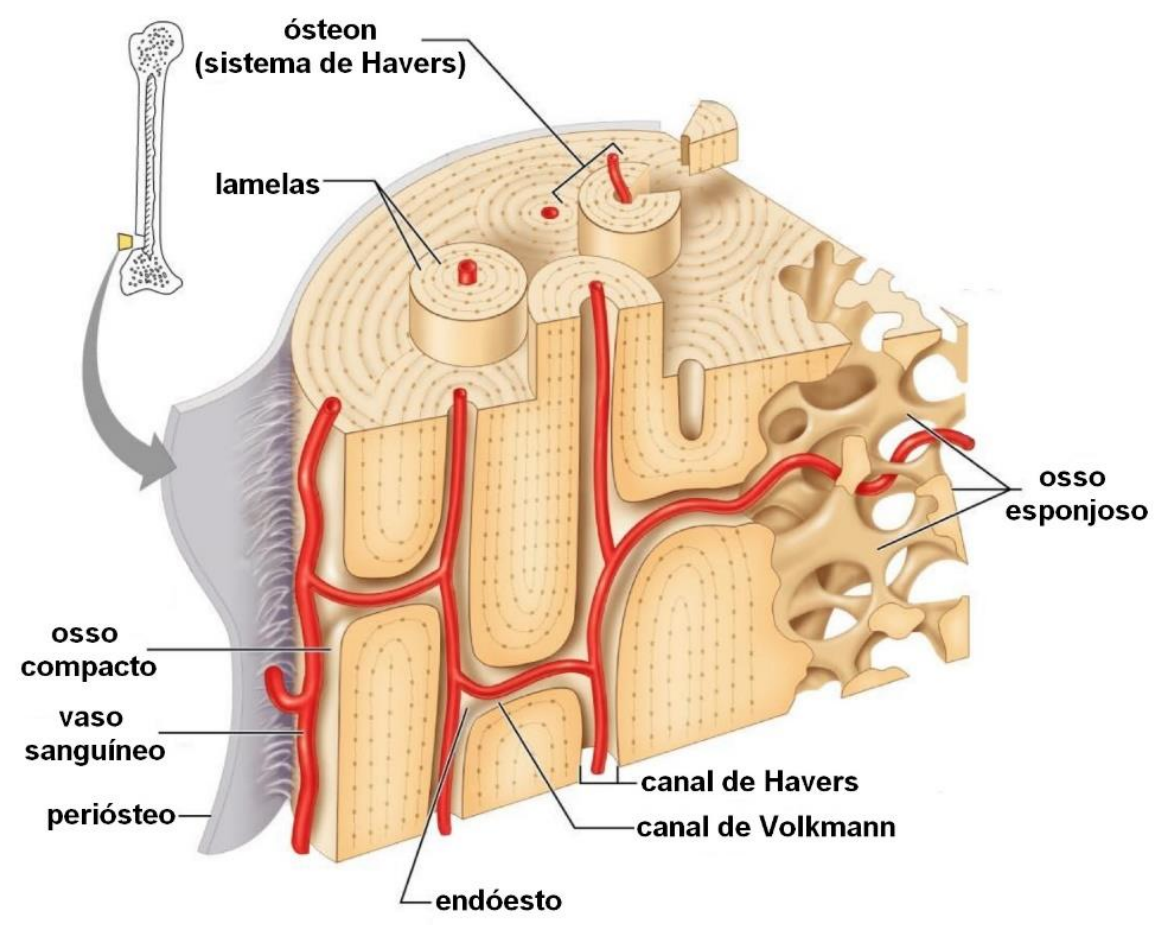

Fonte: Adaptado de Maried (2007)

O tecido ósseo também pode ser chamado de tecido ósseo primário ou secundário, em decorrência da disposição das fibras de colágeno e das células presentes no tecido.

O tecido ósseo primário ou imaturo é o primeiro a se formar independentemente do tipo de ossificação que estiver ocorrendo. Ele é temporário, apresentando menor quantidade de minerais quando comparado ao tecido secundário e suas fibras de colágeno se dispõem de maneira irregular, sem orientação definida. O tecido ósseo secundário, também conhecido como maduro ou lamelar, apresenta maior quantidade de minerais e as fibras de colágeno são organizadas em forma de lamelas (Junqueira e Carneiro, 2013). 


\subsubsection{Ossificação e Remodelação}

A histogênese óssea ou processo de ossificação pode ocorrer de duas formas distintas, podendo ser intramembranosa ou endocondral. Cada um desses processos forma um tipo de osso do esqueleto, e em ambos os casos, é formado primeiro o tecido ósseo primeiro que posteriormente é substituído pelo tecido ósseo secundário.

O processo de ossificação intramembranosa ocorre no interior de membranas de tecido conjuntivo, local chamado de centro de ossificação primária. Essa ossificação forma principalmente os ossos chatos, incluindo a abóbada do crânio, a maior parte do esqueleto facial superior, partes da mandíbula, clavícula e pelve (Manolagas et al., 2018).

No centro de ossificação primaria, células mesenquimais se diferenciam em células osteoprogenitoras, que se diferenciam em osteoblastos, células responsáveis pela síntese do osteoide, que é a parte orgânica da matriz óssea (ou seja, matriz não mineralizada).

Com a síntese do osteoide, começa a mineralização da matriz óssea, o que acaba confinando alguns osteoblastos, que posteriormente se diferenciam em osteócitos presos na matriz. Esses osteócitos são as células responsáveis pela manutenção do osso e também por dar aspecto esponjo ao osso primário, permitindo a futura vascularização do osso (Manolagas et al., 2018).

Os núcleos de ossificação que estão se mineralizando começam a se unir formando assim os ossos chatos. A parte da membrana conjuntiva que não sofre ossificação passa a constituir o endósteo e o periósteo, tecidos conjuntivos situados na periferia do osso e que ajudam na manutenção e em sua reconstrução em caso de fraturas (Manolagas et al., 2018; Junqueira e Carneiro, 2013). O processo de ossificação endocondral ocorre através de um molde de cartilagem semelhante ao osso que irá se formar, só que de tamanho menor. Esse processo é responsável por formar os ossos curtos e longos, encontrados principalmente nos membros superiores e inferiores do corpo humano (Junqueira e Carneiro, 2013; Montanari, 2016).

Durante a ossificação, a cartilagem que serve de molde para o novo osso sofre redução de sua massa, hipertrofia de suas células denominadas condrócitos, e posterior morte celular por apoptose. As cavidades que antes eram ocupadas pelos condrócitos são invadidas por capilares sanguíneos e células osteoprogenitoras 
advindas do tecido conjuntivo adjacente. Essas células sofrem diferenciação e se tornam osteoblastos, que depositam matriz óssea onde antes era cartilagem.

Essas duas formas de ossificação são responsáveis pela formação do osso desde a fase embrionária até a adulta, quando ocorrem fraturas ósseas. Sabe-se que o tecido ósseo é um tecido dinâmico, que está sempre em processo de troca e manutenção (Langdahl et al., 2016; Manolagas et al., 2018).

O processo chamado de modelagem óssea ocorre durante 0 desenvolvimento e crescimento até a fase adulta. Após esse período, durante toda a fase adulta, ocorre o processo de remodelação óssea, que é a renovação gradativa dos ossos (Andia et al., 2006).

Esse processo de remodelação óssea ocorre em quatro etapas: a primeira é a de ativação, quando os osteoclastos, células especializadas em reabsorção de outras células e de matriz extracelular, são recrutadas; a segunda etapa é a de reabsorção na qual os osteoclastos reabsorvem parte do osso; a terceira é a reversa, na qual os osteoclastos sofrem apoptose e os osteoblastos são recrutados; a quarta e última é a de formação, na qual os osteoblastos formam uma nova matriz que será mineralizada posteriormente (Langdahl et al. 2016; Andia et al. 2006).

\subsubsection{Reconstrução óssea}

No momento que ocorre a fratura óssea devido à alguma patologia ou trauma, ocorre também o rompimento de vasos sanguíneos e por consequência, do endotélio. Com isso, ocorre a formação do hematoma (Figura 2a) e se inicia o processo de hemostasia primária, na qual mecanismos locais iniciam a vasoconstrição do local lesado, que reduz o fluxo sanguíneo evitando a perda e sangue (Hess et al., 2008; Sundaram e Keenan, 2010).

A hemostasia secundária é o processo de coagulação, na qual a trombina converte uma proteína solúvel do plasma, o fibrinogênio, em um polímero insolúvel chamado de fibrina, que serve e barreira física impedindo o sangramento (Hess et al., 2008; Sundaram e Keenan, 2010; Pereira et al., 2019).

O osso fraturado e seus fragmentos devem ser colocados em posição anatômica ou dita aceitável, para depois serem imobilizados e a reconstrução óssea ser a mais efetiva possível, sem deformidades ou encadeamento de novas lesões devido ao mau posicionamento do osso (Ruaro, 2004). 
O reparo ósseo tem início com a remoção de coágulos sanguíneos, células mortas e restos desnutridos de matriz extracelular por macrófagos. Posteriormente, o periósteo e o endósteo próximos a área da fratura iniciam intensa proliferação de células osteoprogenitoras, formando assim um tecido rico que iniciará a reparação da lesão. Essas células envolvem as extremidades do osso rompido, formando um colar conjuntivo também chamado de calo mole ou calo fibrocartilaginoso (Figura 2b) (Junqueira e Carneiro, 2013).

Nesse colar, inicia-se a formação do tecido ósseo primário tanto pela ossificação intramembranosa, como também por ossificação endocondral, que ocorre através de pequenos pedaços de cartilagem que ali se formaram.

Após um tempo, esse colar conjuntivo evolui de modo a aparecer um calo ósseo rígido (calo duro) feito de tecido ósseo primário (Figura $2 \mathrm{c}$ ), que une fortemente o osso fraturado. Posteriormente, esse calo ósseo é remodelado pelo corpo e o tecido ósseo primário é substituído gradativamente pelo tecido ósseo secundário (Figura 2d) (Junqueira e Carneiro, 2013).

Figura 2: Esquema da reconstrução óssea: a) formação do hematoma; b) calo mole; c) calo duro; d) remodelação óssea

a)

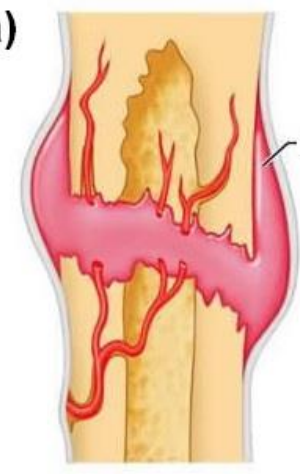

c)

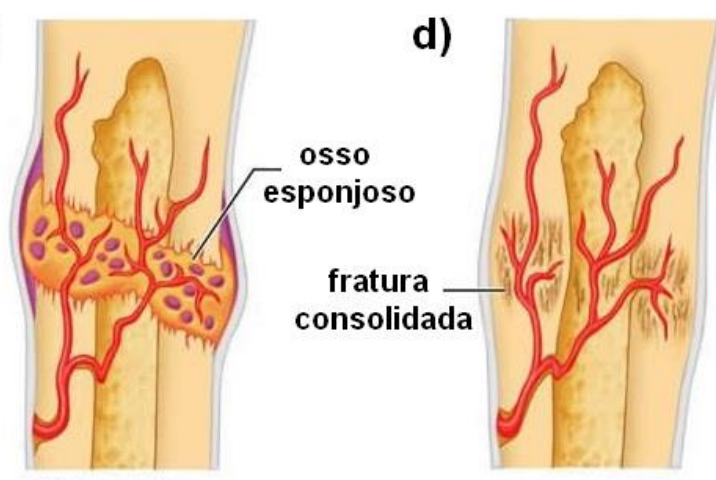

Fonte: Adaptado de Maried (2007)

b)

d)

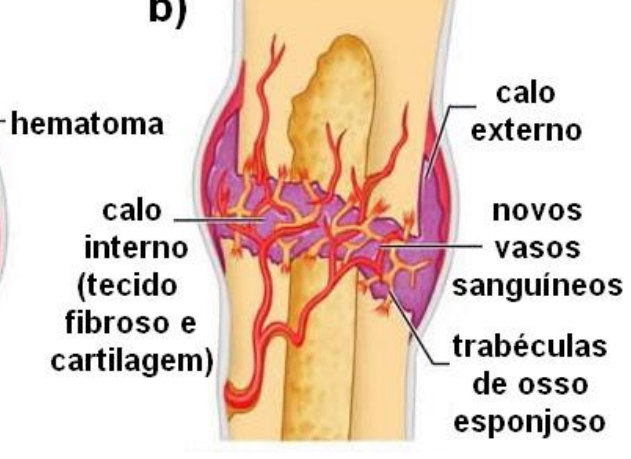
esponjoso 


\subsection{Hidroxiapatita}

As apatitas, também conhecidas como fosfatos de cálcio apatíticos, são uma família de minerais de mesma estrutura que pertencente ao grupo dos fosfatos e podem ter ocorrência natural biológica ou geológica. Em sistemas biológicos, a apatita ocorre como o principal componente inorgânico de ossos e dentes de vertebrados, alguns tipos de escamas de peixes e em algumas conchas (Brown e Constantz, 1994). As apatitas também podem ser sintetizadas em laboratórios, sendo que seu uso é destinado ao reparo, aumento ou substituição óssea ou para revestimentos e implantes dentários e ortopédicos.

A hidroxiapatita (HA) é uma biocerâmica, sendo uma das formas mais estáveis dos fosfatos de cálcio e caracterizando-se pela baixa solubilidade em sistemas aquosos. Essa biocerâmica apresenta razão Ca/P igual a 1,67 (Costa et al. 2009), entretanto, essa razão pode variar em decorrência da localização da HA no corpo, podendo ser de 1,62 a 1,64 para o esmalte do dente humano ou para a dentina (Brown e Constantz 1994), ou variar de 1,37 a 1,87 devido a substituição íons na fase mineral óssea, já que sua estrutura permite a troca catiônica do $\mathrm{Ca}^{2+}$ por íons como $\mathrm{Pb}^{2+}, \mathrm{Cd}^{2+}, \mathrm{Cu}^{2+}, \mathrm{Zn}^{2+}, \mathrm{Sr}^{2+}, \mathrm{Co}^{2+}$ ou $\mathrm{Fe}^{2+}$ (Mucalo, 2015). A razão também pode aumentar com o envelhecimento do osso, em consequência da maior deposição de cálcio nos ossos (Brown e Constantz 1994).

A formula química da hidroxiapatita é $\mathrm{Ca}_{5}\left(\mathrm{PO}_{4}\right)_{3}(\mathrm{OH})$, entretanto é normalmente representada como $\mathrm{Ca}_{10}\left(\mathrm{PO}_{4}\right)_{6}(\mathrm{OH})_{2}$ para indicar duas fórmulas mínimas dentro da célula primitiva. Sua estrutura cristalina é hexagonal, tendo a simetria $P 6_{3} / m$ de grupo espacial (Hench, 2013). A estrutura da hidroxiapatita é representada na Figura 3.

Essa biocerâmica tem sua aplicação como biomaterial na área da enxertia óssea, utilizada na reconstrução e preenchimento de tecido duro (Stevens, 2008). A hidroxiapatita se destaca em relação a outras biocerâmica por sua biocompatibilidade, já que é o componente majoritário da parte inorgânica do osso, e por sua biodegradabilidade, já que é sujeita a ação de osteoclastos, podendo ser absorvida pelo organismo (Alt et al., 2016). 
Figura 3: Representação da a) estrutura cristalina; b) estrutura hexagonal;

c) célula primitiva da hidroxiapatita

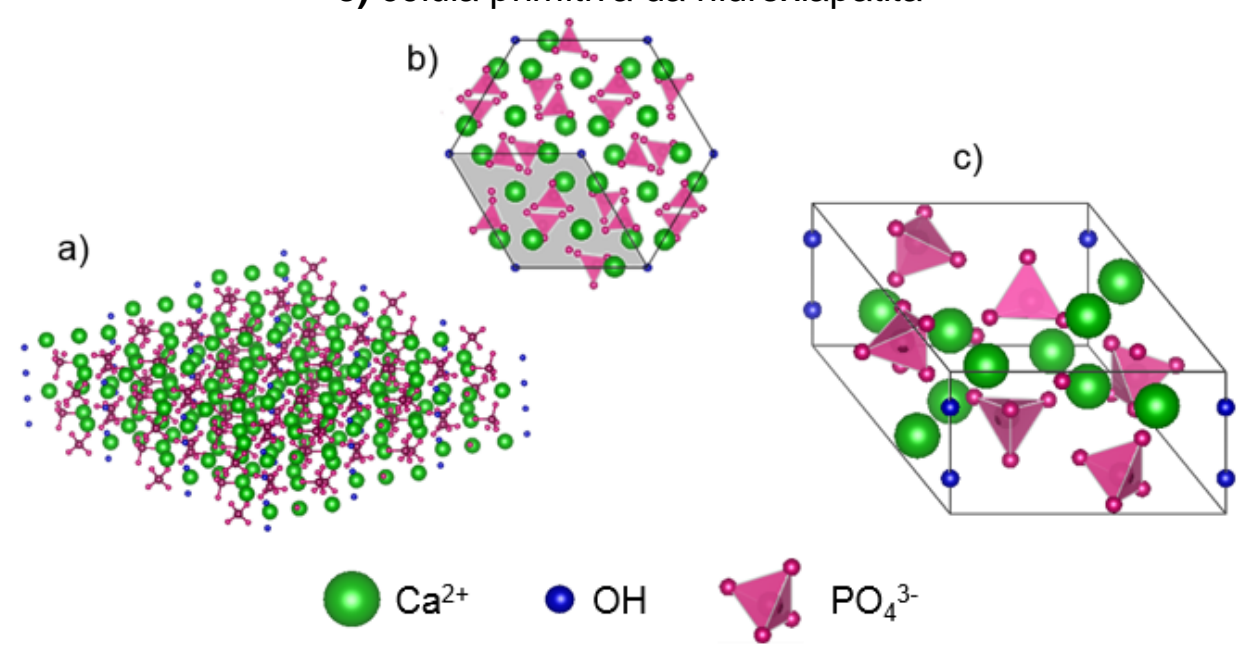

Fonte: Autoria própria

Além disso, a HA apresenta bioatividade e propriedades osteoindutoras e osteocondutoras. Sua bioatividade se dá pela capacidade de formar ligações químicas com os ossos ou cartilagens, aumentando assim a velocidade de formação de um novo tecido ósseo ao redor de implantes, diminuindo o tempo de cicatrização e de tratamento. Matrizes de HA também podem auxiliar na mineralização da matriz orgânica durante a regeneração do tecido ósseo e servir de matriz para a adesão, proliferação e diferenciação celular (Hench, 2013; Alt et al., 2016; Bezerra et al., 2017; Yang et al., 2018; Pearson et al., 2019).

Uma das vantagens da síntese da hidroxiapatita é a possibilidade de manipulação do tamanho de partículas (Liu et al., 2018). Quanto menor for o tamanho da partícula de hidroxiapatita, maior é a relação superfície-volume, e isso ocasiona na maior sorção de proteínas e adesão celular, contribuindo para uma reparação óssea mais rápida (Ghomi et al., 2011; Elhendawi et al., 2014; Thomson et al., 1998).

Apesar dessas propriedades, a HA apresenta diversas limitações quando utilizada de maneira isolada, como a alta fragilidade e difícil aplicação no osso lesado. Para reduzir essas limitações, a hidroxiapatita é normalmente combinada com outros biopolímeros, tais quais o colágeno, a quitosana, a celulose ou a gelatina, obtendo-se matrizes com propriedades mecânicas mais adequadas à reconstrução tecidual. Além disso, podem-se adicionar fármacos ou diferentes tipos de células ao compósito, a fim de se melhorar as propriedades biológicas e de regeneração tecidual.

Visando um material adequado para reparação óssea, Quinlan et al. (2015) desenvolveram scaffolds de colágeno e hidroxiapatita incorporados com PLGA 
(poli(ácido lático-co-ácido glicólico)) e alginato para liberação localizada de rhBMP-2, um fator pró-osteogênico. Como resultado, tiveram êxito ao observar uma regeneração óssea significativa comparando ao grupo controle.

Outro exemplo de aplicação de scaffolds de colágeno com hidroxiapatita foi desenvolvido por Liu et al. (2016), que adicionaram as células-tronco da medula óssea para obter um material para regeneração periodontal. Com isso, obtiveram materiais que podem ser utilizados na regeneração periodontal, entretanto a contribuição das células tronco não foi significante.

He et al. (2018) desenvolveram materiais a base de colágeno, HA e celulose microfibrilada para regeneração óssea e destacaram que os materiais obtidos apresentavam propriedades físico-químicas adequadas para serem utilizados para tal.

\subsection{Colágeno}

O colágeno é a proteína fibrosa presente em maior quantidade no corpo humano, correspondendo cerca de $30 \%$ de todas as proteínas. Atualmente, existem 29 tipos de colágeno conhecidos, sendo que esses tipos podem ser diferenciados por suas estruturas primárias, definida pela ordem dos resíduos de aminoácidos que a formam (Yu et al, 2015). Esta proteína é responsável pelas principais características físicas dos tecidos que formam pele, tendões, vasos sanguíneos, intestino grosso e delgado, ossos, cartilagens e dentes, além de ser a principal proteína presente no tecido conjuntivo.

O colágeno de tipo I é fibrilar e é o mais estudado dentre todos os outros. Ele é o tipo mais encontrado no tecido conjuntivo e está presente na pele, tendões, ossos, intestinos. O colágeno de tipo II também apresenta estrutura tipo fibrilar e é o principal componente da cartilagem articular e dos discos intervertebrais. É covalentemente reticulado ao colágeno tipo $\mathrm{IX}$ e interage com pequenos proteoglicanos ricos em leucina, que influenciam a arquitetura e a função fibrilar do colágeno (Kannu et al., 2012; Karsdal, 2016).

Diferente da maioria dos tipos de colágeno, o tipo III é um homotrímero contendo três cadeias $\alpha 1$ (III) em uma tripla hélice espiralada à direita. Juntamente com o tipo I, o colágeno tipo III é encontrado no tecido conjuntivo e na pele (D’hondt et al., 2018). No tecido cicatricial, colágeno tipo I e tipo III também são encontrados com diferentes níveis de glicosilação da hidroxilisina e hidroxilação da lisina, já que estes servem de scaffold natural para a fixação dos fibroblastos. (Karsdal, 2016). 
O colágeno tipo IV apresenta estrutura na forma de rede bidimensional e é encontrado principalmente na membrana basal, matriz extracelular que subjaz às células epiteliais e endoteliais, podendo ser utilizada também como biomaterial para reconstrução epidérmica (Matsuura-Hachiya et al., 2017).

Semelhante aos tipos I, II e III, os colágenos tipo V e XI também presentam estrutura fibrilar, sendo que o tipo $V$ contribui essencialmente na fibrilação dos colágenos I e III. Além disso, está presente na matriz óssea, na córnea, em tecidos fetais e na matriz intersticial de músculos, enquanto o de tipo XI é amplamente distribuído em cartilagens, tendões, ossos e traqueia (Junqueira e Carneiro, 2013; Karsdal, 2016).

\subsubsection{Colágeno tipo I}

O colágeno do tipo I é o principal tipo encontrado no osso, correspondendo de 90 a 95\% em peso da matriz orgânica (Newman, 2004). A estrutura típica do colágeno tipo I é constituída por três cadeias polipeptídicas em forma de hélice $\alpha$, sendo duas iguais denominadas $\alpha 1$, e outra diferente denominada $\alpha 2$. As a1 contem 1055 resíduos de aminoácidos enquanto a a2 apresenta 1029 resíduos, sendo esses resíduos formados em grande parte por glicina (Gly), prolina (Pro) e hidroxiprolina. (Yu et al., 2015).

Essas três cadeias polipeptídicas se enrolam uma sobre as outras no sentido horário, oposto ao das hélices anti-horárias das cadeias $\alpha$, formando assim a unidade monomérica do colágeno tipo I, denominado tropocolágeno. Essa molécula pode chegar a $300 \mathrm{~nm}$ de comprimento e espessura que varia de 1 a $5 \mathrm{~nm}$.

A agregação longitudinal entre os tropocolágenos formam as microfibrilas, que quando agregadas lateralmente com outras microfibrilas formam as fibrilas e depois a fibra de colágeno (Okuyama, 2008).

O modelo que explica a forma na qual o tropocolágeno se organiza em microfibrilas foi proposto por J. W. Smith em 1968. O modelo de Smith aponta que as moléculas de tropocolágeno apresentam uma periodicidade $\mathbf{D}$, na qual é originada pela justaposição paralela das moléculas de tropocolágeno, já que uma cadeia apresenta um deslocamento de um quarto de seu comprimento da cadeia adjacente (Smith, 1968; Liu et al., 2019; Yu et al., 2015). 
A agregação de cinco moléculas de tropocolágeno adjacentes deslocadas um quarto uma das outras cria duas zonas distintas, sendo que uma contém mais moléculas na seção transversal que outra. A zona com cinco moléculas de tropocolágeno é denominada de zona "Overlap", e a zona onde há quatro moléculas é denominada de zona "Gap". Esse modelo de Smith também é conhecido como modelo 'quarto alternado pentafibrilar', sendo que cada período D apresenta de 64 a $67 \mathrm{~nm}$ de largura e de 30 a 35 nm de diâmetro (Jastrzebska et al., 2017; Liu et al., 2019). O tropocolágeno e o modelo de Smith são representados na Figura 4.

Figura 4: Representação esquemática a) cadeias $\alpha 1$ e $\alpha 2 ;$ b) tropocolágeno representado pela hélice tripla; c) organização estrutural das moléculas de acordo com o modelo de Smith; d) união de microfibrilas formando uma fibrila

a)

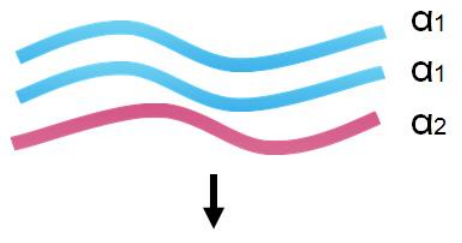

b)
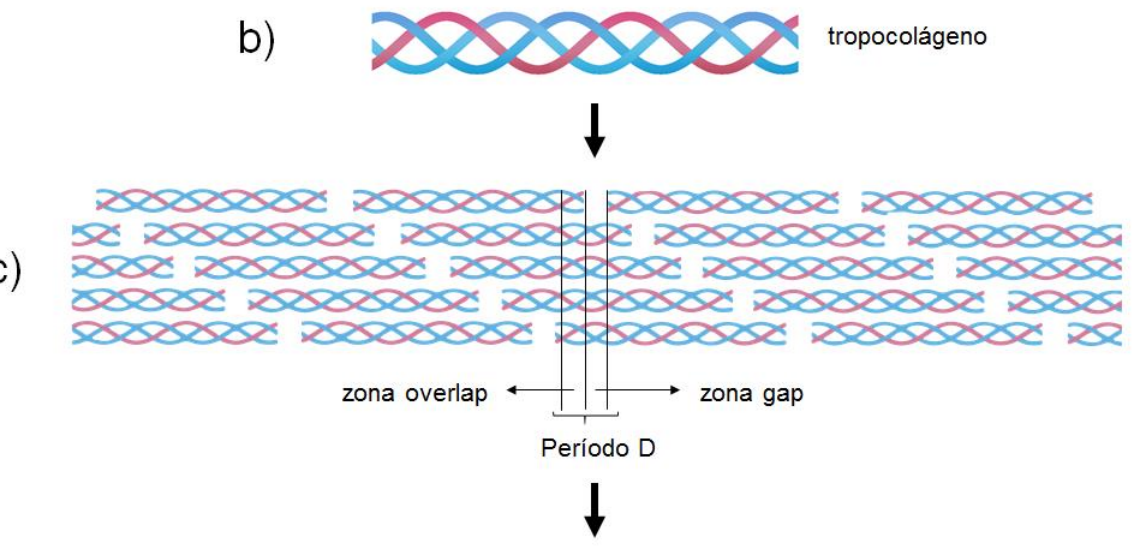

d)

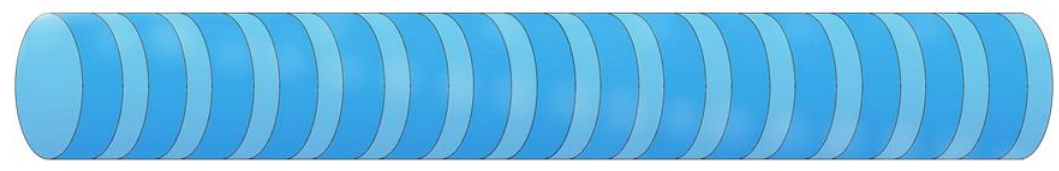

Fonte: Autoria própria

O colágeno tipo I tem utilização vasta no campo da regeneração tecidual como biomaterial. Ele apresenta biodegradabilidade, o que descarta a necessidade de uma segunda cirurgia e facilita o pós-operatório para o paciente (Pinto et al., 2017). Também apresenta propriedades hemostáticas possibilitando a redução do sangramento e manutenção do coágulo no local da ferida graças a agregação plaquetária ocasionada pela exposição de colágeno (Pontel e Boabaid, 2019). 
O colágeno também possui a capacidade de induzir e orientar a formação de novos tecidos em caso de lesão. A exposição de colágeno, que inicia o processo de hemostasia, também desencadeia cascatas químicas e fatores bioquímicos que auxiliam na reparação tecido mole como pele e músculos e tecido duro como ossos e dentes (Cen et al., 2008; Moussa et al., 2018; Liu et al., 2019).

Sua utilização como biomaterial também é decorrente da sua capacidade de ser formulado em diferentes formas, como esponjas ou matrizes, hidrogéis, filmes ou membranas. Também pode ser utilizado como sistema para liberação controlada de fármacos (Nair et al., 2010).

Esse biopolímero pode sofrer diversas modificações físicas ou químicas, como esterificação, acilação, glicosilação, desaminação dos grupos $\varepsilon$-amino da lisina, hidroxilação, proteção de guanidinas dos resíduos de arginina ou hidrólise. Essas modificações resultam em biomateriais com propriedades físico-química distintas, podendo modificar a biocompatibilidade, estabilidade ou biodegradabilidade do colágeno (Kannicht, 2019).

Outra modificação que o colágeno pode sofrer é a hidrólise seletiva dos grupos carboxiamidas dos resíduos de aminoácidos asparagina (Asn) e glutamina (Gln), como representado pela Figura 5. As fibras do colágeno tipo I se formam em pH próximo a 7,4, e após a hidrólise alcalina pode ter um aumento de até 134 cargas negativas na molécula de tropocolágeno (Bet et al., 2001).

Figura 5: Representação da hidrólise alcalina dos grupos carboxiamidas dos resíduos de Asn e Gln

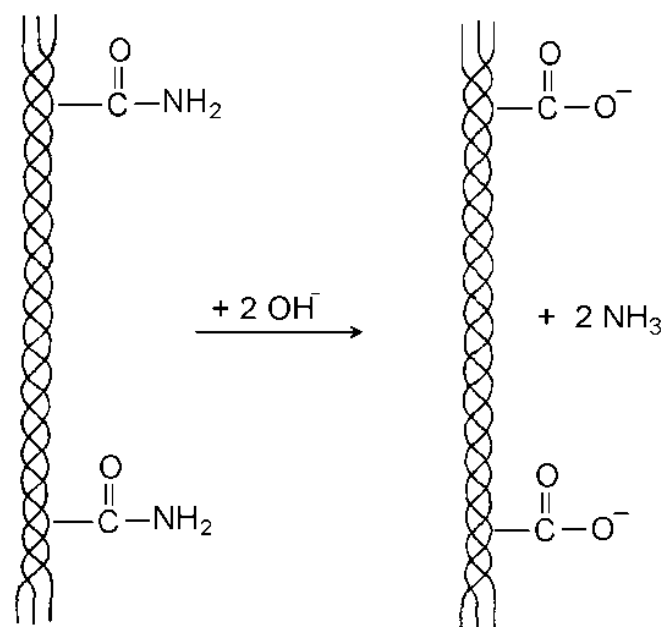

Fonte: Giglioti (2005) 
Com essa modificação, obtém-se um colágeno carregado com cargas negativas a $\mathrm{pH} 7,4$, o que aumenta sua biocompatibilidade e reduz quase que totalmente a resposta inflamatória, como mostra experimentos em subcutâneo (Goissis et al., 2000) e tíbia de rato (Rocha et al., 2002). Além disso, as cargas negativas modificam a superfície e as propriedades estruturais do colágeno, que estão intimamente relacionadas com a adsorção de proteínas, fatores de crescimento, fatores de coagulação, possibilitando um material com melhores propriedades hemostáticas e de regeneração tecidual.

A reticulação também é outra reação que pode ocorrer com o colágeno. Nesse processo também denominado de crosslink, uma ou mais cadeias poliméricas adjacentes são interligadas por moléculas que apresentam minimamente bifuncionalidade e estequiometria adequada. Essas moléculas que promovem 0 heterocruzamento entre as cadeias poliméricas são denominadas de agentes reticulantes e são capazes de modificar as propriedades do polímero, normalmente reduzindo sua solubilidade e aumentando sua viscosidade e estabilidade térmica (Canevarolo, 2002).

Atualmente, diversos flavonoides têm sido utilizados como agentes reticulantes do colágeno, formando biomateriais com melhores propriedades físicas e biológicas.

\subsection{Flavonoides}

Flavonoides são um grupo de moléculas de ocorrência no reino vegetal, encontrados principalmente em plantas superiores (gimnospermas e angiospermas) e com baixa ocorrência em musgos (Buckingham e Munasinghe, 2015). Atualmente, são conhecidos mais de 9000 compostos pertencentes ao grupo dos flavonoides (Wang et al., 2011), sendo diferenciados por seus tipos e posições de ligantes, insaturações e unidades repetitivas, mas mantendo sempre a mesma estrutura básica.

A estrutura básica dos flavonoides (Figura 6) é composta por 15 átomos de carbono no total, sendo dois anéis aromáticos com seis carbonos (anéis A e B) interconectados por um anel heterocíclico que contem três átomos (anel C). Juntos, esses anéis podem ser representados por $\mathrm{C}_{6}-\mathrm{C}_{3}-\mathrm{C}_{6}$, que é denominado de 'esqueleto' dos flavonoides ou de núcleo flavilium (Wang et al., 2018). 
Figura 6: Representação básica da estrutura dos flavonoides

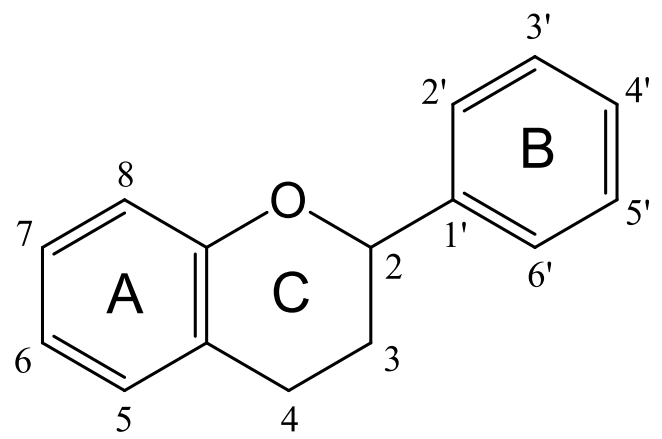

Fonte: Autoria própria

Os flavonoides são subdivididos em diversas classes, sendo que as principais são: flavonas; flavonóis; flavanonas; flavanóis, também denominadas de catequinas; isoflavonas e antocianinas. Todas essas classes são derivadas de chalconas, isômeros de di-hidroflavonas com abertura no anel C3 e precursora da biossíntese dos flavonoides (Grotewold, 2006; Khoo et al., 2017; Panche et al., 2016).

Diversos estudos já demonstram que os flavonoides apresentam características benéficas a saúde humana, apresentando propriedades antioxidantes, anti-inflamatória, antimicrobianas, antivirais, antifúngicas antialérgicas, cardioprotetoras e anti-hepatotóxicas (Davies e Yanez, 2013; Sumczynski et al., 2015; Parhiz et al., 2015; Castro-Vazquez et al., 2016; Chen et al., 2017; Camargo et al., 2017; Vicente et al., 2018; Gorniak et al., 2019).

A capacidade antioxidante dos flavonoides é em decorrência das diversas hidroxilas presentes na molécula, que por sua vez, apresentam a capacidade de transferência de átomo de hidrogênio para uma espécie reativa (radical livre) na membrana celular. Com isso, alguns flavonoides apresentam capacidade antioxidante superior à da vitamina $C$, vitamina $E$ e $\beta$-caroteno (Cho et al., 2009; Granato et al., 2018).

As hidroxilas presentes na molécula também têm ação direta sobre a atividade antifúngica (Lahtchev et al., 2008), cardioprotetora (Cheng et al., 2018) e antimicrobiana (Gorniak et al., 2019).

Um dos mecanismos de ação antimicrobiana está relacionado a modificações na parede celular das bactérias. Os flavonoides podem fazer ligações de hidrogênio entre suas hidroxilas e os grupos polares de lipídios da membrana celular bacteriana ou inibir da síntese de enzimas intracelulares e extracelulares das 
bactérias. Isso leva a modificações nas propriedades da membrana ocasionando a morte da bactéria (Gorniak et al., 2019; Reygaert, 2014).

\subsubsection{Extrato de semente de uva}

A uva é uma fruta obtida da Videira (Vitis sp.), uma trepadeira de caule denso e resistente, podendo ser encontrada principalmente em regiões de clima temperado. Sua produção no país é diferenciada pela região do plantio, sendo que na região Sul, a viticultura é direcionada para a produção de vinhos e sucos, e em outras regiões é feita para a distribuição e exportação de uvas (Mello, 2018). O cultivo de videiras no Brasil alcançou 1.416.919 toneladas em 2019 (até outubro), sendo cultivadas em um total de 74.994 hectares (IBGE, 2019).

O extrato de semente de uva é um pó marrom proveniente da produção de vinhos e espumantes, apresentando como subproduto diversos flavonoides e ácidos fenólicos. Dentre os flavonoides de maior ocorrência no extrato de semente de uva, encontram-se proantocianidinas e catequinas (Rockenbach et al., 2012; Nunes et al., 2016; Memar et al., 2019).

As proantocianidinas, também conhecidas como taninos condensados, são flavonoides que se apresentam na forma de oligômeros ou polímeros constituídos por unidades monoméricas de catequinas (flavan-3-ol). Elas são encontradas principalmente na uva, maçã, pera e cacau, e são responsáveis pela adstringência em alimentos, vinhos e espumantes (Davies e Yanez, 2013). A estrutura de um trímero de proantocianidina está representado na Figura 7.

Esses compostos apresentam grande bioatividade, tendo capacidade antioxidante 50 vezes maior que a vitamina $E$ e 20 vezes maior que a vitamina $C$, além de se destacarem também em sua ação cardioprotetora, bactericida e antiviral (Gao et al., 2019). Sua utilização no campo da engenharia tecidual vem crescendo nos últimos anos, sendo normalmente adicionados a biomateriais de reparação de tecidos duros e moles (Shavandi et al., 2018). 
Figura 7: a) fotografia da uva; b) representação da estrutura de uma proantocianidina

a)

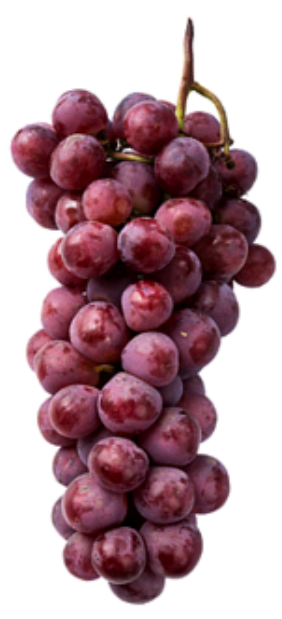

b)<smiles>Oc1cc(O)c2c(c1)O[C@H](c1ccc(O)c(O)c1)C(O)C2c1c(O)cc(O)c2c1O[C@H](c1ccc(O)c(O)c1)[C@H](O)C2c1c(O)cc(O)c2c1O[C@H](c1ccc(O)c(O)c1)[C@H](O)C2</smiles>

Fonte: Autoria própria

\subsubsection{Extrato de casca de romã}

A romãzeira (Punica granatum, L.) é uma arvore originaria do Oriente Médio cuja altura não ultrapassa 3 metros e que dá origem ao fruto denominado romã (Lorenzi e Matos, 2008). Atualmente, a romãzeira é encontrada no mundo todo e seu fruto tem coloração rósea ou alaranjada e apresenta formato arredondado.

Diversos flavonoides são identificados no extrato de romã, conferindo-a propriedades antioxidantes, bactericidas, antifúngicas, anti-inflamatórias, etc. Nele, são identificadas grandes quantidades de proantocianidinas e antocianinas, mas os flavonoides mais abundantes são as catequinas (Wafa et al., 2017; Russo et al., 2018; Lajnef et al., 2018).

As catequinas são moléculas de flavan-3-ol, ou seja, apresentam uma hidroxila ligada ao carbono 3 do anel C. Dependendo da conformação dos ligantes desse anel as catequinas podem assumir conformações diferentes.

Como exemplo, a catequina que tem conformação 2R, $3 S$ (forma trans) pode assumir conformação 2R, 3R (forma cis), sendo conhecida pelo nome de epicatequina. Ao se adicionar mais uma hidroxila ao anel B desse flavonoide, ela assume a estrutura de epigalocatequina (Buckingham e Munasinghe, 2015). A Figura 8 apresenta a estrutura de três catequinas. 
Figura 8: a) fotografia da romã; estrutura da b) catequina (2R, $3 S)$;

c) epicatequina (2R, 3R); d) epigalocatequina (2R, $3 R)$

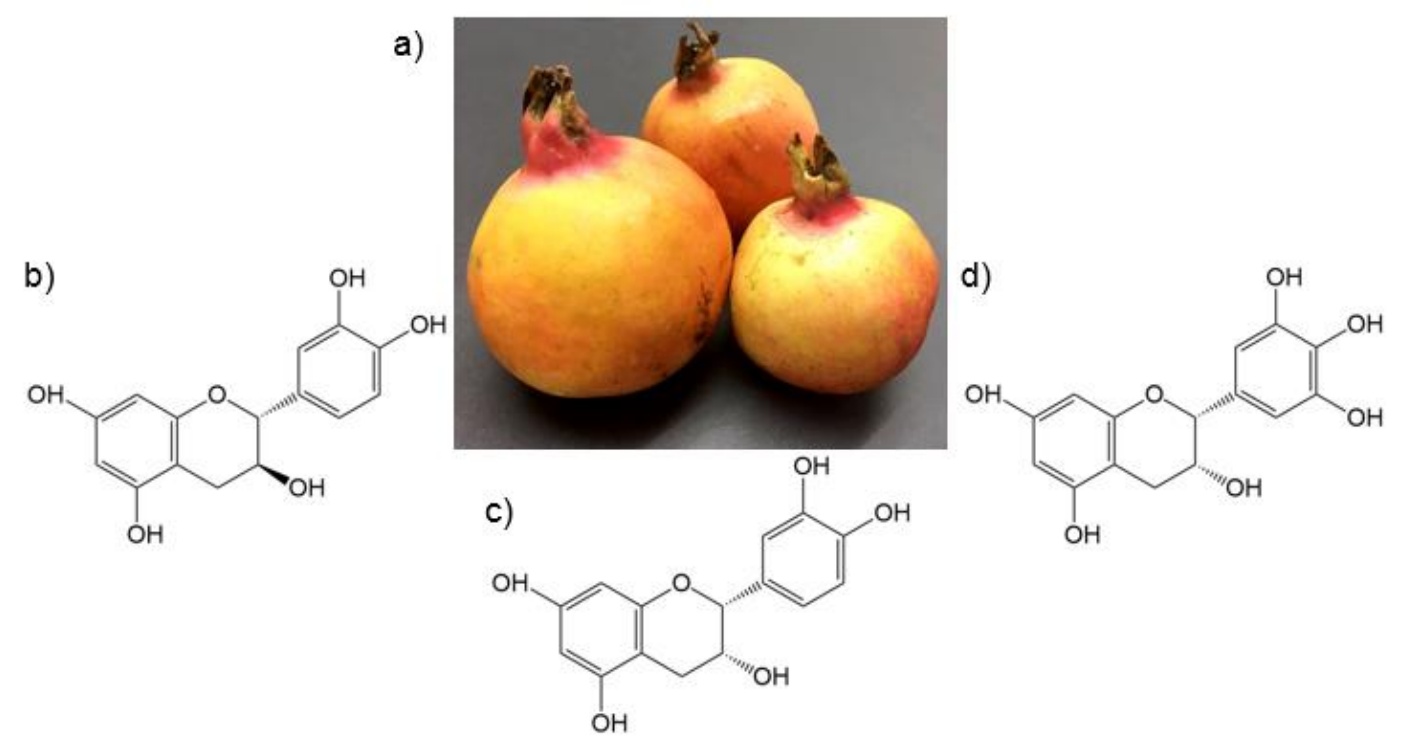

Fonte: Autoria própria

\subsubsection{Extrato de casca de jabuticaba}

A jabuticabeira (Myrciaria sp.) é uma arvore frutífera nativa das regiões sul e sudeste do Brasil, tendo grande cultivo nos estados de São Paulo, Minas Gerais, Rio de Janeiro, Goiás e Paraná. Seu fruto denominado jabuticaba (ou jaboticaba), apresenta coloração roxa ou preta, em forma esférica e apresentando de uma a quatro sementes em seu interior (Lima et al., 2008).

Assim como a uva e a romã, a jabuticaba também apresenta diversos flavonoides que a confere propriedades biológicas de interesse. No extrato da casca da jabuticaba, também são encontradas grandes concentrações de flavonoides como catequinas, flavonóis, mas os flavonoides de maior concentração são as antocianinas (Leite-Lagati et al., 2012; Rodrigues et al., 2015; Plaza et al., 2016; Marques et al., 2019).

As antocianidinas (Figura 9) são catiônicas, sendo necessariamente caracterizadas pela carga positiva no heteroátomo do anel C. In vivo, as antocianinas se encontram associadas a ânions de ácidos orgânicos e elas normalmente conferem cores avermelhadas, azuladas ou arroxeadas aos frutos (Buckingham e Munasinghe, 2015). Alguns exemplos de moléculas pertencentes a essa classe é a malvidina, peonidina, petunidina e pelargonidina. 
Figura 9: a) fotografia da jabuticaba; estrutura da b) delfinidina; c) malvidina;

d) peondina

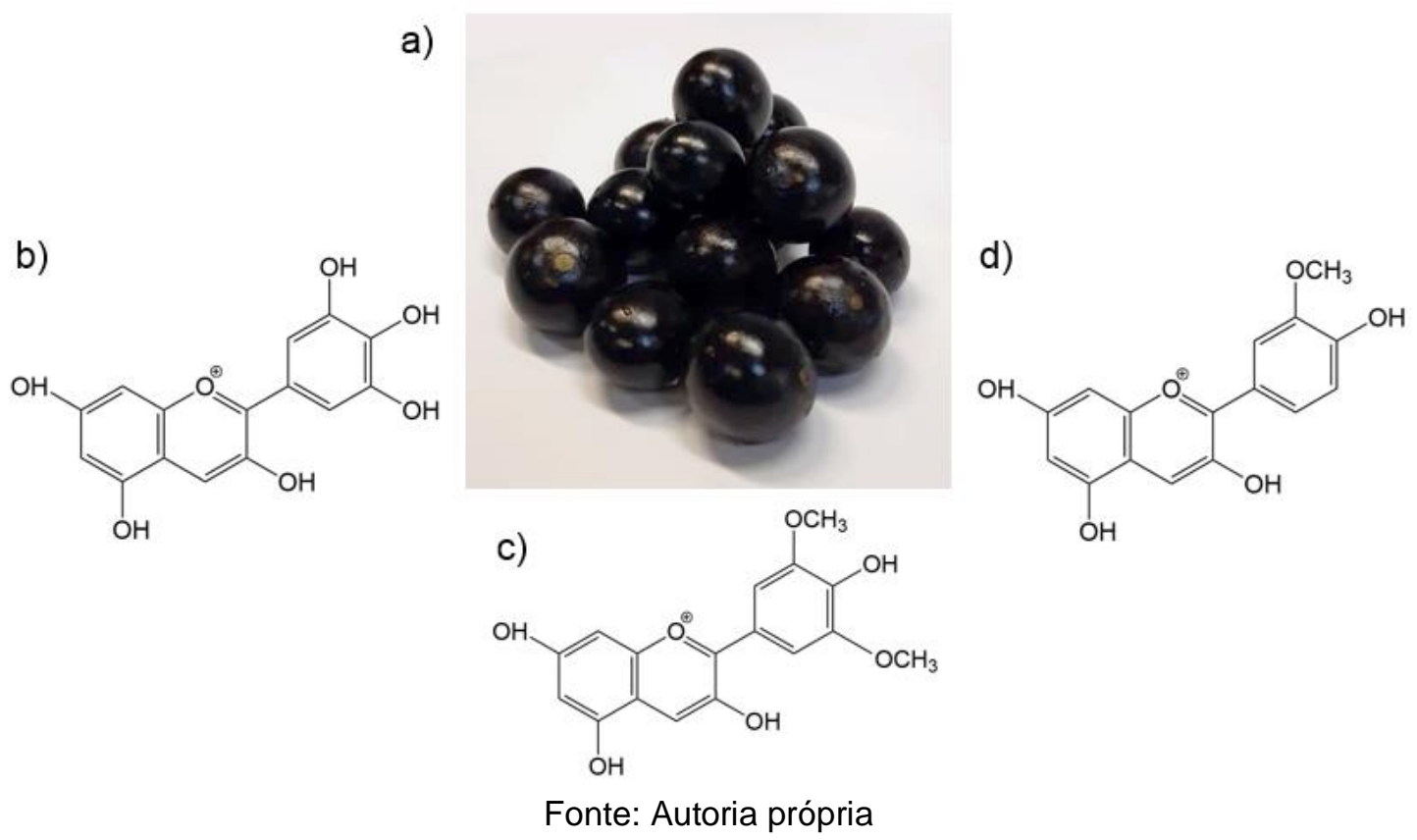

\subsection{Reticulação}

Diversos autores estudam a reação de reticulação entre os flavonoides e as cadeias polipeptídicas do colágeno, visando compreender os sítios e os tipos de ligações que ocorrem.

Carvalho (2007) discute interações entre proantocianidinas e proteínas, afirmando que as interações mais comuns são as hidrofóbicas (apolares) e ligações de hidrogênio. He et al. (2011) apontam que as ligações de hidrogênio entre os flavonoides e o colágeno ocorrem entre as hidroxilas dos flavonoides, com os grupamentos amida do aminoácido prolina presentes na constituição da hélice tripla do colágeno.

Vidal et al. (2016) apontaram que a proantocianidina atua como agente reticulante do colágeno tipo I e que há evidencias que esta interação é de tipo covalente. Epasinghe et al. (2017) também observaram que a proantocianidina, além de atuar como agente de reticulação do colágeno, ajuda na mineralização da dentina, facilitando o acumulo de minerais na matriz de colágeno.

Lucarini et al. (2019) estudaram a interação entre colágeno e catequinas e conseguiram concluir que a ligação ocorre entre os prótons do anel B do flavonoide (provavelmente das posições 2' e 5') e os prótons da hidroxiprolina e prolina do colágeno. 


\section{OBJETIVOS}

Esse projeto tem como objetivo a preparação e caracterização de matrizes feitas com colágeno aniônico proveniente de serosa porcina, nanohidroxiapatita e extratos de semente de uva, da casca de jabuticaba e da casca de romã, visando a obtenção de um material poroso com potencialidade de uso como agente de reconstrução de tecido ósseo.

Além disso, espera-se:

- Avaliar a capacidade reticulante dos flavonoides existentes nos referidos extratos quando colocados juntamente com o biopolímero.

- Estudar a influência de cada extrato e da nanohidroxiapatita na morfologia das matrizes

- Avaliar a eficácia dos extratos individualmente e nas matrizes em relação à ação antimicrobiana e citotóxica. 


\section{MATERIAIS E MÉTODOS}

\subsection{Obtenção do colágeno}

A serosa suína comprada em casa de carnes foi cortada e lavada com banhos em soluções de ácido acético $0,5 \%(\mathrm{v} / \mathrm{v})$ e hidróxido de sódio 0,5\% (massa/volume) para remoção de sangue e gordura. Posteriormente passou por hidrólise alcalina (Horn et al., 2009) em solução com hidróxidos, cloretos e sulfatos de $\mathrm{K}^{+}, \mathrm{Ca}^{2+}$ e $\mathrm{Na}^{+}$por $120 \mathrm{~h}$. Essa solução de hidróxidos e sais foi removida e a serosa passou por uma solução aquosa com os mesmos sais. Após esse tratamento todos os sais foram removidos por lavagens em soluções de ácido bórico 3\% (massa/volume), água desionizada, EDTA 0,3\% (massa/volume) e novamente água desionizada, até $\mathrm{pH}$ 6,0 aproximadamente. $\mathrm{O}$ material obtido foi liofilizado até peso constante e triturado até a obtenção de flocos de colágeno

O colágeno em flocos foi solubilizado em ácido acético pH 3,5 para obtenção de uma suspensão de colágeno $3 \%$ (massa/massa). Depois, essa suspensão foi homogeneizada em um liquidificador e passada por peneira de 14 mesh, para a obtenção de um gel de colágeno 3\% (massa/massa) em massa e $\mathrm{pH} 3.5$.

\subsection{Obtenção da nanohidroxiapatita}

Para a obtenção da nanohidroxiapatita $(\mathrm{nHA})$, foi adicionada lentamente $100 \mathrm{~mL}$ de uma solução de $0,01 \mathrm{~mol} \mathrm{~L}^{-1}$ de brometo de cetrimônio (CTAB) em $0,6 \mathrm{~mol} \mathrm{~L}^{-1}$ de $\mathrm{K}_{2} \mathrm{HPO}_{4}$. Após a adição, o pH foi ajustado para $12 \mathrm{com} \mathrm{NaOH}$ e a mistura ficou sob agitação por $2 \mathrm{~h}$. Uma solução $1,0 \mathrm{~mol} \mathrm{~L}^{-1}$ de $\mathrm{CaCl}_{2}$ foi preparada e adicionada à solução anterior, sob agitação constante. A suspensão formada foi colocada sob refluxo a $100^{\circ} \mathrm{C}$ por $6 \mathrm{~h}$, e posteriormente em ultrassom por $1 \mathrm{~h}$. Depois, a suspensão foi centrifugada e lavada duas vezes com água deionizada e uma vez com etanol, sendo então centrifugada. Após essa etapa, o precipitado foi colocado a $40^{\circ} \mathrm{C}$ durante $12 \mathrm{~h}$ para a evaporação do solvente. Por último, o precipitado seco foi calcinado a $550^{\circ} \mathrm{C}$ durante $5 \mathrm{~h}$ (Sarfraz et al., 2011) para obtenção de um pó branco homogêneo. 


\subsection{Obtenção dos extratos}

\subsubsection{Extrato de semente de uva}

O extrato de semente de uva (Vitis sp.) foi obtido de farmácia de manipulação (req. 643528-1).

\subsubsection{Extrato de casca de romã}

Para o extrato da casca de romã (Punica granatum), cascas do fruto foram lavadas, liofilizadas e trituradas até a obtenção de um pó amarelo. Esse pó foi colocado em uma solução hidroetanólica $60 \%(\mathrm{v} / \mathrm{v})$, com agitação por $1 \mathrm{~h}$, a $50{ }^{\circ} \mathrm{C}$ (Yuan et al., 2016). Em seguida, a suspensão foi filtrada à vácuo e o filtrado foi colocado em fluxo de ar até a evaporação total do solvente. O material obtido após a evaporação parcial foi liofilizado para a obtenção do extrato seco.

\subsubsection{Extrato de casca de jabuticaba}

Para o extrato da casca de jabuticaba (Myrciaria sp.), cascas do fruto foram lavadas, liofilizadas e trituradas até a obtenção de um pó roxo. A extração foi feita com uma solução hidroetanólica $95 \%(\mathrm{v} / \mathrm{v})$ acidificada com HCl 1,5 $\mathrm{mol} \mathrm{L}^{-1}$, sob agitação por $12 \mathrm{~h}$ (Lima, 2009). Posteriormente, a solução passou pelo mesmo procedimento do extrato de casca de romã, ou seja, filtragem, evaporação e liofilização até a obtenção do extrato de casca de jabuticaba seco.

\subsubsection{Soluções dos extratos}

Solução dos extratos de semente de uva $(P)$, casca de romã $(R)$ e casca de jabuticaba $(\mathrm{J})$ foram feitas por adição dos respectivos extratos em 2,0 $\mathrm{mL}$ de uma solução de ácido acético $(\mathrm{pH} 3,5)$ etanol $(1: 1, \mathrm{v} / \mathrm{v})$.

\subsection{Obtenção das matrizes}

As matrizes foram preparadas seguindo as seguintes proporções:

- A cada $10 \mathrm{~g}$ de gel de colágeno 1,5\% (massa/massa), foram adicionados $30 \mathrm{mg}$ de nanohidroxiapatita. 
- A cada $10 \mathrm{~g}$ de gel de colágeno $1,5 \%$, foram adicionados $25 \mathrm{mg}$ de extrato solubilizado na solução de ácido acético:etanol (1:1, v/v).

- A cada 10,03 g de gel de colágeno 1,5\% com $\mathrm{nHA}$, foram adicionados $25 \mathrm{mg}$ de extrato solubilizado na solução de ácido acético:etanol $(1: 1, v / v)$.

Para obtenção da matriz apenas de colágeno, o gel de colágeno 3\% (massa/massa) foi diluído em ácido acético pH 3,5 até a concentração 1,5\% (massa/massa).

Para as matrizes de colágeno com nHA, no volume de ácido acético necessário para se diluir o colágeno até $1,5 \%$, foi suspensa a nanohidroxiapatita para depois ser adicionada lentamente ao gel, sob agitação constante, em agitador mecânico a aproximadamente 900 rpm.

Para as matrizes de colágeno (com ou sem $\mathrm{nHA}$ ) e extrato, os extratos em solução de ácido acético $(\mathrm{pH} 3,5)$ etanol $(1: 1, \mathrm{v} / \mathrm{v})$ foram adicionados ao gel de colágeno $1,5 \%$ lentamente, com agitação constante em agitador mecânico a aproximadamente $900 \mathrm{rpm}$.

Com isso, foram obtidos 8 géis distintos, que foram colocados em moldes de teflon $\AA$ com $1,0 \mathrm{~cm}$ de diâmetro (aproximadamente $0,85 \mathrm{~g}$ de gel em cada poço) e liofilizados até peso constante, para obtenção das matrizes apresentadas na Tabela 1.

Tabela 1: Denominação das matrizes e suas respectivas composições

\begin{tabular}{cc}
\hline Matriz & Composição \\
\hline $\mathrm{C}$ & colágeno \\
$\mathrm{CP}$ & colágeno + extrato de semente de uva \\
$\mathrm{CR}$ & colágeno + extrato de casca de romã \\
$\mathrm{CJ}$ & colágeno + extrato de casca de jabuticaba \\
$\mathrm{CnHA}$ & colágeno $+\mathrm{nHA}$ \\
$\mathrm{CnHAP}$ & colágeno $+\mathrm{nHA}+$ extrato de semente de uva \\
CnHAR & colágeno $+\mathrm{nHA}+$ extrato de casca de romã \\
CnHAJ & colágeno $+\mathrm{nHA}+$ extrato de casca de jabuticaba \\
\hline
\end{tabular}

As matrizes foram neutralizadas em vapor de amônia por um período de $2 \mathrm{~h}$ e depois aeradas sob fluxo de ar constante por $72 \mathrm{~h}$. 


\subsection{Caracterização}

A serosa tratada foi caracterizada por calorimetria exploratória diferencial (DSC) quanto a sua temperatura de desnaturação (Td) e por espectroscopia na região do infravermelho (FTIR) quando sua característica estrutural.

Os extratos de semente de uva, casca de romã e casca de jabuticaba foram caracterizados por FTIR, citotoxicidade, ação antimicrobiana (concentração inibitória mínima, CIM e concentração bactericida mínima, CBM) e concentração de flavonoides totais, através de espectroscopia na região ultravioleta-visível (Uv-vis).

A nanohidroxiapatita foi analisada por FTIR, por espectroscopia por energia dispersiva de raios $X(E D X)$ para a obtenção da relação $\mathrm{Ca} / \mathrm{P}$, por microscopia eletrônica de varredura (MEV) para observação da morfologia e tamanho das partículas, por difração de raios-X (DRX) e ainda por ensaios de citotoxicidade.

As oito matrizes foram caracterizadas por DSC e MEV, por ensaios de porosidade em imersão de etanol, cinética de absorção de tampão fosfato salino (PBS) e degradação via colagenase. Também foram caracterizados frente à atividade antimicrobiana por ensaio de disco difusão e por citotoxicidade.

\subsubsection{Espectroscopia na região do infravermelho (FTIR)}

As análises de espectroscopia na região do infravermelho foram feitas na Central de Análises Químicas (CAQI), do Instituto de Química de São Carlos (IQSC) com auxílio do Sr. Aldimar T. J. Constante.

Os extratos de semente de uva, casca de romã, casca de jabuticaba, o fosfato de cálcio obtido e o colágeno foram colocados em dessecador contendo $\mathrm{NaOH}(\mathrm{s})$ por um período de $24 \mathrm{~h}$ para remoção da umidade residual. Os extratos e o fosfato de cálcio foram analisados em pastilhas de $\mathrm{KBr}$ e o colágeno foi prensado e analisado por ATR (refletância total atenuada). Utilizou-se um espectrofotômetro de FT-IR Shimadzu IR Affinity - 1, na faixa de $4000-400 \mathrm{~cm}^{-1}$, resolução de $4 \mathrm{~cm}^{-1} \mathrm{e}$ 16 scans. 


\subsubsection{Análise da concentração total de flavonoides}

Para a determinação da concentração de flavonoides totais os extratos de casca de romã e jabuticaba foram preparados em solução hidroetanólica $70 \%$ na concentração de $0,5 \mathrm{mg} / \mathrm{mL}$. Em uma alíquota de $0,5 \mathrm{~mL}$ dessa diluição foram adicionados 4,3 $\mathrm{mL}$ de solução hidroetanólica $70 \%, 0,1 \mathrm{~mL}$ de nitrato de alumínio 10\% e $0,1 \mathrm{~mL}$ de acetato de potássio. A solução repousou por $40 \mathrm{~min}$ e as leituras foram feitas em um espectrofotômetro de UV-Visível da HITACHI, modelo U-1100, no comprimento de onda de $425 \mathrm{~nm}$. A curva analítica foi feita nas concentrações de $45,40,30,25,15,10,5 \mu \mathrm{g} \mathrm{mL}^{-1}$ de quercetina (flavonoide da classe dos flavonóis) e os resultados foram expressos em mg quercetina/g de extrato ( $\mathrm{mg} \mathrm{QE} \mathrm{g}^{-1}$ ) (Neves et al., 2009).

\subsubsection{Espectroscopia por energia dispersiva de raios X (EDX)}

A análise por EDX foi feita na CAQI, do Instituto de Química de São Carlos (IQSC), com auxílio do Dr. Marcio de Paula.

A análise foi feita em um equipamento EDX LINK ANALYTICAL, (Isis System Series 200), com detector de SiLi Pentafet, janela ultrafina ATW II (Atmosphere Thin Window), acoplado a um Microscópio Eletrônico LEO 440 (LEO Electron Microscopy Ltd), com um detector Oxford (Oxford Instruments Inc.). Para essa análise, o fosfato de cálcio foi aderido ao stub através de fita condutora de carbono seguido de recobrimento com carbono. Para a análise semi-quantitativa foi utilizado o ISIS software 3.1. A razão cálcio/fosforo em triplicata foi obtida por divisão das porcentagens atômicas desses elementos.

\subsubsection{Difração de raios-X (DRX)}

As análises por DRX foi feita no Laboratório Multiusuário de Cristalografia Estrutural (LAMUCRES) do Grupo de Cristalografia do Instituto de Física de São Carlos (IFSC-USP), com auxílio do Sr. José Augusto Lopes da Rocha.

Os difratogramas da HA foram obtidos em um difratômetro Rigaku Rotaflex, modelo: $\mathrm{RU200B}$, com radiação monocromática de CuKa (I=1,5418 Å) com potência de $40 \mathrm{kV}, 60 \mathrm{~mA}$, operado em modo de varredura. A amostra teve a varredura de $2 \theta$ entre $5-70^{\circ}$ utilizando-se um passo de $0,02^{\circ}$ e tempo de $1^{\circ}$ por minuto. Os 
difratogramas obtidos foram comparados com padrões encontrados no JCPDS (Joint Committee for Powder Diffraction Studies - HA, JCPDS 9-0432) e o tamanho dos cristais calculados pela equação de Scherrer (Equação 1 ), sendo $\mathrm{K}$ igual a 0,94, 0 comprimento de onda $(\lambda)$ do Raio-X igual a 0,154056 nm (CuKa) e $\beta$ a largura na metade da altura do pico de difração 002.

$$
L_{002}=\frac{\mathrm{K} \cdot \lambda}{\beta \cos \theta}
$$

O porcentual de cristalinidade foi calculado através da Equação 2, no qual $X_{c}$ é a porcentagem de cristalinidade da amostra, $V_{112 / 300}$ é a intensidade do vale entre os picos de difração referentes aos planos (112) e (300) e l 300 é a intensidade do pico de difração referente ao plano (300) (Azevedo et al., 2014).

$$
X c=\left(1-\left(\frac{V_{\frac{112}{300}}}{I_{300}}\right)\right) \cdot 100
$$

\subsubsection{Calorimetria exploratória diferencial (DSC)}

As análises foram feitas em equipamento DSC Mod 2010 (TA Instruments). Foram utilizados aproximadamente $20 \mathrm{mg}$ de amostra em um suporte de alumínio hermético, sob fluxo de nitrogênio de $80 \mathrm{~mL} \mathrm{~min}^{-1}$, com razão de aquecimento de $10^{\circ} \mathrm{C} \mathrm{min}^{-1}$, com variação de temperatura de $5-120^{\circ} \mathrm{C}$. A temperatura foi calibrada com padrão de índio e um suporte vazio foi usado como referência. A temperatura de desnaturação do colágeno (Td) foi obtida a partir do ponto médio da inflexão da curva DSC.

\subsubsection{Microscopia eletrônica de varredura (MEV)}

As análises foram feitas na CAQI, do Instituto de Química de São Carlos (IQSC), com auxílio do Dr. Marcio de Paula.

As análises da superfície da nanohidroxiapatita e das matrizes foram feitas com as amostras coladas em stubs por fita condutora de carbono e recobertas com uma fina camada de ouro de $6 \mathrm{~nm}$ de espessura em um metalizador Coating System BAL-TEC MED 020 (BAL-TEC, Liechtenstein) com pressão na câmara de 2,00 x10-2 mbar, corrente de $60 \mathrm{~mA}$ e taxa de deposição de $0,60 \mathrm{~nm} / \mathrm{s}$, possibilitando a análise 
de suas estruturas. Utilizou-se o equipamento ZEISS LEO 440 (Cambridge, England) com detector OXFORD (model 7060) operando com feixe de elétrons de $20 \mathrm{kV}$.

Para a análise da secção transversal das matrizes, estas foram hidratadas com água deionizada, congeladas em nitrogênio líquido, fraturadas com auxílio de um bisturi e liofilizadas até peso constante. Posteriormente, foram coladas em stubs e passaram pelo mesmo procedimento descrito anteriormente.

O tamanho das partículas de nHA foi obtido através do software ImageJ, utilizando-se 50 determinações com a imagem ampliada 50.000x. Nas medições, foram utilizadas uma aproximação do diâmetro de Feret nas posições horizontal e vertical conforme mostra a Figura 10.

Figura 10: Representação do diâmetro de Feret: $d_{H}$ ) horizontal e $d_{v}$ ) vertical das particulas de $\mathrm{nHA}$

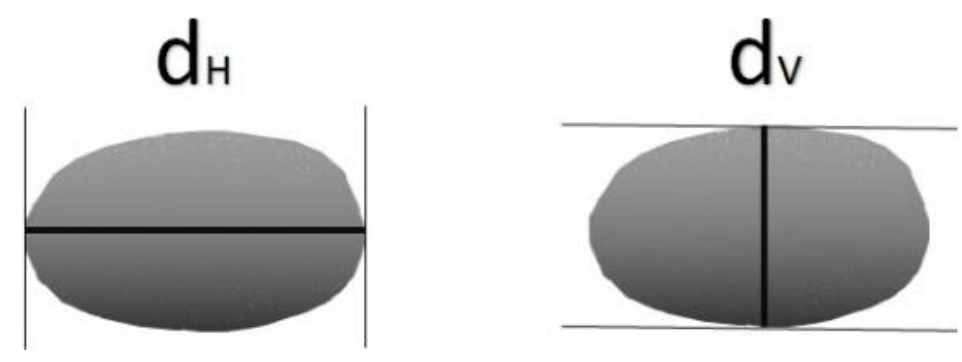

Fonte: Autoria própria

O tamanho dos poros das matrizes foi obtido através do mesmo software, com a imagem ampliada 200x e utilizando-se 40 determinações. Foi utilizada uma aproximação do diâmetro de Martin, sendo que todas as medições de poros foram feitas no mesmo sentido, conforme mostra a Figura 11. Nas medidas, foram considerados poros os interstícios que aparentavam ter maior profundidade do que largura, conforme recomenda a International Union of Pure and Applied Chemistry (IUPAC). Os tipos de poros presentes nas matrizes são representados pela Figura 12 (Rouquerol et al., 1994). 
Figura 11: Representação do diâmetro de Martin

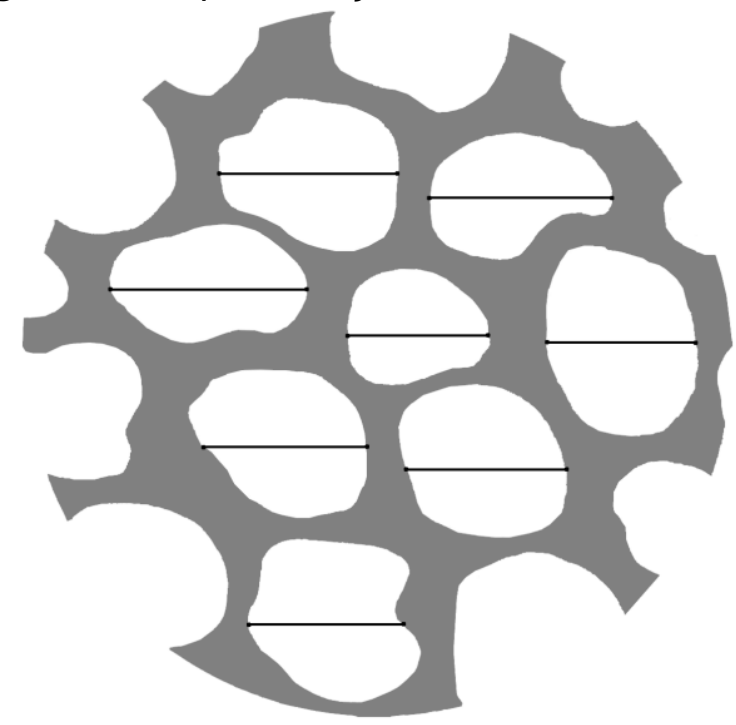

Fonte: Autoria própria

Figura 12: Representação de: a) poros abertos ou poros da superficie; b) poros fechados ou internos; c) poros interconectados; d) superficie rugosa; e) superficie compacta ou lisa

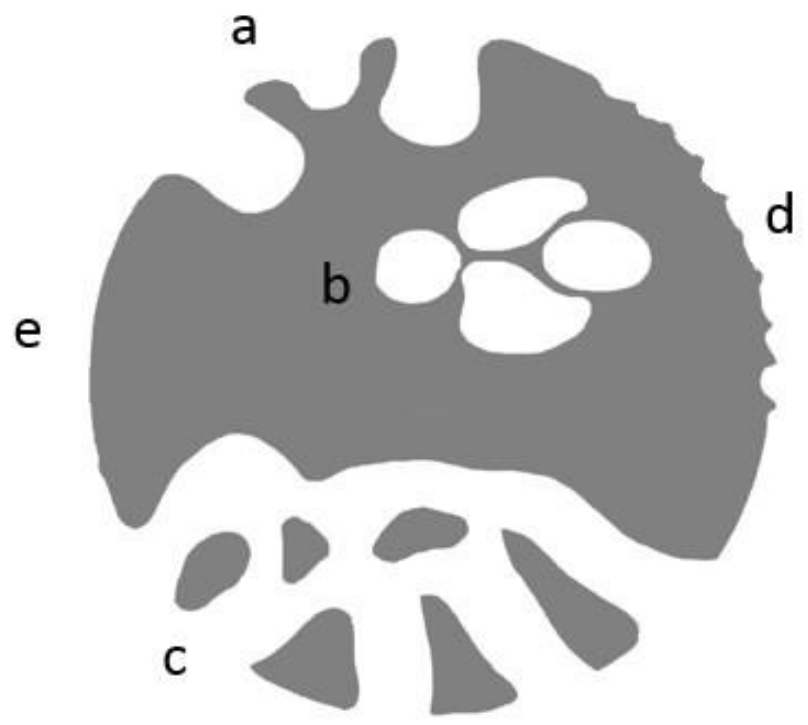

Fonte: Autoria própria

\subsubsection{Ensaio de porosidade}

Para se avaliar porosidade das matrizes, estas foram medidas com auxílio de um paquímetro visando o cálculo do volume total ( $V_{\text {total }}$ ). Posteriormente, foram colocadas em dessecador por $24 \mathrm{~h}$ na presença de $\mathrm{NaOH}(\mathrm{s})$, pesadas ( $W_{\text {inicial }}$ ) e intumescidas em $10 \mathrm{~mL}$ de etanol por 24h. Após esse período, as matrizes foram pesadas novamente ( $\left.W_{\text {final }}\right)$ e com isso, pode-se calcular o volume de etanol nas 
matrizes conhecendo-se a densidade do fluido ( $\left.\rho_{E t O H}\right)$. A partir da Equação 3, foi calculada a porcentagem de porosidade da matriz, sendo que o processo foi feito em quintuplicata.

$$
\% \text { porosidade }=\frac{\left(W_{\text {final }}-W_{\text {inicial }}\right) / \rho_{\text {EtoH }}}{V_{\text {total }}} \cdot 100
$$

\subsubsection{Cinética de absorção em PBS}

Esse procedimento foi feito colocando-se as matrizes em dessecador com $\mathrm{NaOH}(\mathrm{s})$ por $24 \mathrm{~h}$ e as pesando em seguida $\left(m_{\text {seca }}\right)$. Posteriormente foram colocadas em frascos contendo $10 \mathrm{~mL}$ de tampão fosfato salino $\mathrm{pH}$ 7,4 (PBS) e em intervalos de tempo específicos, as matrizes foram retiradas, pesadas $\left(m_{\text {umida }}\right)$ e retornadas aos frascos para novas tomadas de tempo. Para cada matriz, o processo foi feito em quintuplicata, e a porcentagem de tampão absorvido ( \% absorção) foi calculada pela média dos resultados encontrados usando a Equação 4.

$$
\% \text { absorção }=\frac{m_{\text {umida }}-m_{\text {seca }}}{m_{\text {seca }}} \cdot 100
$$

\subsubsection{Estabilidade biológica in vitro (colagenase)}

Para a determinação da estabilidade biológica in vitro, foi preparada uma solução de colagenase em tampão tris- $\mathrm{HCl} 10$ mmol L-1 a pH 7,4 contendo $25 \mathrm{mmol} \mathrm{L}^{-1}$ de $\mathrm{CaCl}_{2}$. A solução de colagenase (10 U mg-1 de colágeno) em tampão tris- $\mathrm{HCl} \mathrm{pH} \mathrm{7,4,} \mathrm{foi} \mathrm{adicionada} \mathrm{a} \mathrm{massas} \mathrm{conhecidas} \mathrm{de} \mathrm{matrizes} \mathrm{que} \mathrm{posteriormente,}$ foram colocadas em estufa bacteriológica à temperatura de $37^{\circ} \mathrm{C}$ durante períodos de 2 e 6 h. Após este período, as amostras foram lavadas com água deionizada, congeladas e liofilizadas até peso constante e a porcentagem de massa de colágeno degradada (\%degradação) foi determinada pela diferença de massa de colágeno antes ( $\left.m_{\text {inicial }}\right)$ e depois da degradação enzimática ( $\left.m_{\text {tinal }}\right)$, pela Equação 5 . Para cada matriz, o processo foi feito em quintuplicata.

$$
\% \text { degradação }=\frac{m_{\text {inicial }}-m_{\text {final }}}{m_{\text {inicial }}} \cdot 100
$$

As matrizes degradadas no período de $6 \mathrm{~h}$ foram analisadas por microscopia eletrônica de varredura, conforme apresentado no item 4.5.6. 


\subsubsection{Esterilização dos materiais}

As matrizes foram esterilizadas por radiação gama na dose de $15 \mathrm{kGy}$, no Centro de Tecnologia das Radiações (CTR) do Instituto de Pesquisa Energéticas e Nucleares (Ipen). As amostras foram irradiadas por fonte de ${ }^{60} \mathrm{Co}$ no Irradiador Multipropósito tipo compacto, com uma taxa de dose de 5 kGy/h.

\subsubsection{Ensaios de atividade antimicrobiana}

Os ensaios foram feitos no Grupo de Biotecnologia Microbiana do IQSC/USP, de responsabilidade da Profa. Dra. Márcia Nitschke e com o auxílio da doutoranda Crisiane Aparecida Marangon.

\section{(a) Obtenção das linhagens bacterianas}

As linhagens bacterianas foram obtidas de uma coleção de culturas padrão (ATCC - American Type Culture Collection) fornecidas pelo Laboratório de Referência do Instituto Oswaldo Cruz (INCQS - FIOCRUZ). As bactérias empregadas como modelo foram Staphylococcus aureus (ATCC 25923), Pseudomonas aeruginosa (ATCC 27853) e Salmonella enterica Enteritidis (ATCC 13076).

\section{(b) Padronização do inóculo}

A linhagem de $S$. aureus foi semeada em placas de ágar extrato de levedura triptona de soja (TSYEA) e as linhagens de $P$. aeruginosa e $S$. Enteritidis foram inoculadas em ágar nutriente, a partir do estoque a $-80^{\circ} \mathrm{C}$ e incubadas por $24 \mathrm{~h}$ em estufa bacteriológica a $37^{\circ} \mathrm{C}$.

\section{(c) Testes de atividade antimicrobiana dos extratos}

Para determinação da atividade antimicrobiana foram preparadas suspensões em solução salina esterilizada ( $\mathrm{NaCl}$ 0,86\%), utilizando como padrão a escala 0,5 de McFarland, que corresponde a aproximadamente $1,5 \times 10^{8}$ UFC $\mathrm{mL}^{-1}$ (Unidades Formadoras de Colônias por mL) (CLSI, 2017). Com o auxílio de uma alça esterilizada, foram selecionadas algumas colônias isoladas das culturas de $24 \mathrm{~h}$ para serem suspensas em $5 \mathrm{~mL}$ de solução salina estéril e a turbidez das suspensões foi medida em $610 \mathrm{~nm}$ em um espectrofotômetro UV-Vis (Thermo Scientific, Genesys 10 UV), de modo a obter densidade óptica entre 0,09 a 0,13. Após o ajuste das suspensões ao padrão 0,5 de McFarland, estas foram diluídas 1:10 em solução salina para obter-se uma concentração de $10^{7}$ UFC mL ${ }^{-1}$ (CLSI, 2017). 
Os ensaios para determinação da concentração inibitória mínima (CIM) dos extratos frente às linhagens de $S$. aureus, $P$. aeruginosa e $S$. Enteritidis foram feitos utilizando-se a técnica de microdiluição em caldo Müeller Hinton (MHB) de acordo com a metodologia estabelecida pelo Clinical and Laboratory Standards Institute, CLSI M7A6 2017.

Nesta metodologia, $100 \mu \mathrm{L}$ de MHB foi adicionado a todas as cavidades da microplaca. Em seguida, $100 \mu \mathrm{L}$ de cada extrato foram adicionados na coluna 1. A diluição da solução com o meio de cultura na primeira coluna resultou nas primeiras concentrações estabelecidas de $2000 \mu \mathrm{g} \mathrm{mL}-1$. Após homogeneização, $100 \mu \mathrm{L}$ da coluna 1 foram transferidos para a coluna 2, e assim sucessivamente até a coluna 10. A coluna 11 foi utilizada como controle positivo $(\mathrm{C}+)$ e a coluna 12 como controle negativo (C-). Então, $20 \mu \mathrm{L}$ do inóculo bacteriano padronizado foi adicionado nas colunas 1 a 11. Posteriormente, a microplaca foi incubada em estufa bacteriológica a $37^{\circ} \mathrm{C}$ por $24 \mathrm{~h}$.

A todas as cavidades, exceto à coluna 12, foram adicionados $20 \mu \mathrm{L}$ de inóculo da linhagem bacteriana padronizado de modo a obter uma concentração final de $10^{5}$ UFC $\mathrm{mL}^{-1}$ em cada poço da microplaca. A placa de microdiluição foi incubada a $37^{\circ} \mathrm{C}$ por $24 \mathrm{~h}$. Após o período de incubação foi feita uma avaliação visual do crescimento microbiano e nas cavidades em que não foi constatado o crescimento foram feitos os testes de CBM. Para confirmação da CIM observada na avaliação visual foram adicionados $20 \mu \mathrm{L}$ do corante brometo de 3-(4,5-dimetiltiazol-2-il)-2,5difenil-tetrazólio) (MTT) em todas as cavidades da placa. A CIM foi determinada como a menor concentração de agente antimicrobiano que inibe completamente 0 crescimento das bactérias em relação ao controle positivo.

Com auxílio de uma alça de inoculação esterilizada, foi transferida uma alíquota do meio das cavidades em que não houve crescimento visual microbiano para placas de TSYEA, que foram incubadas a $37^{\circ} \mathrm{C}$ por $24 \mathrm{~h}$. A menor concentração que não apresentou crescimento microbiano nas placas foi designada como a CBM. 
(d) Testes de atividade antimicrobiana das matrizes

As matrizes foram previamente esterilizadas por radiação gama, no Centro de Tecnologia das Radiações (CTR) do Instituto de Pesquisa Energéticas e Nucleares (Ipen) de São Paulo, conforme o item 4.5.10.

Para determinar a CIM das matrizes, foram feitos ensaios utilizando-se a técnica de disco difusão (CLSI, 2017). Foram utilizados como controle positivo de crescimento, uma placa de meio cultura com o inóculo bacteriano para confirmação do crescimento bacteriano no meio. Como controle negativo, foram utilizados discos de papel de filtro $\left(5 \mathrm{~mm}\right.$ ) contendo antibiótico $20 \mu \mathrm{L}$ (ampicilina $50 \mu \mathrm{g} \mathrm{mL}^{-1}$ ) como controle de qualidade do ensaio com antibiótico padrão e matrizes de mesmo tamanho em uma placa de meio de cultura sem o inóculo bacteriano para comprovação da esterilidade das amostras.

Com auxílio de um swab, uma alíquota do inóculo padronizado na concentração $10^{8}$ UFC mL ${ }^{-1}$ foi espalhada em placas de ágar Müeller Hinton (MHB) e aguardou-se 10 minutos. Então, os discos foram distribuídos sobre a superfície das placas com auxílio de pinça esterilizada. O ensaio foi em duas condições de incubação em estufa bacteriológica por 18-24 h: incubação imediata das placas a $37^{\circ} \mathrm{C}$ e incubação após deixar as placas por $2 \mathrm{~h}$ em geladeira.

Após o período de incubação foi feita uma avaliação visual do crescimento e a leitura da CIM deu-se pela medida do diâmetro do halo de inibição de crescimento bacteriano. O ensaio foi feito com no mínimo três repetições independentes (Michalska-Sionkowska et al., 2017).

\subsubsection{Citotoxicidade}

Os testes de citotoxicidade in vitro foram feitos no Centro de Biotecnologia (CB) no Instituto de Pesquisa Energéticas e Nucleares (Ipen), sob orientação da Profa. Dra. Monica Beatriz Mathor e auxílio da pesquisadora Maria Fátima Guarizo Klingbeil e da doutoranda Lívia Contini Massimino. Todas as manipulações foram feitas em capela de fluxo laminar, com materiais esterilizados, conforme norma ISO 10993-5.

\section{(a) Linhagem celular}

Para o ensaio celular foi utilizada a linhagem celular NIH/3T3 (ATCC CRL 1658), linhagem de fibroblastos de camundongo. A linhagem celular cresce aderida devido à sua morfologia (ATCC, 2019) em garrafas de polipropileno contendo meio de 
cultura Dulbecco's Modified Eagle's Medium (DMEM) suplementado com 10\% de soro fetal bovino, glutamina $4 \mathrm{mM}$ e solução antibiótico/antimicótico de penicilina $100 \mathrm{UI} \mathrm{mL} \mathrm{mL}^{-1}$, estreptomicina $100 \mu \mathrm{g} \mathrm{mL}^{-1}$ e anfotericina $0,025 \mu \mathrm{g} \mathrm{mL}^{-1}$. As células foram mantidas a $37^{\circ} \mathrm{C}$, em estufa com $5 \%$ de $\mathrm{CO}_{2}$ (Freshney, 2010). Os repiques foram feitos conforme as características da linhagem. Todas as manipulações celulares foram feitas em ambiente estéril, em capela de fluxo laminar, com materiais esterilizados, a fim de se evitar contaminação.

\section{(b) Preparo das placas de cultura}

Para a determinação da viabilidade e concentração celular foram utilizados o método da contagem em câmara de Neubauer e o teste da exclusão do corante (Freshney, 2010). Neste teste o corante trypan blue foi incorporado pelas células mortas devido rompimento da integridade da membrana celular. Para isso, o meio de cultura contido nas garrafas foi descartado e solução de PBS foi utilizada para retirar o resto do meio de cultura. Após lavagem das garrafas com PBS, foi adicionada uma solução Tripsina-EDTA 0,02\%, para remoção das células da garrafa armazenadora. Após 5 minutos, foi adicionado meio de cultura, o conteúdo foi transferido para um tubo cônico e centrifugado a 1500 rpm por 5 minuto. O sobrenadante foi descartado e as células foram suspensas novamente no meio de cultura. Uma alíquota de $10 \mu \mathrm{L}$ da suspensão celular foi retirada e adicionada a $10 \mu \mathrm{L}$ de solução $0,4 \%$ de trypan blue. Essa mistura foi colocada na câmara de Neubauer, sendo as células vivas e as mortas contadas com auxílio de um microscópio óptico e a porcentagem de viabilidade foi calculada conforme a Equação 6.

$$
\% \text { de viabilidade }=\frac{\text { número de células não coradas }}{\text { número total de celulas }} \times 100
$$

As células foram plaqueadas, em placa de cultura de 96 poços, na concentração de $5 \times 10^{3}$ células $\mathrm{mL}^{-1}$ em meio de cultura. Para isso, foram distribuídos $100 \mu \mathrm{L}$ da suspensão celular por cavidade da placa de cultura estéril. As placas foram incubadas por $24 \mathrm{~h}$ em estufa, a $37^{\circ} \mathrm{C}$ e $5 \%$ de $\mathrm{CO}_{2}$. 
(c) Preparo das soluções dos extratos vegetais e nanohidroxiapatita

Para o ensaio por contato direto, foram preparadas soluções a $2,5 \mathrm{mg} \mathrm{mL}^{-1}$ em etanol a partir dos extratos de semente de uva, casca de romã, casca de jabuticaba e nanohidroxiapatita. Essas soluções foram filtradas em filtro Millipore $0,45 \mu \mathrm{m}$ para esterilização e diluídas sucessivamente com meio de cultura às concentrações de 1,250, 0,625, 0,312, 0,156 $\mathrm{mg} \mathrm{mL}^{-1}$.

\section{(d) Preparo do extrato das matrizes}

As matrizes foram previamente esterilizadas por radiação gama no CTR do Ipen, conforme o item 4.5.10.

Para preparo dos extratos, as matrizes foram colocadas em tubo de ensaio com quantidade suficiente de meio de cultura (aproximadamente $1 \mathrm{mg}$ de matriz para cada $\mathrm{mL}$ de extrato) e incubados por $24 \mathrm{~h}$ em estufa, a $37^{\circ} \mathrm{C}$ e $5 \%$ de $\mathrm{CO}_{2}$, conforme ISO 10993-12 (2012). Após esse período, as matrizes foram descartadas e os extratos obtidos foram utilizados nos ensaios de citotoxicidade.

\section{(e) Ensaio de citotoxicidade}

As placas de cultura preparadas conforme o item 4.5.11.c tiveram o sobrenadante removido por aspiração e $100 \mu \mathrm{L}$ do extrato das matrizes foi adicionado em poços determinados. Para o controle negativo foi utilizado extrato de papel de filtro estéril, enquanto que o controle positivo foi feito com extrato de látex, ambos preparados nas mesmas condições citadas no item 4.5.11.d. As placas foram incubadas nas mesmas condições por períodos 24 e $48 \mathrm{~h}$.

O corante MTS (3-(4,5-dimetiltiazol-2-il)-5-(3-carboximetoxifenil)-2-(4sulfofenil)-2H-tetrazólio) foi utilizado para o teste de citotoxicidade. Este sal é metabolizado a um sal formazan por ação de enzimas desidrogenases $\mathrm{NAD}(\mathrm{P}) \mathrm{H}$ - dependentes de células viáveis. Após a incubação das células com os extratos, o sobrenadante foi retirado e foram adicionados $20 \mu \mathrm{L}$ da solução comercial de MTS em cada poço da placa, seguido de incubação por mais 4 horas em estufa a $37^{\circ} \mathrm{C}$ e atmosfera de $5 \%$ de $\mathrm{CO}_{2}$. Após a incubação, as placas tiveram a absorbância em $490 \mathrm{~nm}$ mensurada em leitor de ELISA. 
A viabilidade celular foi obtida por comparação aos poços do controle de células, descontando-se previamente de todos os poços o valor de absorbância do branco (poços sem células, mas contendo meio de cultura e solução de MTS), conforme Equação 7.

$$
\text { Índice de viabilid. }(\%)=\frac{\text { média das absorbâncias da amostra }}{\text { média das absorbâncias do controle de células }} \times 100
$$

\subsubsection{Análise estatística}

Para as medidas de tamanho de poros das matrizes, ensaios de porosidade, cinética de absorção em PBS e degradação via colagenase, os resultados foram analisados por análise de variância (ANOVA) ou teste $t$ de Student, considerando $\mathrm{p}<0,05$ como estatisticamente diferente. 


\section{RESULTADOS E DISCUSSÃO}

\subsection{Obtenção dos materiais}

\subsubsection{Obtenção da nanohidroxiapatita}

Pela síntese da nanohidroxiapatita, foi obtido um pó branco cuja reação teve rendimento de aproximadamente $20 \%$, conforme demonstrado por Sarfraz et al (2011). A Figura 13 mostra o Efeito Tyndall de espalhamento da luz pelas partículas em suspensão de hidroxiapatita $0,1 \mathrm{mg} \mathrm{mL}^{-1}$. Esse espalhamento da luz ocorre devido às partículas em suspensão terem possivelmente dimensões entre $10^{-9} \mathrm{e}$ $10^{-6} \mathrm{~m}$, tamanho próximo ao comprimento de onda da luz visível, de $10^{-7}$ a $10^{-6} \mathrm{~m}$ (Lima, 2014).

Figura 13: Fotografia do Efeito Tyndall da suspensão de hidroxiapatita

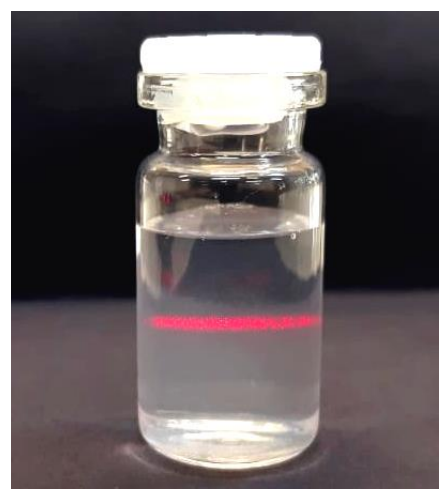

Fonte: Autoria própria

\subsubsection{Obtenção dos extratos}

Os extratos de casca de jabuticaba e de casca de romã obtidos, assim como o de semente de uva, apresentam diferentes colorações conforme mostra a Figura 14, fotossensibilidade e característica higroscópica. A fotossensibilidade é observada pelo escurecimento característico da oxidação dos extratos nas matrizes (Maini et al., 2012), enquanto a característica higroscópica é observada com o aparecimento de gotículas de água nos extratos após um período exposto ao ar. 
Figura 14: Fotografia dos extratos de: a) semente de uva; b) casca de romã;

c) casca de jabuticaba

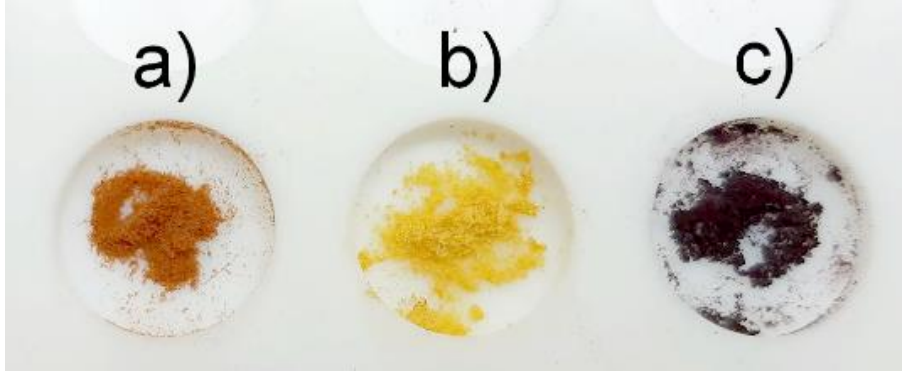

Fonte: Autoria própria

\subsubsection{Obtenção das matrizes}

As matrizes obtidas são apresentadas na Figura 15, na qual se identificam as diferentes colorações dos extratos nas matrizes. As 8 matrizes apresentam aspecto resistente ao toque e reversibilidade a pequenas deformações.

Figura 15: Fotografia digital das matrizes: a) C, b) $\mathrm{CP}$, c) $\mathrm{CR}$, d) CJ, e) $\mathrm{CnHA}$, f) $\mathrm{CnHAP}$, g) CnHAR e h) $\mathrm{CnHAJ}$

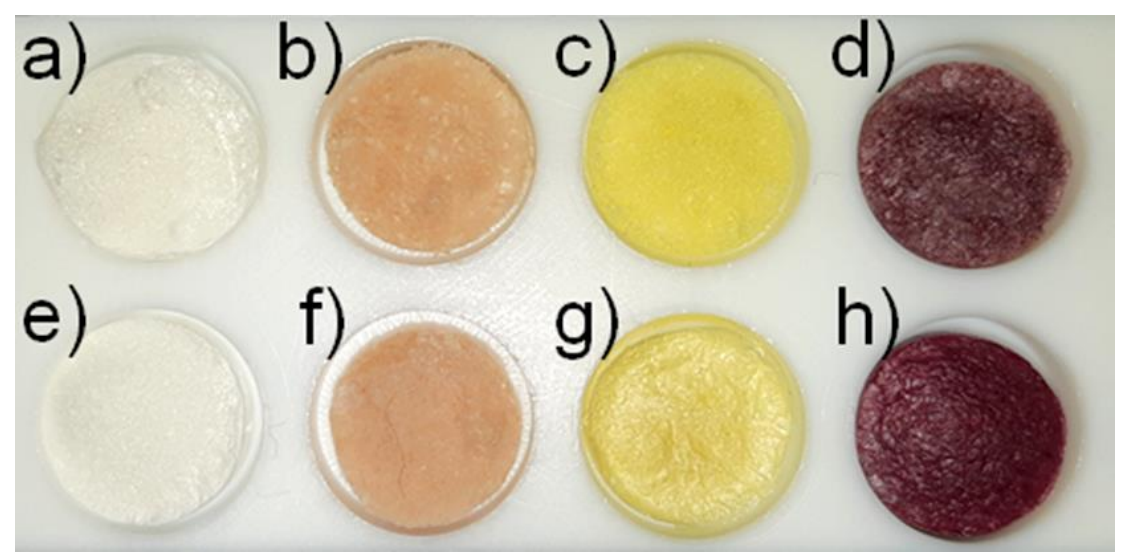

Fonte: Autoria própria

\subsection{Espectroscopia no infravermelho (FTIR)}

\subsubsection{FTIR do colágeno}

No espectro no infravermelho do colágeno apresentado na Figura 16 observa-se principalmente bandas referentes às amidas encontradas na estrutura primária da proteína. A função amida é formada quando os aminoácidos se ligam covalentemente uns aos outros através das ligações peptídicas durante a tradução. Observa-se bandas de amida $\mathrm{A}$ (estiramento $\mathrm{N}-\mathrm{H}$ de amida acoplada com ligação de 
hidrogênio) em $3325 \mathrm{~cm}^{-1}$, overtone de amida II (deformação N-H) em $3078 \mathrm{~cm}^{-1}$ e bandas de amida $B$ (estiramento $-\mathrm{CH}_{2}$ simétrica e assimétrica) em $2918 \mathrm{~cm}^{-1}$ (Riaz et al., 2018). Essa região de 3300 a $2900 \mathrm{~cm}^{-1}$ também é característica de estiramentos $\mathrm{O}-\mathrm{H}$, presentes na cadeia na cadeia polipeptídica do colágeno tipo I.

Em 1652, 1550 e $1234 \mathrm{~cm}^{-1}$ encontram-se bandas de estiramento $\mathrm{C}=\mathrm{O}$ de amida I, deformação de $\mathrm{N}-\mathrm{H}$ acoplada com estiramento $\mathrm{C}-\mathrm{N}$ de amida II e deformações $\mathrm{C}-\mathrm{N}$ acoplada à deformação $\mathrm{N}-\mathrm{H}$ de amidas III, respectivamente, presentes na cadeia principal dos resíduos de glicina e nas cadeias laterais dos resíduos de prolina (Bhuimbar et al., 2019; Sanden et al., 2019).

Deformações assimétricas de $\mathrm{CH}_{2}$ são localizadas em $1450 \mathrm{~cm}^{-1}$ e na região entre 800 e $600 \mathrm{~cm}^{-1}$ encontra-se a o estiramento da cadeia polipeptídica (estiramento do esqueleto) (Bhuimbar et al., 2019; Muyonga et al., 2004).

Figura 16: Espectro FTIR-ATR do colágeno

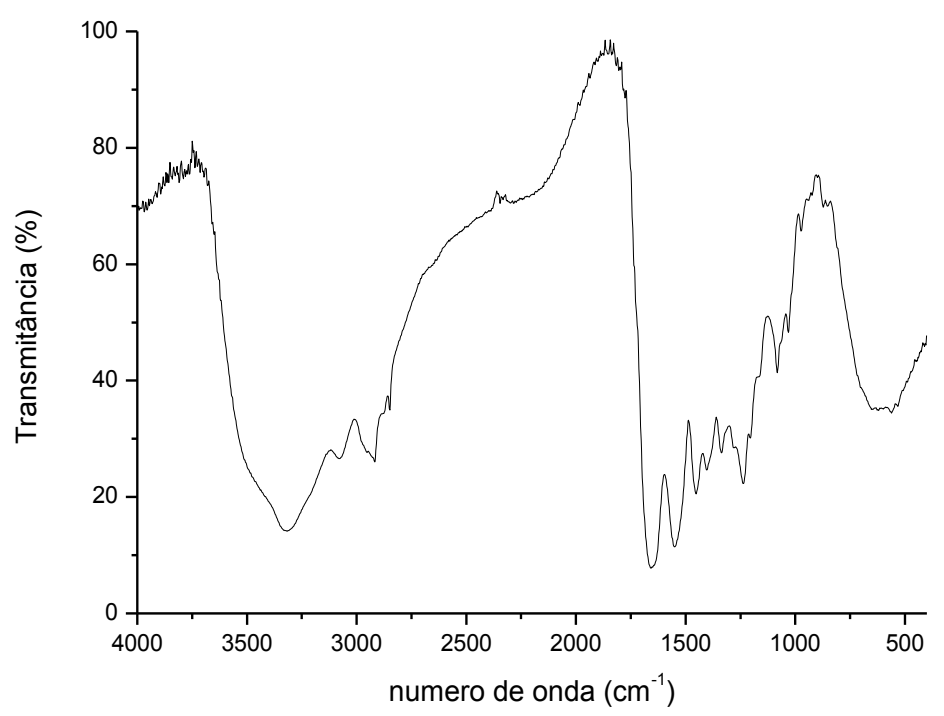

Fonte: Autoria própria

\subsubsection{FTIR da nanohidroxiapatita}

Na hidroxiapatita, a espectroscopia na região do infravermelho apresenta o estiramento do grupo O-H, próximo a $3200 \mathrm{~cm}^{-1}$ (não mostrado) e os estiramentos e deformações do íon fosfato $\left(\mathrm{PO}_{4}^{3-}\right)$. Esse íon presente na hidroxiapatita apresenta quatro modos vibracionais denominados $v_{1}, v_{2}, v_{3}$ e $v_{4}$, observados na região do infravermelho. 
O espectro FTIR da hidroxiapatita sintetizada, apresentado na Figura 17, mostra bandas acentuadas em 1083 e 1037 cm$^{-1}$, referentes ao estiramento assimétrico $\left(v_{3}\right)$, uma banda atenuada em $957 \mathrm{~cm}^{-1}$ referente ao estiramento simétrico $\left(v_{1}\right)$ do fosfato e duas bandas em 605 e $567 \mathrm{~cm}^{-1}$, referentes à deformação assimétrica em (v4). O modo vibracional v2 também referente à deformação assimétrica se apresenta próximo a $464 \mathrm{~cm}^{-1}$ (Slosarczyk et. al., 2005; Oliveira et al., 2009).

Figura 17: Espectro FTIR do fosfato de cálcio

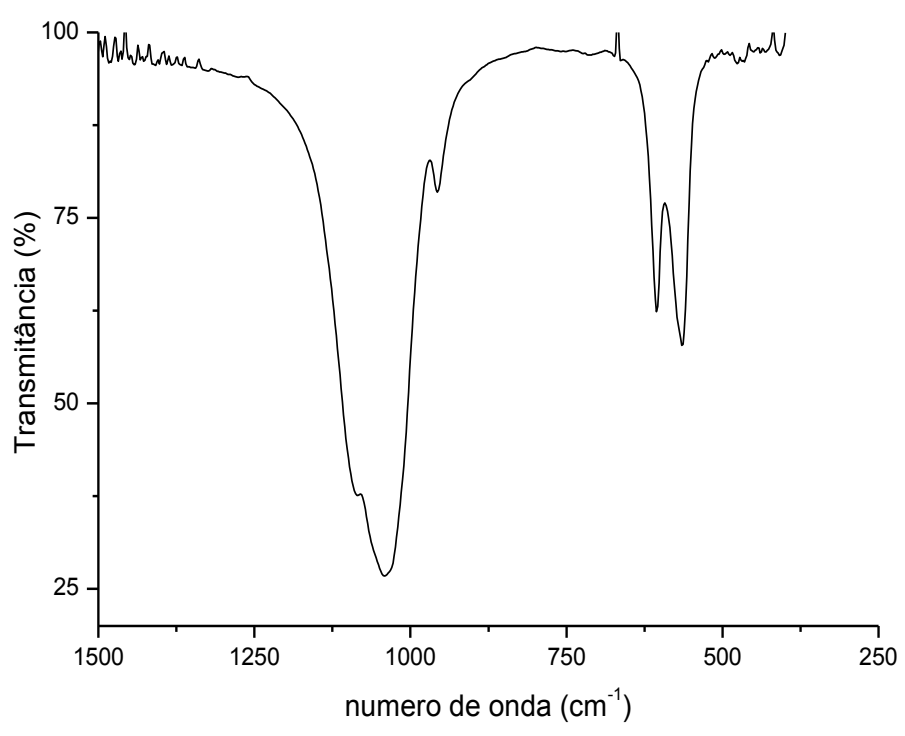

Fonte: Autoria própria

\subsubsection{FTIR dos extratos}

Para os espectros de extrato de semente de uva, casca de romã e casca de jabuticaba (Figura 18), foram observadas bandas similares, como mostrado a Tabela 2.

Nos três espectros observam-se grandes bandas semelhantes em $3400 \mathrm{~cm}^{-1}$, decorrentes não só dos estiramentos $\mathrm{O}-\mathrm{H}$ presente nas hidroxilas dos flavonoides, quanto da presença de água na amostra durante a análise, possivelmente devido ao caráter higroscópico dos extratos. As bandas em $1728 \mathrm{~cm}^{-1}(\mathrm{R})$ e $1737 \mathrm{~cm}^{-1}$ (J) podem ser atribuídas ao estiramento $\mathrm{C}=\mathrm{O}$ de grupos carboxílicos. As bandas próximas a $1615 \mathrm{~cm}^{-1}$, acompanhadas de outras de menor intensidade próximas a $1514 \mathrm{~cm}^{-1}$, são correspondentes ao estiramento do anel aromático $\mathrm{C}=\mathrm{C}-\mathrm{C}$. Próximo a $1449 \mathrm{~cm}^{-1}$, observou-se o estiramento dos grupos $\mathrm{C}=\mathrm{C}$ do anel aromático. 
Figura 18: Espectros FTIR de (-) extrato de casca de jabuticaba, (-) extrato de casca de romã e (-) extrato de semente de uva

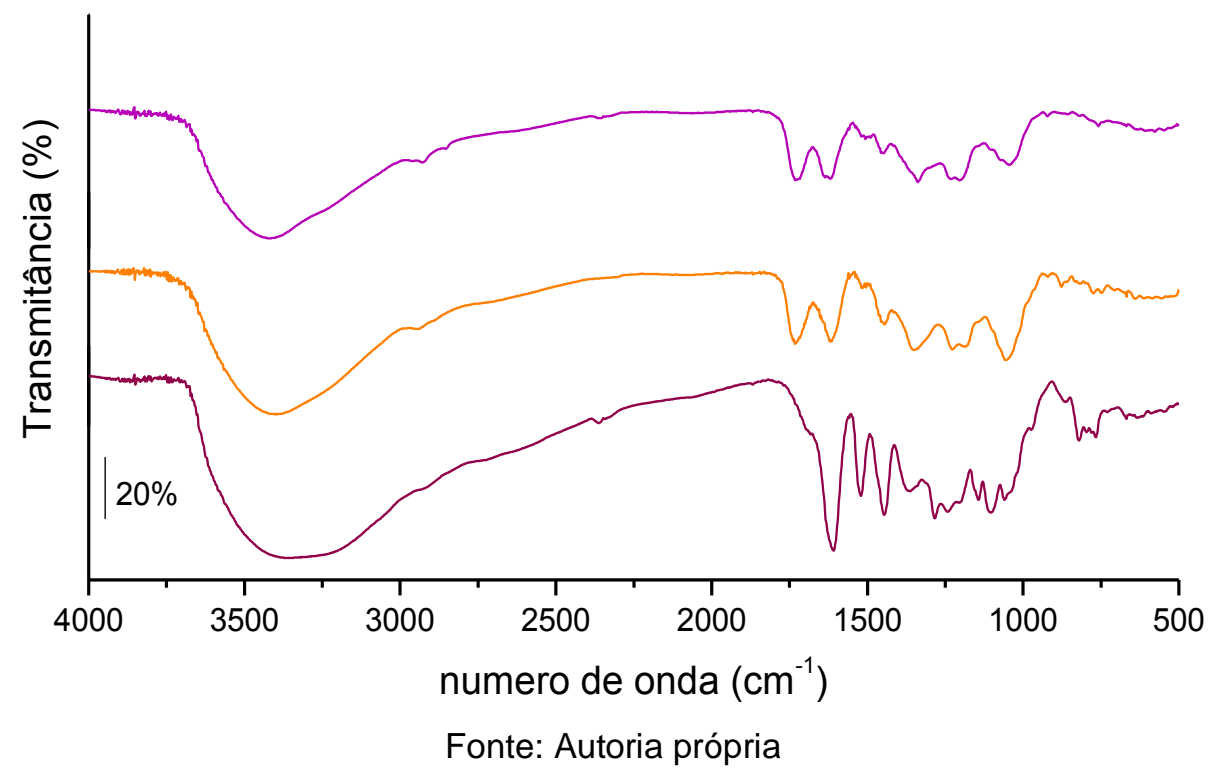

Tabela 2: Bandas no FTIR observadas nos espectros dos extratos

\begin{tabular}{ccc}
\multicolumn{3}{c}{ Número de onda $\left(\mathbf{c m}^{-1}\right)$} \\
\hline Semente de uva & Casca de romã & Casca de jabuticaba \\
\hline- & 1728 & 1737 \\
1614 & 1616 & 1616 \\
1521 & 1516 & 1506 \\
1446 & 1452 & 1452 \\
1365 & 1350 & 1340 \\
1282 & - & - \\
1244 & 1230 & 1232 \\
1043 & 1051 & 1045 \\
\hline
\end{tabular}

Próximo aos picos em $1045 \mathrm{~cm}^{-1}$ observou-se a deformação dos grupos C$\mathrm{H}$ do anel aromático e grupos $\mathrm{O}-\mathrm{H}$. No extrato de semente de uva, observou-se uma banda em $1285 \mathrm{~cm}^{-1}$ corresponde ao estiramento C-O decorrente da estrutura do anel pirano, presentes nos taninos. Uma banda deslocada para menor número de onda aparece de maneira similar nos extratos de romã e jabuticaba em 1230 e $1228 \mathrm{~cm}^{-1}$ (Nascimento, 2011). 


\subsection{Análise da concentração de flavonoides totais}

A curva de calibração (Figura 19) para a determinação do teor total de flavonoides presentes nos extratos de jabuticaba e romã forneceu a equação de reta expressa por $\mathrm{y}=0,00488+0,00337 x$, em que y é a absorbância e $\mathrm{x}$ a concentração de quercetina em $\mu \mathrm{g} \mathrm{mL}^{-1}$, com $\mathrm{R}^{2}=0,9978$.

Figura 19: Curva de calibração de quercetina

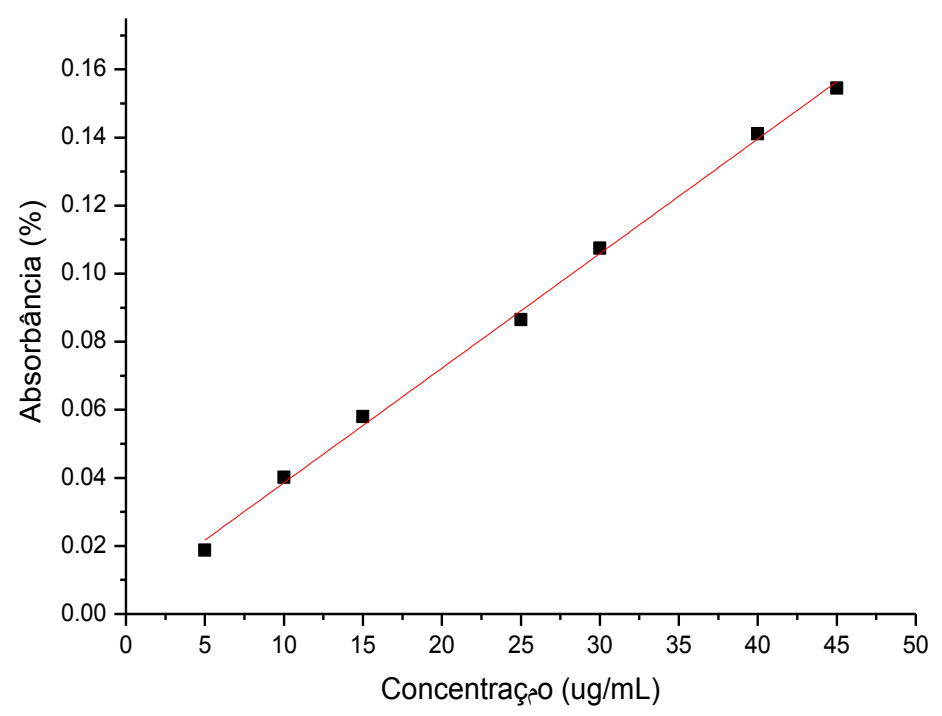

Fonte: Autoria própria

Para análise no espectrofotômetro UV-Vis, é utilizado o nitrato de alumínio como fonte do íon alumínio $\mathrm{Al}^{3+}$, que forma um complexo estável com flavonoides denominado flavonoide- $\mathrm{Al}^{3+}$, conforme mostra a Figura 20. Essa complexação promove o denominado deslocamento batocrômico, que é o deslocamento da absorção para uma região de maior comprimento de onda (ou "deslocamento para o vermelho"), o que ocasiona a intensificação da absorção na região de $425 \mathrm{~nm}$ de diferentes flavonoides e possibilita a quantificação do complexo sem a interferência de outros componentes fenólicos da amostra (Mabry et al., 1970).

Para o extrato de casca de romã, foi obtido um valor médio de $60,13 \pm 2,44 \mathrm{mg}$ QE / g extrato, semelhante a Monein (2012) que preparou um extrato de casca de romã a partir da extração em metanol e obteve 59,44 $\pm 3,71$ mg QE / g, indicando que a mudança no solvente não influencia na extração dos flavonoides. 
Figura 20: Complexação do flavonoide quercetina pelo $\mathrm{AlCl}_{3}$, gerando o complexo quercetina-Al ${ }^{3+}$<smiles>O=c1c(O)c(-c2ccc(O)c(O)c2)oc2cc(O)cc(O)c12</smiles>

Fonte: Adaptado de Mabry et al. (1970)

Derakhshan et al. (2018) prepararam extratos de casca de romã a partir de uma solução hidroetanólica $80 \%$ e analisaram a quantidade de flavonoides totais a partir de um padrão de rutina. Com isso, obtiveram valores não superiores a $45 \pm$ 9,84 mg de rutina/g indicando que apesar do padrão diferente, não houve grande variação na quantidade de flavonoides da romã utilizando-se a extração em meio hidroetanólico.

Para o extrato de casca de jabuticaba, foi obtido valor médio de 25,65 $\pm 2,73 \mathrm{mg}$ QE / g extrato, maior que o apresentado por Pitz et al. (2017), que fez a extração em solução hidroetanólica $50 \%$ pH 3,6 por 3h e obteve valor de 8,7 \pm 0,16 mg QE / g. Essa redução pode ser decorrente do menor tempo de extração, já que em solventes etanólicos e metanólicos a quantidade de compostos polifenólicos no extrato aumenta com o tempo de extração, conforme afirmam Lapornik et al. (2005).

\subsection{Espectroscopia por energia dispersiva de raios X (EDX)}

A relação cálcio/fosforo do fosfato de cálcio foi obtida pelo EDX, sendo $1,60 \pm 0,03$. De acordo com Aparecida et al. (2007) o valor se aproxima mais da hidroxiapatita $(\mathrm{Ca} / \mathrm{P}=1,67)$ do que de apatitas amorfas $(\mathrm{Ca} / \mathrm{P}=1,50)$ e do fosfato tetracálcico $(\mathrm{Ca} / \mathrm{P}=2,0)$. No corpo humano, a hidroxiapatita pode variar sua razão $\mathrm{Ca} / \mathrm{P}$ dependendo de sua localização e idade do osso, podendo variar de 1,37 a 1,87 (Brown e Constantz, 1994; Mucalo, 2015). 
Pela Figura 21, observa-se também a presença de pequenos picos referentes ao sódio em 1,02 keV, ao cloro em 2,62 keV e ao potássio em 3,30 keV. Esses elementos químicos estão presentes devido aos precursores da síntese da hidroxiapatita, na forma de $\mathrm{K}_{2} \mathrm{HPO}_{4}, \mathrm{NaOH}$ e $\mathrm{CaCl}_{2}$.

Figura 21: Espectro EDX do fosfato de cálcio

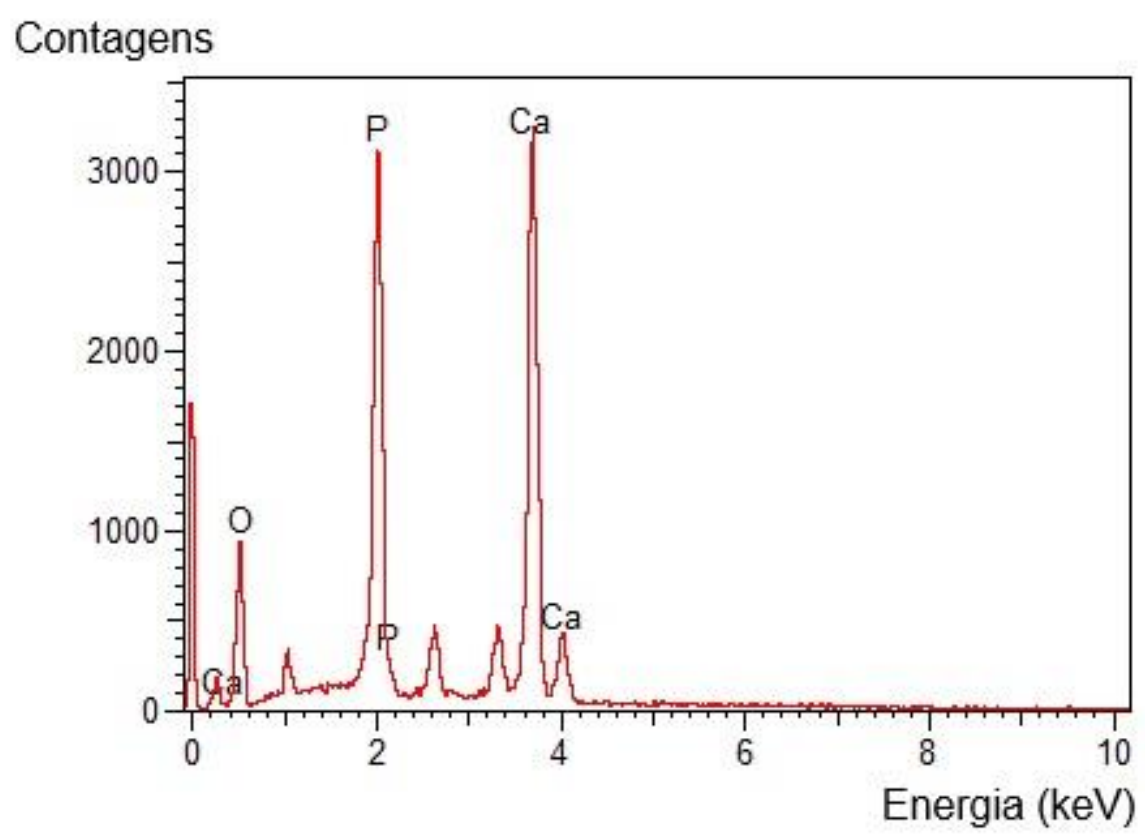

Fonte: Autoria própria

\subsection{Difração de Raios-X (DRX)}

O difratograma (Figura 22) apresenta picos de difração característicos com o padrão JCPDS 9-0432, confirmando que o fosfato de cálcio sintetizado é a hidroxiapatita. Também são observados picos de difração de $\mathrm{NaCl}$ e $\mathrm{KCl}$ no difratograma da hidroxiapatita, mostrando a presença desses sais juntos à biocerâmica. 
Figura 22: Difratograma da (A) hidroxiapatita sintetizada com picos de $(\bullet) \mathrm{NaCl}$ e $(\diamond) \mathrm{KCl}$, e (B) hidroxiapatita JCPDS 9-0432

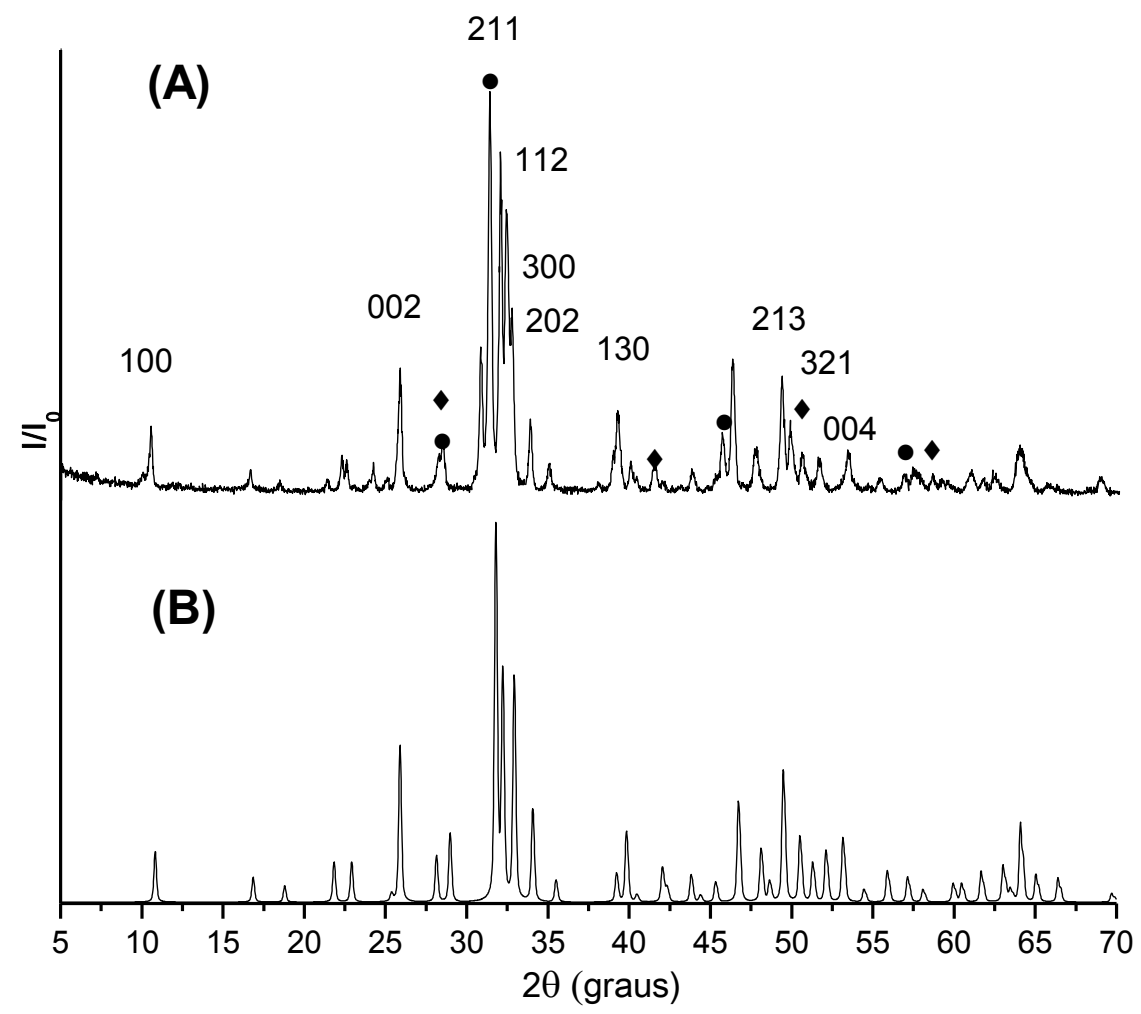

Fonte: Autoria própria

A Tabela 3 mostra a relação dos principais planos da hidroxiapatita comparados com a literatura (Shahabi et al., 2014).

Tabela 3: Comparação entre os valores de $2 \theta$ da hidroxiapatita sintetizada com os obtidos da literatura

\begin{tabular}{ccc}
\hline \multirow{2}{*}{$\begin{array}{c}\text { Planos } \\
\text { Cristalográficos }\end{array}$} & \multicolumn{2}{c}{$\mathbf{2 \theta \text { (graus) }}$} \\
\cline { 2 - 3 } 002 & 25,82 & 25,87 \\
211 & 31,34 & 31,77 \\
112 & 32,00 & 32,19 \\
300 & 32,72 & 32,90 \\
202 & 33,84 & 34,05 \\
310 & 39,20 & 39,82 \\
222 & 46,24 & 46,71 \\
213 & 49,28 & 49,47 \\
321 & 50,48 & 50,49 \\
004 & 53,30 & 53,14 \\
\hline
\end{tabular}

* Shahabi et al (2014) 
Através do difratograma e da equação de Scherrer, foi possível calcular o tamanho do grão cristalino, também conhecido como cristalito, da hidroxiapatita como sendo da ordem de $38,9 \mathrm{~nm}$. Também foi possível calcular o percentual de cristalinidade como sendo de 80,4\%.

Embora o tamanho do cristalito e do percentual de cristalinidade dependa dos reagentes e da rota de síntese, Mobasherpour et al. (2007) e Monshi et al. (2012) mostraram que é possível aumentar esse tamanho e o percentual com o aumento do tratamento térmico do pó de hidroxiapatita. Para Sarfraz et al. (2011), o tamanho do grão também pode aumentar com o aumento da concentração de CTAB utilizado na síntese. Para a concentração de $0,01 \mathrm{~mol} \mathrm{~L}^{-1}$ de CTAB, mesma concentração utilizada neste trabalho, eles obtiveram tamanho de cristalito igual a 3,27 nm, quase 12 vezes menor do que o obtido neste trabalho.

\subsection{Calorimetria exploratória diferencial (DSC)}

\subsubsection{DSC do colágeno}

A transição observada no DSC ocorre devido ao aquecimento, podendo ser definida como a transição da hélice tripla do colágeno para uma forma em que as ligações cruzadas da estrutura terciária são quebradas, passando de uma estrutura altamente organizada a um estado desorganizado denominado de gelatina (Parenteau-Bareil et al., 2010; Liu et al., 2015). A temperatura de desnaturação do colágeno presente na matriz após o processo de hidrólise e antes da solubilização em ácido acético foi $48,6^{\circ} \mathrm{C}$, o que indica que o processo de hidrólise por $120 \mathrm{~h}$ não desnatura o colágeno.

\subsubsection{DSC das matrizes}

Os valores das temperaturas de desnaturação do colágeno das matrizes neutras estão dispostos na Tabela 4.

Observa-se um aumento na temperatura de desnaturação das matrizes que contém extrato (CP, CR e CJ) em relação à matriz sem $(C)$, indicando que os extratos, abundantes em flavonoides, atuam como agentes de reticulação do biopolímero. A matriz com extrato de semente de uva apresentou maior temperatura de desnaturação, variando $11^{\circ} \mathrm{C}$ em relação à matriz $\mathrm{C}$, ou seja, a reticulação foi mais 
efetiva. As matrizes CR e CJ apresentam praticamente a mesma Td observando-se um aumento menor do que $5^{\circ} \mathrm{C}$.

Tabela 4: Valores da temperatura de desnaturação $\left(\mathrm{Td}^{\circ} \mathrm{C}\right)$ para as matrizes

\begin{tabular}{cc} 
Matriz & $\operatorname{Td}\left({ }^{\circ} \mathbf{C}\right)$ \\
\hline C & 47,6 \\
CP & 59,2 \\
CR & 52,8 \\
CJ & 53,2 \\
CnHA & 47,9 \\
CnHAP & 56,6 \\
CnHAR & 52,8 \\
CnHAJ & 52,2 \\
\hline
\end{tabular}

Os flavonoides são um conjunto de moléculas que podem apresentar diversos grupos hidroxilas. Esses grupos conseguem formar ligações de hidrogênio entre os agrupamentos amida dos resíduos de prolina presentes na hélice tripla do colágeno, promovendo a reticulação do biopolímero como observado em todos os casos (Carvalho, 2007).

Para as matrizes com hidroxiapatita, não foi observada diferença na temperatura de desnaturação quando comparadas as respectivas matrizes sem extrato, indicando que a adição de hidroxiapatita nas matrizes não influencia a temperatura de desnaturação do biopolímeros.

\subsection{Microscopia eletrônica de varredura (MEV)}

\subsubsection{MEV da nanohidroxiapatita}

A fotomicrografia mostrada na Figura 23 revela morfologia típica de aglomerados de hidroxiapatita (Sarfraz et al., 2011), sendo observado o maior diâmetro horizontal $\left(\mathrm{d}_{H}\right)$ de $454,8 \mathrm{~nm}$ e o menor de $53,8 \mathrm{~nm}$. A média de 50 determinações considerando apenas o $d_{H}$ foi de 168,6 \pm 92,8 nm. 
Figura 23: Fotomicrografia por MEV da hidroxiapatita

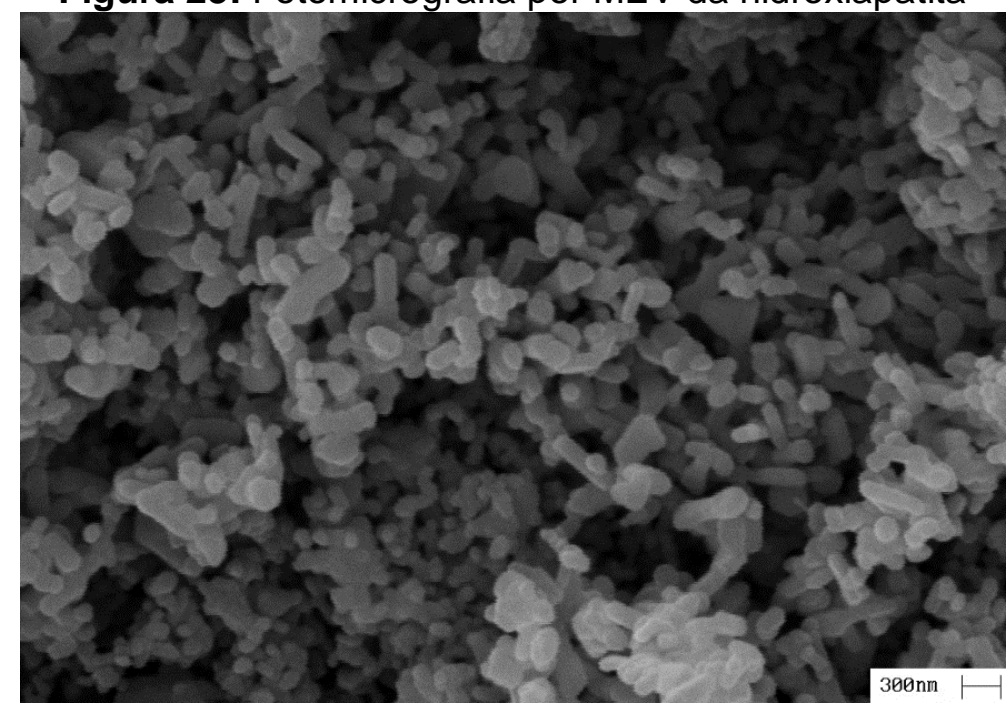

Fonte: Autoria própria

A escala nanométrica que caracteriza uma nanoparticula não é um consenso entre diversos autores. Sun et al. (2012) consideram nanopartículas como sendo partículas de tamanho entre 10 a 1000 nm. Para Giannitrapani et al. (2014) e Dhbohlavova et al. (2013), a escala nano varia de 10 a $500 \mathrm{~nm}$ e de 10 a $200 \mathrm{~nm}$ respectivamente, enquanto para Li et. al. (2017), nanopartículas podem ter tamanho entre 100 e 200 nm. Pela faixa apresentada por esses autores, a hidroxiapatita sintetizada se encontra na escala nano.

O Centro de Direito Ambiental Internacional (Center for International Environmental Law - CIEL) apresenta uma definição de nanomaterial mais abrangente. Eles afirmam que o valor máximo de $100 \mathrm{~nm}$ é um limitador arbitrário e não cientifico, além de enfatizar que até aglomerados ou agregados com mais de 100 $\mathrm{nm}$ podem ser considerados nanomateriais, pois as propriedades apresentadas são as mesmas observadas para nanomateriais. Esses agregados também podem se decompor em suas partículas primárias dependendo de condições externas (CIEL, 2014).

A ISO/TS 80004-2:2015 define nanopartícula como um material que apresenta as três dimensões entre 1 e 100 nm. Um nano-objeto também é definido nessa norma como sendo um material que possui uma ou mais dimensões na nano escala. Outra norma ISO é a ISO/TR 18401:2017 que mostra a definição de nanomaterial como sendo qualquer material que apresente qualquer dimensão em nanoescala $(1-100 \mathrm{~nm})$. 
Apesar do diâmetro medido dos aglomerados estar fora da escala nano pelas normas acima, a medida perpendicular desse diâmetro (diâmetro vertical) é de $98,4 \pm 33,6 \mathrm{~nm}$ (para 50 determinações), ou seja, dentro da escala nano e caracterizando assim a hidroxiapatita sintetizada como sendo um nano-objeto ou nanomaterial. O maior e o menor dv observados são de 41,7 e 228,9 nm.

A Figura 24 mostra a distribuição das 50 medias de diâmetros horizontais e verticais da nanohidroxiapatita. Observa-se maior distribuição de tamanhos na posição horizontal do que na vertical, que apresenta moda na região de 50 a $100 \mathrm{~nm}$.

A importância de se obter um menor tamanho de partícula deve-se ao aumento da superfície em relação ao volume, o que gera um aumento na sorção de proteínas e adesão celular por matrizes compostas de colágeno e nanohidroxiapatita (Ghomi et al., 2011; Elhendawi et al., 2014).

Figura 24: Histograma da distribuição do tamanho dos diâmetros dos aglomerados na nanohidroxiapatita: $(\mathbf{A})$ horizontais e $(\mathbf{B})$ verticais

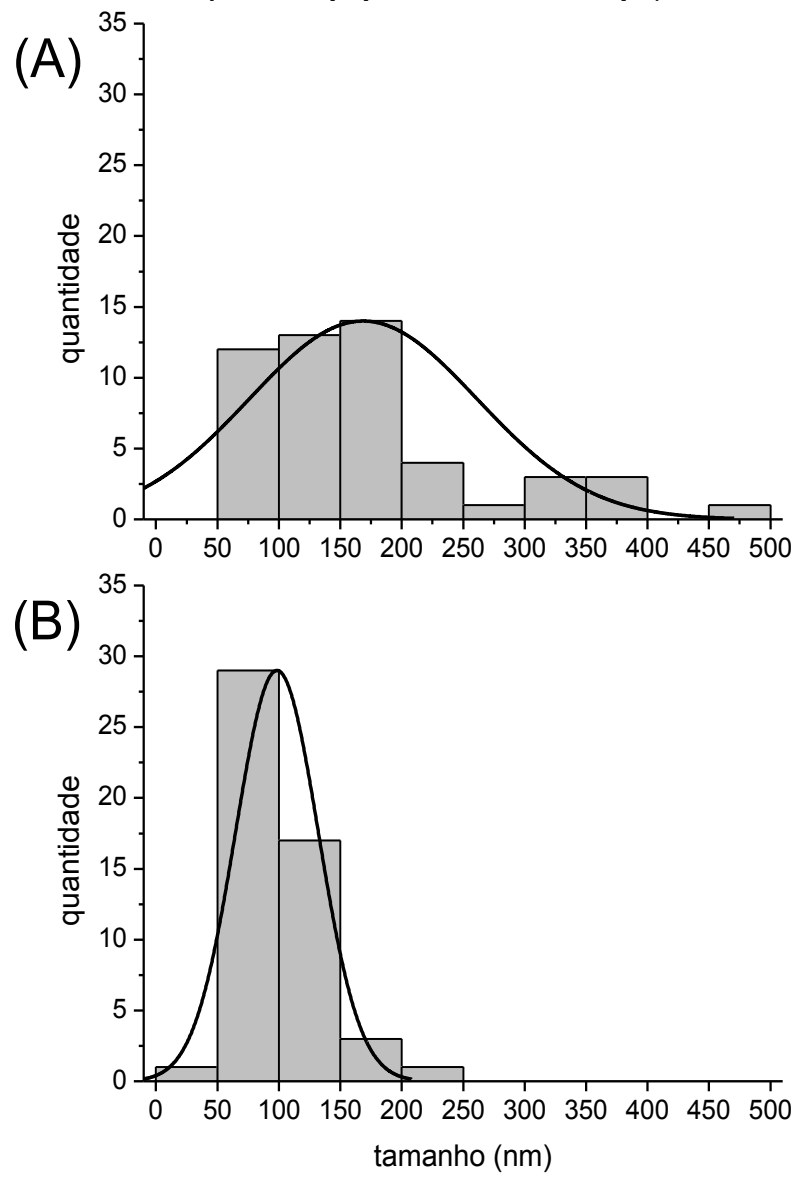

Fonte: Autoria própria 


\subsubsection{MEV das matrizes}

O tamanho dos poros, a interconectividade e a porosidade das matrizes são de extrema importância para a regeneração tecidual, pois facilitam a proliferação, migração e diferenciação celular, permitindo transporte de oxigênio e nutrientes dentro da estrutura (Bartolo et al., 2011; Nyberg et al., 2017).

As fotomicrografias mostram superfícies porosas para as matrizes $\mathrm{CP}, \mathrm{CR}$, CJ, CnHA e CnHAP e também poros internos (ou canais) desorganizados. A grande variação no tamanho dos poros pode ser vista pelos histogramas e pelas Tabelas 5 e 6, que apresentam o tamanho do menor e maior poro, assim como a média e o coeficiente de variação.

Tabela 5: Valores do tamanho médio, do maior e do menor poro da superfície das fotomicrografias por MEV das matrizes

\begin{tabular}{ccccc}
\hline \multirow{2}{*}{ Matriz } & \multicolumn{4}{c}{ Tamanho do poro da superfície } \\
\cline { 2 - 5 } & Menor $(\boldsymbol{\mu m})$ & Maior $(\boldsymbol{\mu m})$ & Média \pm dp $(\boldsymbol{\mu m})$ & $\mathbf{C v}(\%)$ \\
\hline C & - & - & - & - \\
CP & 23,0 & 112,9 & $56,3 \pm 23,9^{\mathrm{b}, \mathrm{c}}$ & 42,4 \\
CR & 32,1 & 449,9 & $126,1 \pm 118,6^{\mathrm{a}}$ & 94,0 \\
CJ & 20,3 & 223,7 & $72,8 \pm 47,1^{\mathrm{b}}$ & 64,7 \\
CnHA & 15,3 & 47,9 & $28,1 \pm 7,5^{\mathrm{c}}$ & 26,6 \\
CnHAP & 16,0 & 128,0 & $47,1 \pm 24,2^{\mathrm{b}, \mathrm{c}}$ & 51,4 \\
CnHAR & - & - & - & - \\
CnHAJ & - & - & - & - \\
\hline
\end{tabular}

$\mathrm{Na}$ tabela, letras iguais significam valores estatisticamente iguais $(p<0,05)$.

Tabela 6: Valores do Tamanho médio, do menor e do maior poro interno (canais) das fotomicrografias por MEV das matrizes

\begin{tabular}{ccccc}
\hline \multirow{2}{*}{ Matriz } & \multicolumn{4}{c}{ Tamanho dos canais internos } \\
\cline { 2 - 5 } & Menor $(\boldsymbol{\mu m})$ & Maior $(\boldsymbol{\mu m})$ & Média $\pm \mathbf{s d}(\boldsymbol{\mu m})$ & $\mathbf{C v}(\%)$ \\
\hline C & 17,0 & 213,2 & $58,3 \pm 28,7^{\mathrm{d}, \mathrm{e}}$ & 49,3 \\
CP & 23,0 & 220,2 & $60,9 \pm 33,8^{\mathrm{c}, \mathrm{d}, \mathrm{e}}$ & 55,4 \\
CR & 31,0 & 169,9 & $69,9 \pm 26,7^{\mathrm{b}, \mathrm{c}, \mathrm{d}}$ & 38,2 \\
CJ & 26,9 & 202,8 & $80,9 \pm 45,1^{\mathrm{a}, \mathrm{d}}$ & 55,8 \\
CnHA & 20,2 & 67,8 & $34,7 \pm 12,5^{\mathrm{e}}$ & 36,1 \\
CnHAP & 34,9 & 226,8 & $97,6 \pm 55,6^{\mathrm{a}}$ & 56,9 \\
CnHAR & 24,0 & 182,7 & $87,0 \pm 38,0^{\mathrm{a}, \mathrm{c}}$ & 43,7 \\
CnHAJ & 34,9 & 229,5 & $89,4 \pm 43,2^{\mathrm{a}, \mathrm{b}}$ & 48.4 \\
\hline
\end{tabular}

$\mathrm{Na}$ tabela, letras iguais significam valores estatisticamente iguais $(p<0,05)$. 
A Figura 25 mostra a superfície e a secção transversal com o histograma da matriz C. Observa-se que a superfície apresenta rugosidade semelhante ao formato de um poro, entretanto não é visível uma interconectividade entre a superfície externa com o interior da matriz. Os poros no interior da matriz são de tamanho variado, tendo coeficiente de variação de 49,3\% e apresentando um sistema bimodal, com maior frequência de tamanho de poros de 30 a $40 \mu \mathrm{m}$ e de 40 a $50 \mu \mathrm{m}$.

Figura 25: Matriz C: A) Fotomicrografia por MEV da superfície; B) Histograma da secção transversal; C) Fotomicrografia por MEV da secção transversal

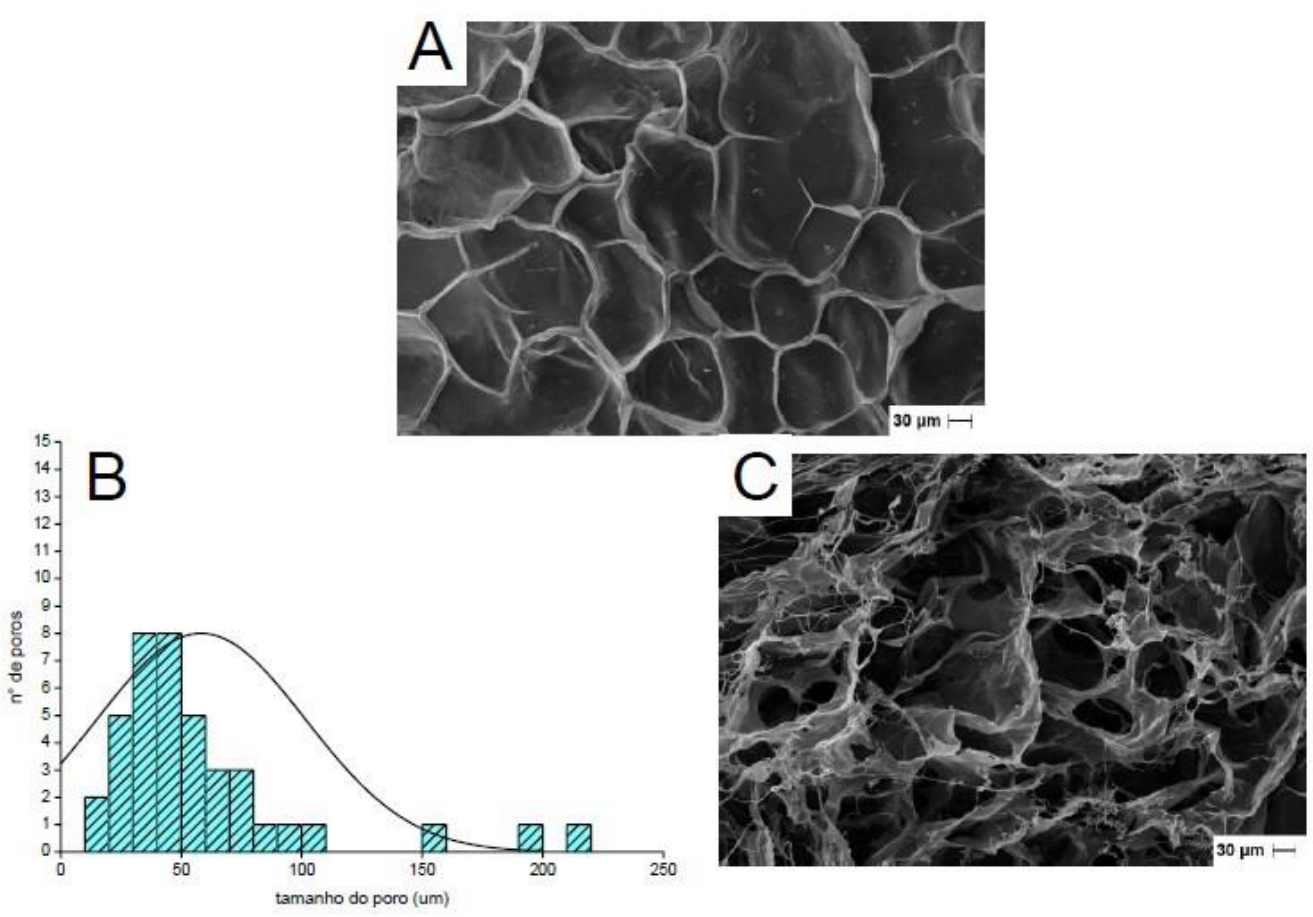

Fonte: Autoria própria

Comparando a matriz C com a CP, CR e CJ, observa-se que a adição de extrato resulta em poros na superficie da estrutura. A matriz CP (Figura 26) apresenta poros de tamanhos mais regulares na superficie, apresentando menor coeficiente de variação dentre essas três (42,4\%), diferente da matriz CR (Figura 27) que apresenta maior tamanho de poro $(449,8 \mu \mathrm{m})$ e maior variação no tamanho de poros $(\mathrm{Cv}=94,0 \%)$.

Os poros da superficie dessas duas matrizes apresentam interconectividade entre eles e entre os poros do interior da matriz. Diferentemente, os poros da superficie da matriz CJ (Figura 28) apresentam morfologia irregular e aparentam ter menor conectividade com os poros do interior da matriz. A análise 
estatística mostrou que os poros da superfície de CP e CJ são iguais, mas ambos são diferentes da matriz CR.

Na secção transversal, a matriz CJ apresentou tamanho de poros mais variados ( $C v=55,8 \%)$ e não foi observada diferença estatística entre os poros internos das matrizes C, CP, CR e CJ.

Figura 26: Matriz CP: A) Histograma dos poros da superficie; B) Fotomicrografia por MEV da superficie; C) Histograma dos poros da secção transversal;

D) Fotomicrografia por MEV da secção transversal
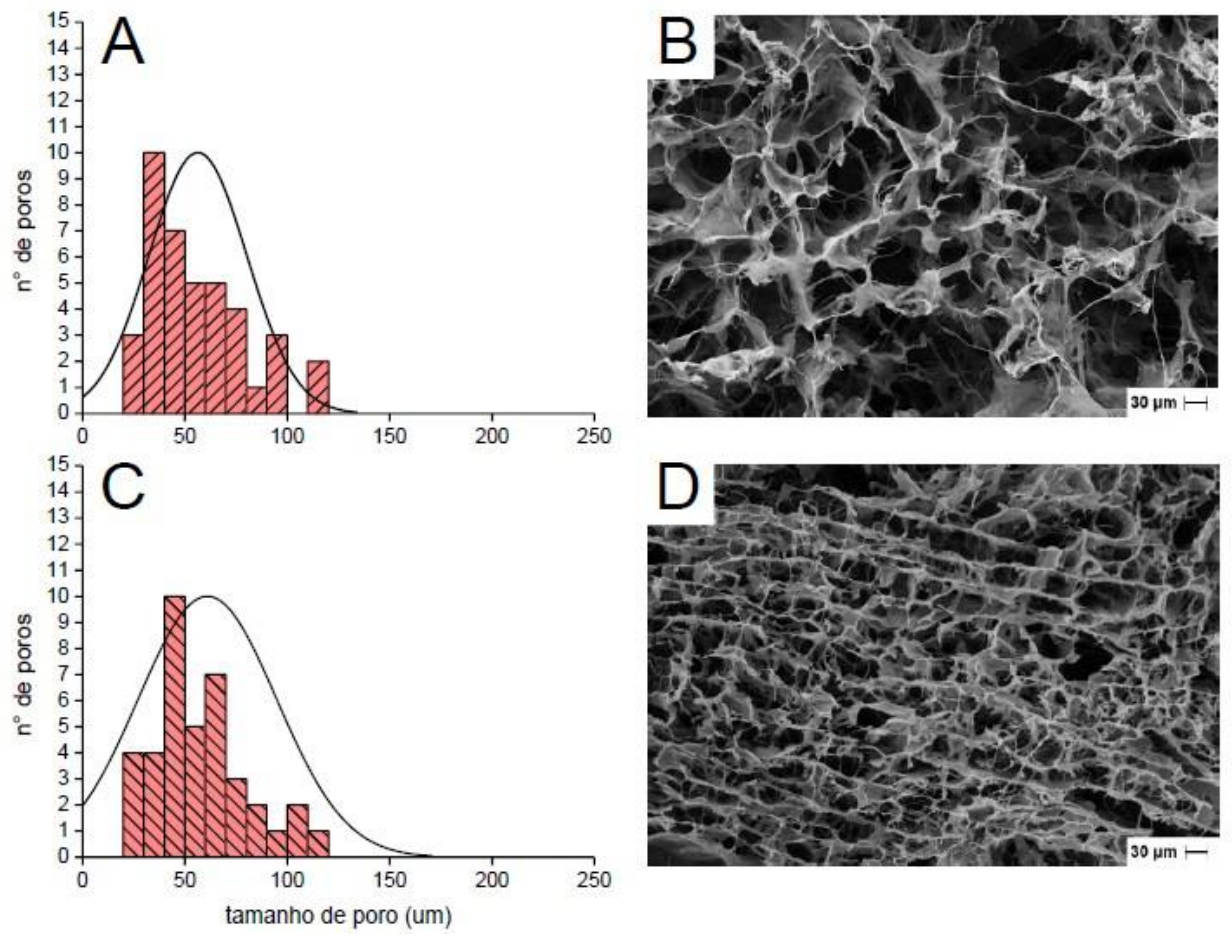

Fonte: Autoria própria 
Figura 27: Matriz CR: A) Histograma dos poros da superficie; B) Fotomicrografia por MEV da superficie; C) Histograma dos poros da secção transversal;

D) Fotomicrografia por MEV da secção transversal
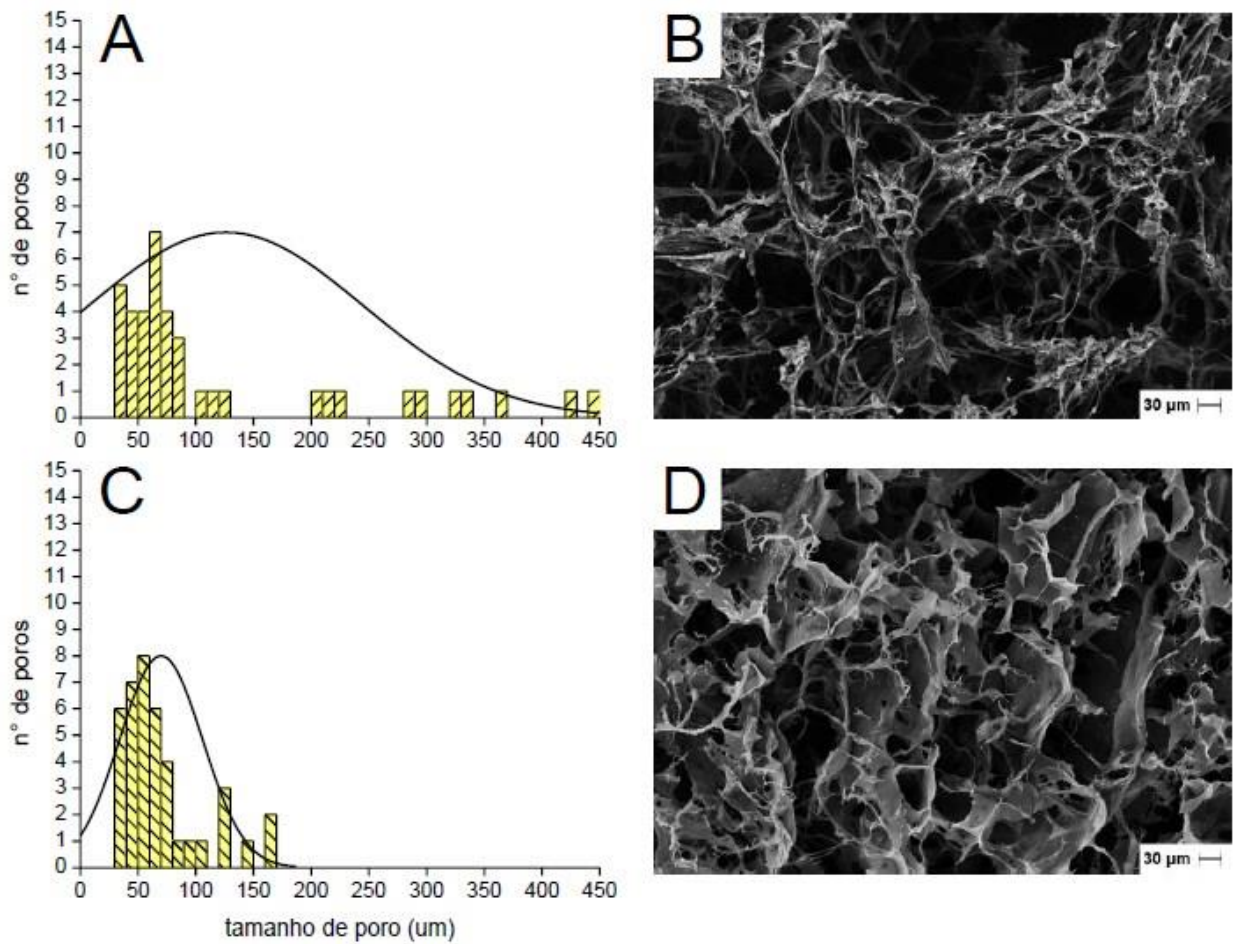

Fonte: Autoria própria

Figura 28: Matriz CJ: A) Histograma dos poros da superficie; B) Fotomicrografia por MEV da superficie; C) Histograma dos poros da secção transversal;

D) Fotomicrografia por MEV da secção transversal

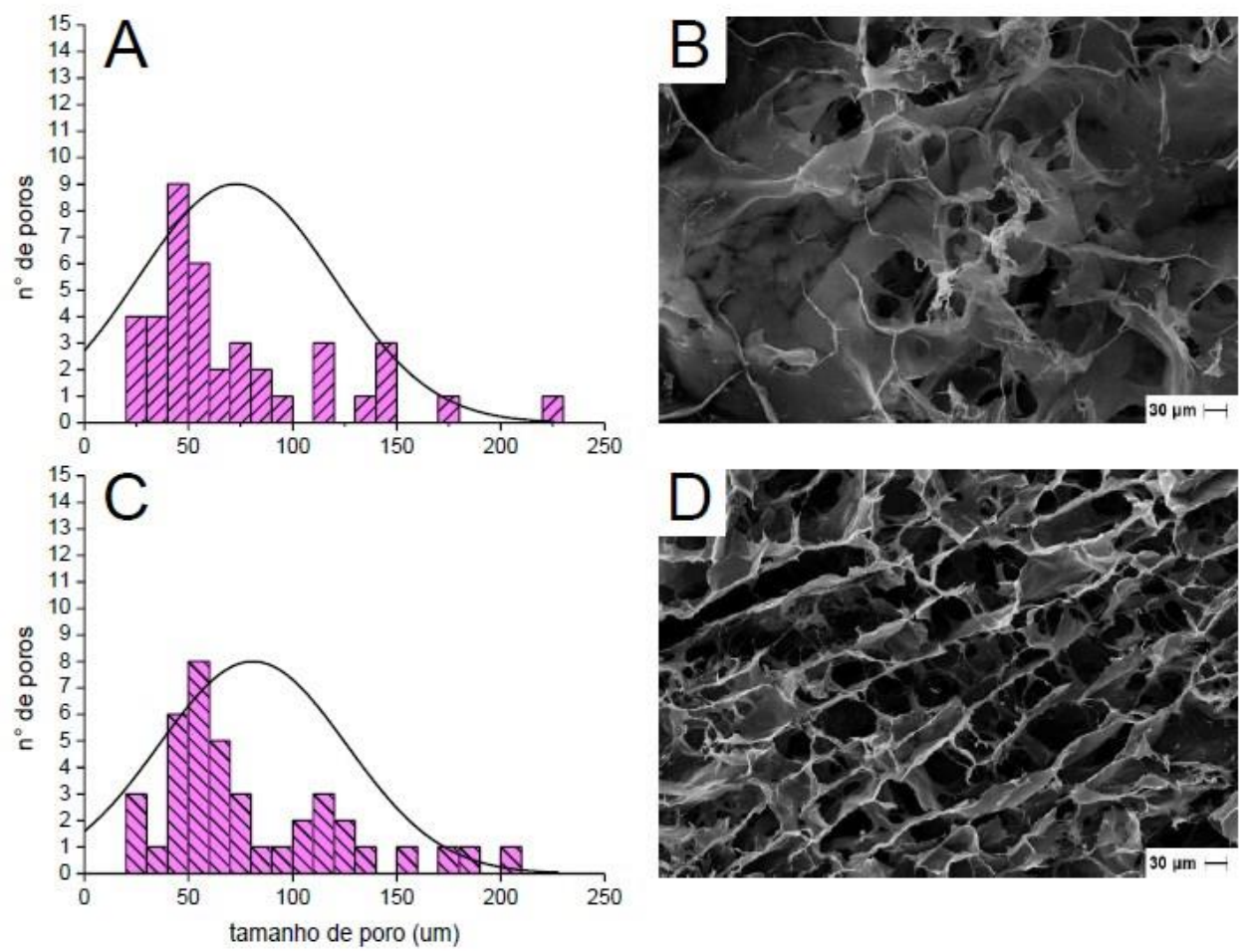

Fonte: Autoria própria 
A Figura 29 mostra as fotomicrografias e histogramas referentes a matriz CnHA. Comparando-a com a matriz C, observa-se que a adição de hidroxiapatita ocasiona no aparecimento de pequenos poros espaçados e de tamanho regular na superfície, sendo que essa matriz apresentou o menor coeficiente de variação (26,6\%) dentre todas as oito, e consequentemente, maior regularidade no tamanho de poros. $\mathrm{Na}$ secção transversal, não foi observada diferença estatística entre o tamanho de poro dessas duas matrizes.

Na Figura 29 B, também é possível notar a presença de pequenos aglomerados de nanohidroxiapatita. Esses aglomerados na superfície da matriz CnHA, também são encontrados na superfície das demais matrizes com nanohidroxiapatita.

Figura 29: Matriz CnHA: A) Histograma dos poros da superficie; B) Fotomicrografia por MEV da superficie; C) Histograma dos poros da secção transversal;

D) Fotomicrografia por MEV da secção transversal
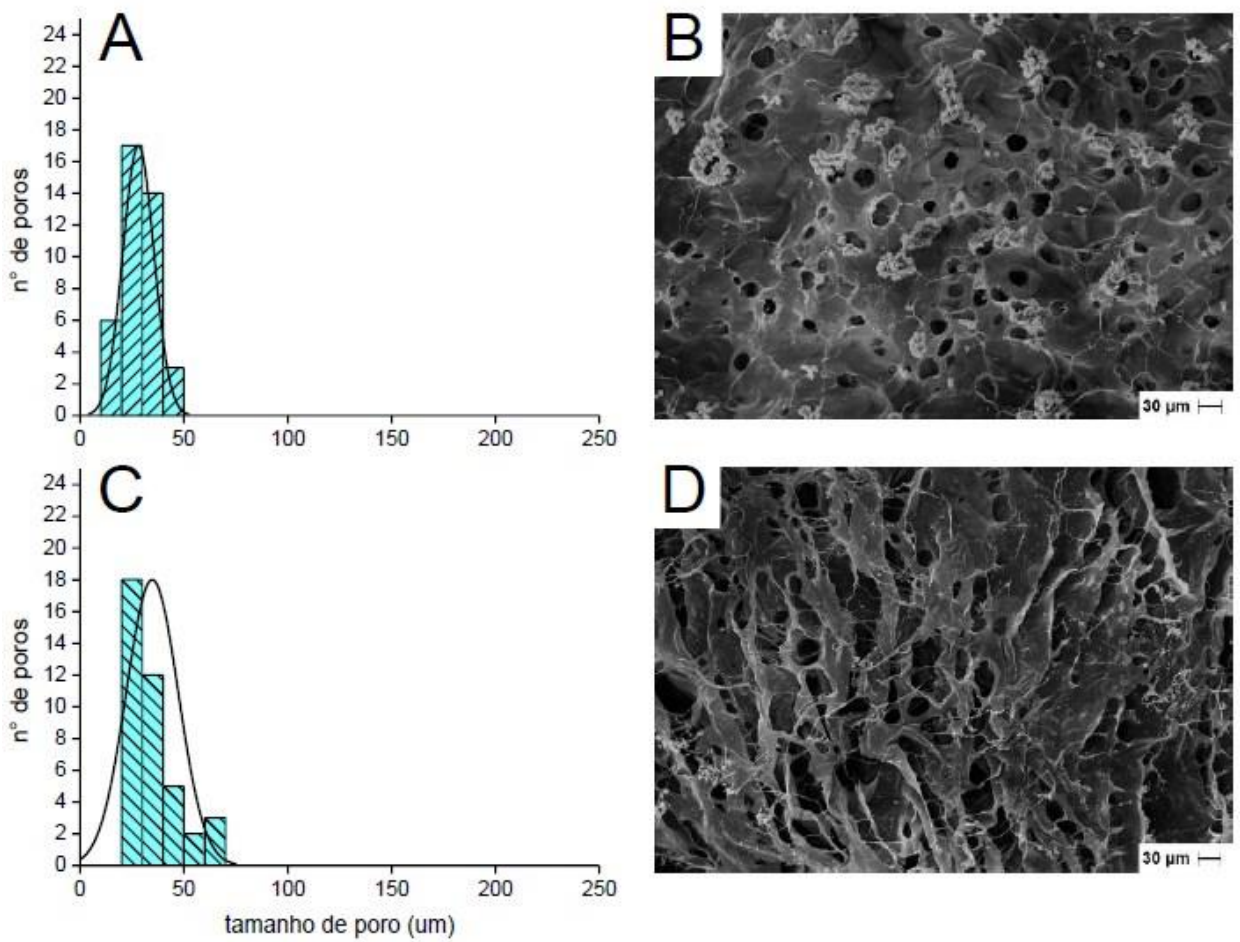

Fonte: Autoria própria

A matriz CnHAP (Figura 30) apresenta poros desorganizados em sua superfície e na secção transversal, sendo que os poros superficiais aparentam ser conectados entre si e com os poros internos. Isso não ocorre para as matrizes CnHAR (Figura 31) e CnHAJ (Figura 32), que apresentam superfícies rugosas. 
A matriz CnHAR apresenta ausência total de poros em sua superfície sendo observado uma superfície rugosa e que não há conectividade entre a superfície externa com o interior da matriz. Diferente desta, a matriz CnHAJ apresenta alguns poros de 33,5 \pm 9,6 $\mu \mathrm{m}$ (15 determinações) em sua superfície, entretanto, devido à baixa quantidade de poros e suas distâncias, sua superfície foi considerada apenas rugosa e não porosa.

As matrizes CnHAP, CnHAR e CnHAJ, não apresentaram diferença estatística entre os poros da secção transversal, entretanto essas três são diferentes da matriz $\mathrm{CnHA}$ e $\mathrm{C}$, indicando que a adição $\mathrm{nHA}$ junto ao extrato aumenta o tamanho de poro interno das matrizes.

Figura 30: Matriz CnHAP: A) Histograma dos poros da superficie; B) Fotomicrografia por MEV da superficie; C) Histograma dos poros da secção transversal;

D) Fotomicrografia por MEV da secção transversal

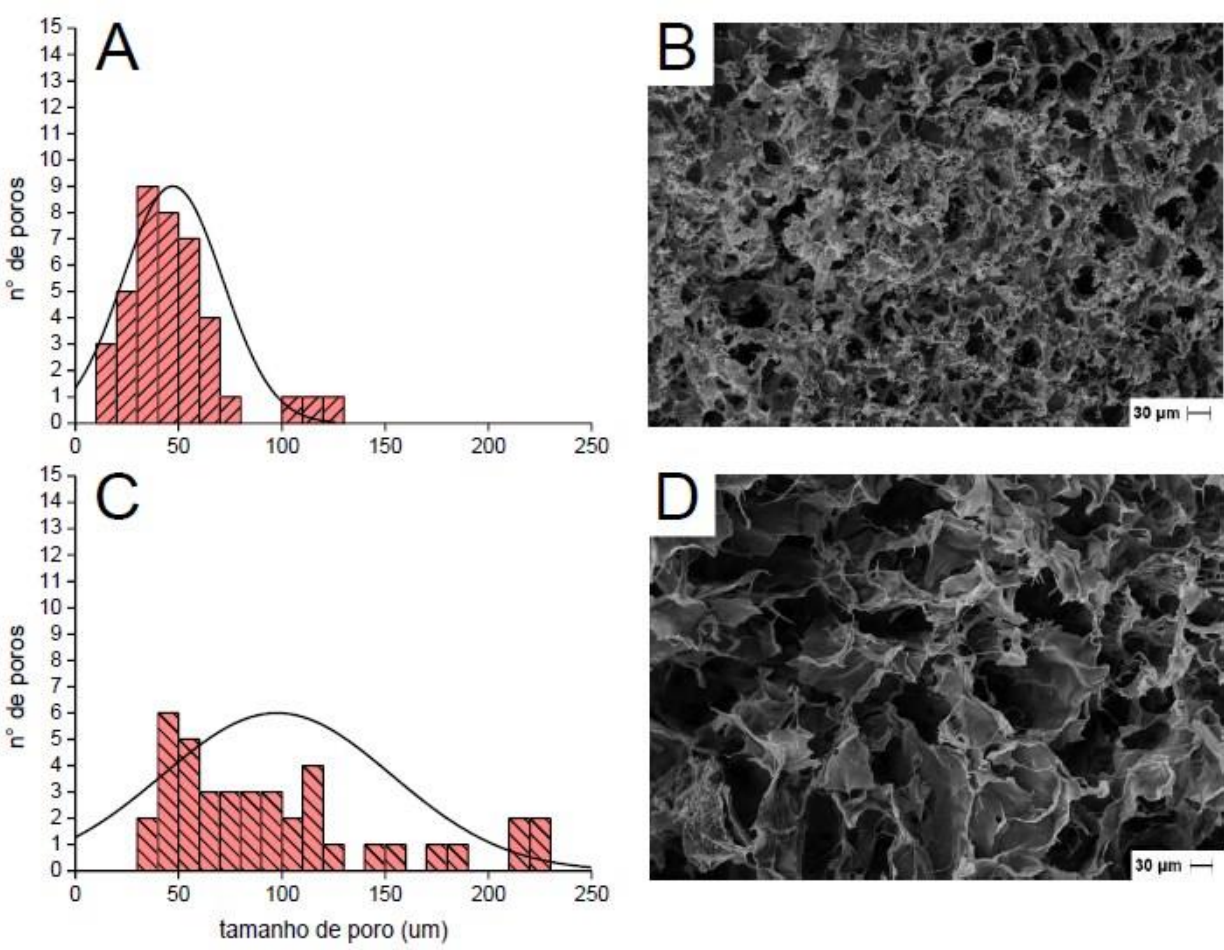

Fonte: Autoria própria 
Figura 31: Matriz CnHAR: A) Fotomicrografia por MEV da superfície;

B) Histograma da secção transversal; C) Fotomicrografia por MEV da secção transversal

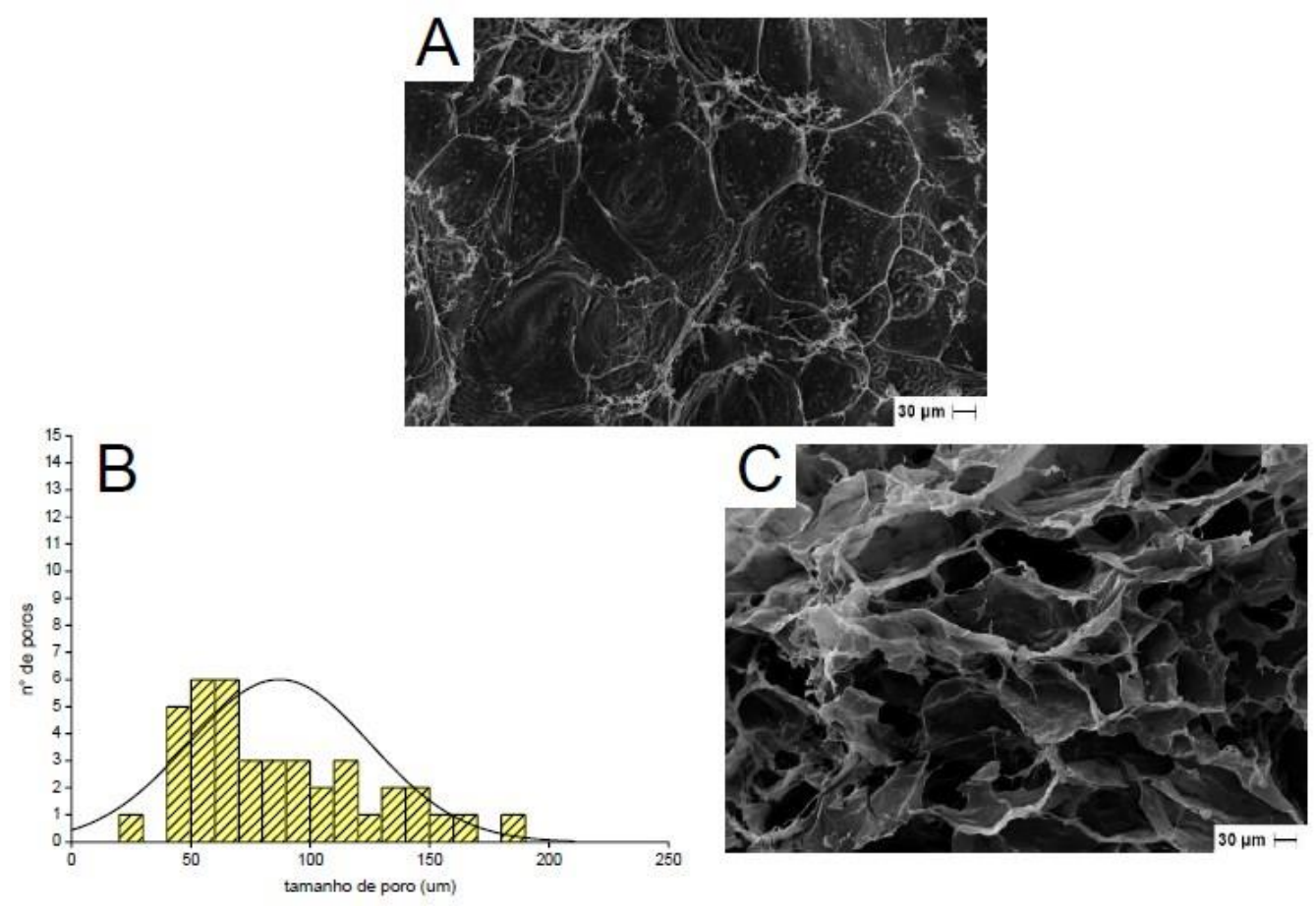

Fonte: Autoria própria

Figura 32: Matriz CnHAJ: A) Fotomicrografia por MEV da superfície;

B) Histograma da secção transversal; C) Fotomicrografia por MEV da secção transversal

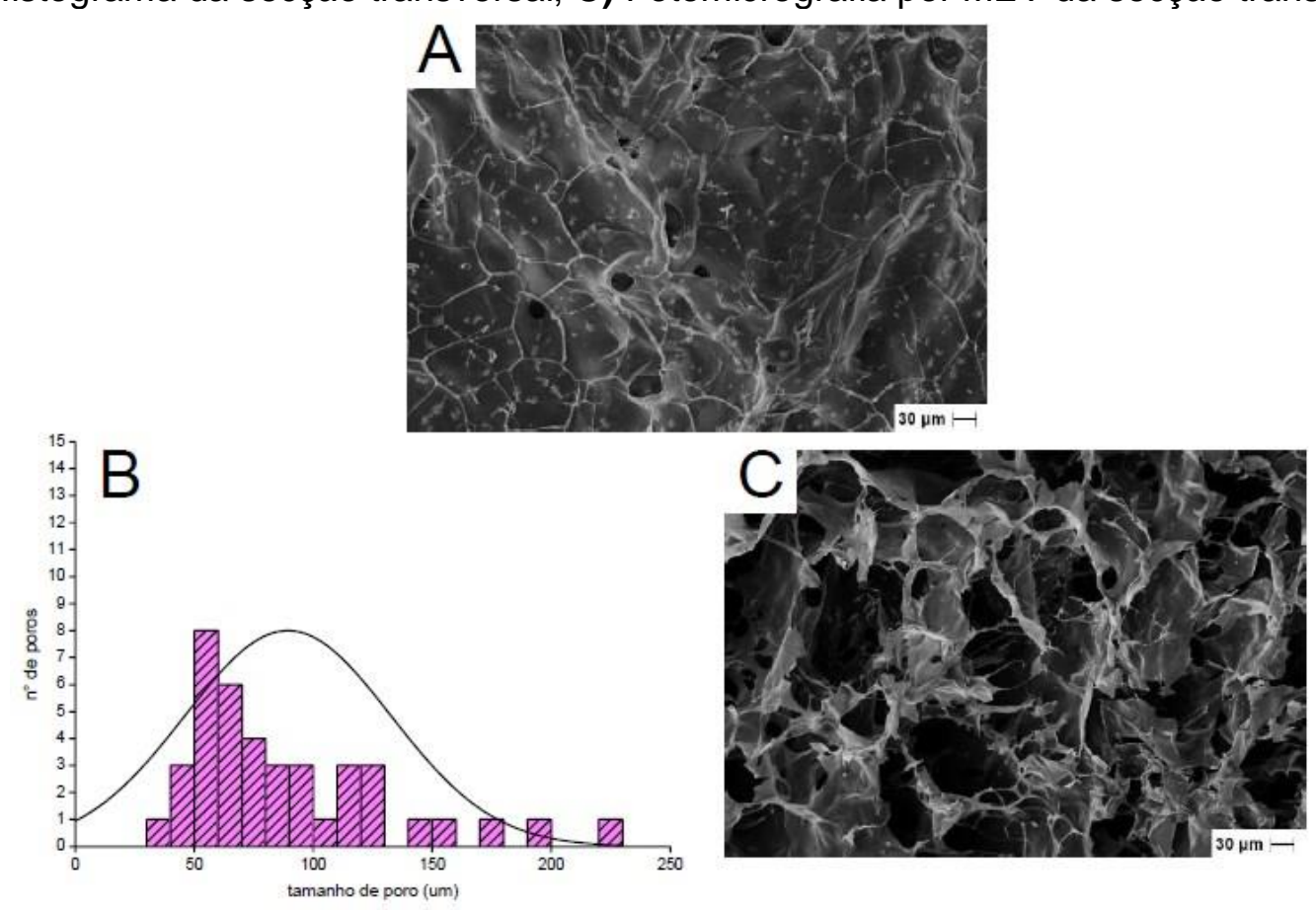

Fonte: Autoria própria 
O tamanho de poros ideal para o crescimento ósseo não é um consenso na literatura já que diferentes tamanhos de poros podem atuar de maneiras distintas na ossificação. O tamanho de poro desejável para crescimento de células ósseas é de 200 a $500 \mu \mathrm{m}$ para Mozafari et al. (2010), enquanto que Azami et al. (2013) colocam essa faixa de 150 a $350 \mu \mathrm{m}$. Oryan et al. (2014) afirmam que matrizes com poros entre 200 e $350 \mu \mathrm{m}$ são ideias para crescimento ósseo e osteocondução, além de enfatizarem que a distribuição, volume do poro e interconectividade são fatores igualmente importantes. Mais recentemente, Zhao et al. (2019) pontaram que o tamanho ideal para um scaffold de reconstrução óssea é entre 300 e $900 \mu \mathrm{m}$.

Alguns autores também apontam que poros menores que $100 \mu \mathrm{m}$ podem apresentar vantagens no crescimento ósseo, como Mauffrey et al. (2011), que além de afirmarem que o tamanho ideal para crescimento ósseo é de 150 a $500 \mu \mathrm{m}$, também afirmam que poros menores que $5 \mu \mathrm{m}$ ajudam nas propriedades bioabsorvíveis do material. Billstrom et al. (2013) indicam que biomateriais com poros entre 0,5 e $10 \mu \mathrm{m}$ promovem o crescimento de células osteogênicas, incentivando a formação óssea.

Yannas et al. (1992) concluíram que com poros muito pequenos, a migração celular para o interior da matriz é limitada, o que ocasiona na formação de uma capsula celular ao redor do scaffold, entretanto, poros muito grandes reduzem a área superficial, limitando a adesão celular. Concordante com essa pesquisa, Karageorgiou et al. (2005) apontam então que, poros com aproximadamente $100 \mu \mathrm{m}$ são ideais para migração celular e poros maiores que $300 \mu \mathrm{m}$ são mais adequados para formação óssea. Murphy et al. (2010) complementam afirmando que poros maiores que $300 \mu \mathrm{m}$ levam a osteogênese direta, e menores que $300 \mu \mathrm{m}$, induzem a ossificação endocondral. Não obstante, que para ossificação endocondral acontecer, são necessários pequenos pedaços de cartilagens para servirem de "molde" para ossificação, com isso, Velasco et al. (2015) apontaram que que poros com aproximadamente $100 \mu \mathrm{m}$ ajudam na condrogenese, enquanto poros de aproximadamente $350 \mu \mathrm{m}$ promovem a osteogênese.

Outros autores que enfatizam a importância de pequenos poros na matriz. Zhang et al. (2018) apontam que poros pequenos ajudam na fixação celular e ainda podem induzir uma força capilar que auxilia na retenção de fluidos fisiológicos e conduz células da periferia do scaffold para o interior do mesmo. 
Levando em consideração todos esses autores, é possível apontar que as matrizes $\mathrm{CP}, \mathrm{CR}$, CJ e CnHAP podem ser promissoras à osteogênese já que apresentam poros menores que $100 \mu \mathrm{m}$, que ajudam na adesão celular e intumescimento da matriz, e poros maiores que $100 \mu \mathrm{m}$ que promovem a osteogênese direta. As matrizes C, CnHAR e CnHAJ poderiam ser descartadas pela ausência de poros superficiais e a matriz CnHA por não apresentar poro maior que $50 \mu \mathrm{m}$, entretanto, exceto pela matriz $\mathrm{CnHA}$, todas as matrizes apresentam tamanho de poro interno adequado. Além disso, o colágeno e a hidroxiapatita são biomateriais que apresentam bioabsortividade e biodegradabilidade, e em um momento pós implante, a absorção desses materiais poderia modificar o tamanho de poro, tornando o material adequado a osteogênese (Alt et al., 2016; Pinto et al., 2017).

\subsection{Ensaio de porosidade}

A porosidade, assim como o tamanho de poros e sua interconectividade, é um fator importante a ser considerado da preparação de um biomaterial para reconstrução de tecido ósseo.

A porosidade das matrizes é apresentada na Tabela 7, na qual é possível se observar matrizes com valores em torno de 90\%, com exceção de CnHAR e CnHAJ, que apresentam estatisticamente valores menores de porosidade.

Tabela 7: Porosidade das matrizes

\begin{tabular}{cc}
\hline Matriz & Porosidade (\%) \\
\hline C & $92,01 \pm 3,87^{\mathrm{a}}$ \\
CP & $89,03 \pm 1,78^{\mathrm{a}}$ \\
CR & $92,98 \pm 2,55^{\mathrm{a}}$ \\
CJ & $96,23 \pm 1,95^{\mathrm{a}}$ \\
CnHA & $90,77 \pm 3,39^{\mathrm{a}}$ \\
CnHAP & $90,55 \pm 1,67^{\mathrm{a}}$ \\
CnHAR & $64,71 \pm 7,11^{\mathrm{b}}$ \\
CnHAJ & $73,86 \pm 4,10^{\mathrm{b}}$ \\
\hline
\end{tabular}

$\mathrm{Na}$ tabela, letras iguais significam valores estatisticamente iguais $(p<0,05)$.

Bartolo et al. (2011) afirmam que porosidade igual ou superior a 90\% aumenta a área superficial e permite alta eficiência na migração e proliferação celular, enquanto Fook et al. (2010) aponta que porosidades superiores a 70\% são essenciais 
para biomateriais substitutos ósseos. Uma faixa de porosidade mais abrangente é dada por Zhao et al. (2019), que dizem que a porosidade ideal para um scaffold para crescimento ósseo está entre 60 e 95\%.

É observado pelas matrizes sem nHA que a adição de extrato não influencia na porosidade da matriz, assim como que as matrizes $\mathrm{CP}, \mathrm{CR}$ e CJ não apresentam diferença significante entre suas porosidades. A adição de nHA também não influencia na porosidade da matriz, como observado na matriz $\mathrm{CnHA}$ e $\mathrm{C}$.

Com a redução na quantidade de colágeno nas matrizes, esperava-se um decaimento na porosidade, como observado nas matrizes CnHAR e CnHAJ, que apresentam respectivamente 64,71 \pm 7,11 e 73,86 \pm 4,10\%. Entretanto tal diferença não é observada na matriz CnHAP, que apresenta a mesma porosidade das demais matrizes. Isso pode ser devido ao fato do flavonoide predominante no extrato de semente de uva ser a proantocianidina, (Moreno et al., 2003; Nunes et al., 2016; Zhang et al., 2017) que se apresenta na forma de oligômero, e por isso, pode reticular o colágeno sem aproximar muito as cadeias do biopolímero. No caso dos extratos de casca de romã e jabuticaba, os flavonoides mais abundantes são catequinas (flavanóis) e antocianinas (Lajnef et al., 2018; Marques et al., 2019) que se apresentam na forma de monômeros. Esses monômeros também reticulam o colágeno, entretanto podem ocasionar um efeito maior de aproximação de cadeias, reduzindo a porosidade das matrizes (Epasinghe et al., 2017; Lucarini et al., 2019).

\subsection{Cinética de absorção em PBS}

A habilidade de uma matriz em reter água e eletrólitos é uma importante propriedade para avaliar sua eficácia como um possível biomaterial de reconstrução óssea, já que a matriz deve possibilitar a difusão fluidos e células para seu interior.

A absorção de tampão fosfato salino pelas matrizes de colágeno ocorre devido a várias interações eletrostáticas. Quando as primeiras moléculas de água entram na matriz, se ligam aos grupos hidrofílicos e polares presentes na estrutura, hidratando-a. As interações adesivas entre os diversos resíduos de aminoácidos polares presentes no colágeno e o PBS, são mais fortes do que as forças coesivas do próprio tampão. Isso faz com que o tampão seja absorvido por toda a matriz, ocasionando seu intumescimento.

O colágeno é uma proteína que apresenta característica hidrofílica devido ao grande conteúdo de resíduos de aminoácidos hidroxilados, como no caso da 
hidroxiprolina. Além disso, apresenta também grande quantidade do resíduo de aminoácido prolina, que é um desestabilizante da a-hélice devido ao anel pirrolidina, que por sua vez, desocupa sítios de ligações de hidrogênio na estrutura secundaria do biopolímero, contribuindo com a característica hidrofílica do colágeno (Arvanitoyannis, 1998; Wolf, 2007).

Os flavonoides presentes nos três extratos apresentam a capacidade de reticular o colágeno, e com isso, esperava-se que as matrizes intumescessem menos já que a permeabilidade do solvente é dificultada devido ao maior número de sobreposições de cadeias poliméricas (Walters et al., 2014). Porém, as hidroxilas dos extratos tornam a matriz com característica hidrofílica, assim como a hidroxiapatita que apresenta duas hidroxilas por célula unitária (Guastaldi, 2010).

Assim, a capacidade de absorção de fluidos pelas matrizes será decorrente da contribuição hidrofílica do colágeno, da nanohidroxiapatita e dos três extratos, em contrapartida ao quanto as matrizes foram reticuladas.

Todas as matrizes em torno de 24 horas já atingem carga máxima de intumescimento e seus pontos de 120 e 1440 minutos são apresentados na Tabela 8. Observa-se que em 1440 min, a matriz CnHA apresentou a menor absorção de PBS, não tendo diferença estatística da mostrada para a matriz $C$, indicando que apenas a adição de nanohidroxiapatita na concentração testada não induz a um aumento de absorção. A Figura 33 mostra a absorção das matrizes C e CnHA em diferentes tempos, não apresentando absorção superior a 1450\%.

Tabela 8: Porcentagem de absorção de tampão fosfato salino

\begin{tabular}{ccc}
\hline \multirow{2}{*}{ Matriz } & \multicolumn{2}{c}{ \% de absorção de PBS } \\
\cline { 2 - 3 } & $\mathbf{1 2 0} \mathbf{~}$ in & $\mathbf{1 4 4 0 ~}$ min \\
\hline C & $977,43 \pm 109,34^{\mathrm{d}, \mathrm{e}, \mathrm{f}}$ & $1337,25 \pm 83,47^{\mathrm{c}, \mathrm{d}}$ \\
CP & $1365,71 \pm 108,25^{\mathrm{b}}$ & $1720,19 \pm 105,58^{\mathrm{b}, \mathrm{c}}$ \\
CR & $1173,91 \pm 187,25^{\mathrm{b}, \mathrm{d}, \mathrm{e}}$ & $1620,96 \pm 131,27^{\mathrm{b}, \mathrm{c}}$ \\
CJ & $2349,66 \pm 283,57^{\mathrm{a}}$ & $3057,11 \pm 267,61^{\mathrm{a}}$ \\
CnHA & $652,07 \pm 146,67^{\mathrm{f}}$ & $990,82 \pm 210,59^{\mathrm{d}}$ \\
CnHAP & $2554,65 \pm 220,02^{\mathrm{a}}$ & $2769,71 \pm 214,32^{\mathrm{a}}$ \\
CnHAR & $883,23 \pm 138,18^{\mathrm{c}, \mathrm{e}, \mathrm{f}}$ & $1103,94 \pm 158,49^{\mathrm{d}}$ \\
CnHAJ & $1278,89 \pm 129,90^{\mathrm{b}, \mathrm{c}, \mathrm{d}}$ & $2033,51 \pm 342,21^{\mathrm{b}}$ \\
\hline
\end{tabular}

Em uma mesma coluna, letras iguais significam valores estatisticamente iguais $(p<0,05)$ 
Figura 33: Porcentagem de absorção das matrizes $\mathrm{C}(\square)$ e $\mathrm{CnHA}(\mathbf{\square})$

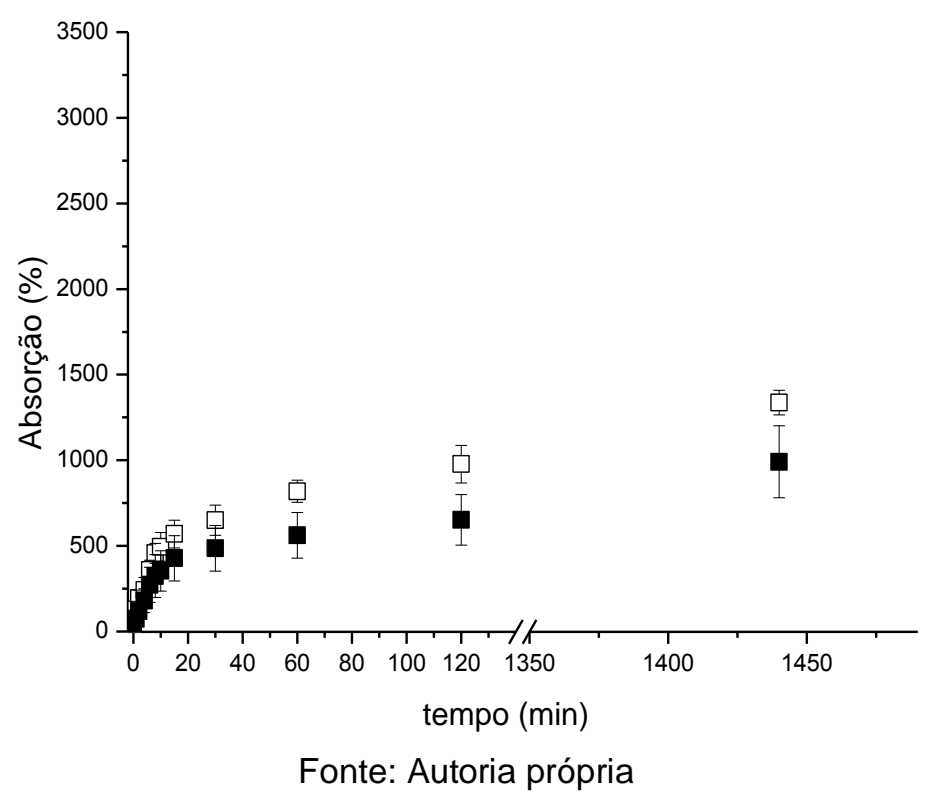

Kozlowska et al. (2017) testaram a absorção em PBS de matrizes de colágeno e colágeno com hidroxiapatita com diferentes proporções. Eles observaram que com o aumento da quantidade de hidroxiapatita na matriz, menor é a absorção de PBS. Entretanto, a quantidade de hidroxiapatita na matriz $\mathrm{CnHA}$ deste trabalho é inferior a quantidade testada por Kozlowska et al. (2017), indicando que em maiores concentrações de nHA, talvez seja observada diferença estatística na absorção das matrizes $\mathrm{C}$ e $\mathrm{CnHA}$.

Arahira e Todo (2016) realizaram ensaios de absorção em PBS de matrizes de colágeno e colágeno com fosfato tricálcico ( $\beta$-TCP) e também concluíram que adição do fosfato de cálcio reduz a porcentagem de absorção. Entretanto, a matriz de colágeno desses autores absorveu um máximo de $400 \%$, diferente da matriz de colágeno desse trabalho que absorveu mais que o dobro de PBS.

Ao se comparar a absorção das matrizes C, CP e CR, pode-se afirmar que a adição de extrato de semente de uva ou de casca de romã não altera a absorção de PBS, apresentando porcentagens de absorção estatisticamente iguais no período de 24h. Entretanto, a adição do extrato de jabuticaba aumenta significativamente a absorção de tampão, como pode ser observado na Figura 33.

Nem sempre a reticulação de matrizes de colágeno altera a porcentagem de absorção de PBS, como é mostrado por Sionkowska e Grabska (2017). Os autores testaram a absorção de matrizes de colágeno e colágeno reticulado com amida de dialdeido e obtiveram valores de $1055 \%$ e $1084 \%$ respectivamente. 
Figura 34: Porcentagem de absorção das matrizes $\mathrm{C}(\square)$; CP $(\bigcirc)$, CR $(\Delta)$; CJ $(\diamond)$

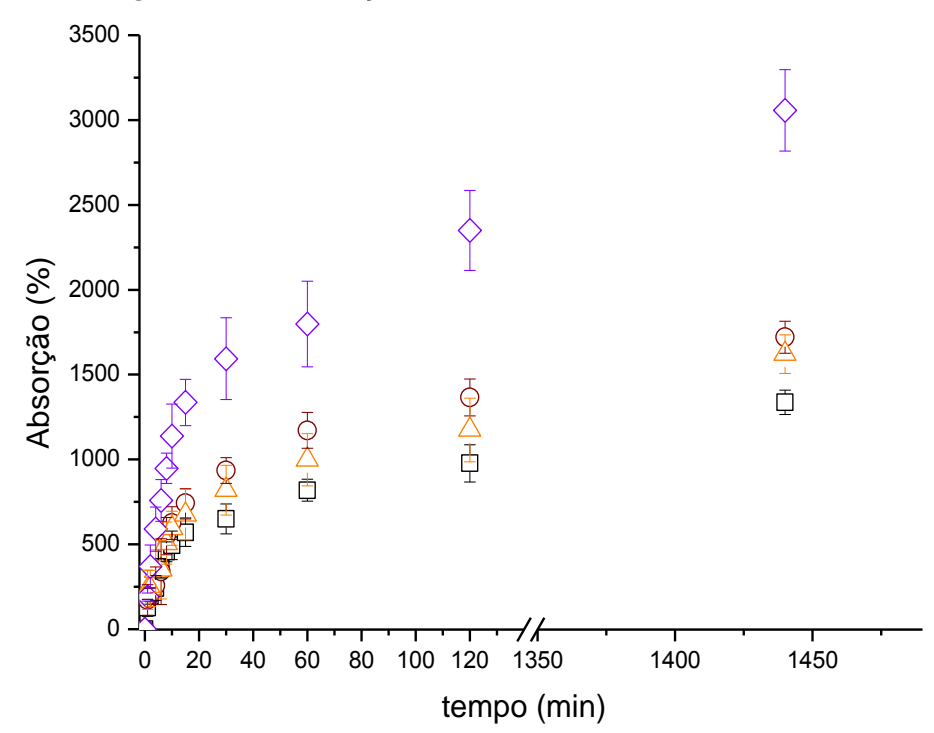

Fonte: Autoria própria

Ao se adicionar nanohidroxiapatita a matriz de extrato de semente de uva, há um aumento significativo na absorção de PBS (Figura 35), entretanto ao se adicionar a nHA às matrizes com extrato de romã e jabuticaba, o efeito observado é o oposto, reduzindo a porcentagem de absorção das matrizes (Figuras 36 e 37).

Figura 35: Porcentagem de absorção das matrizes CP (O) e CnHAP (•)

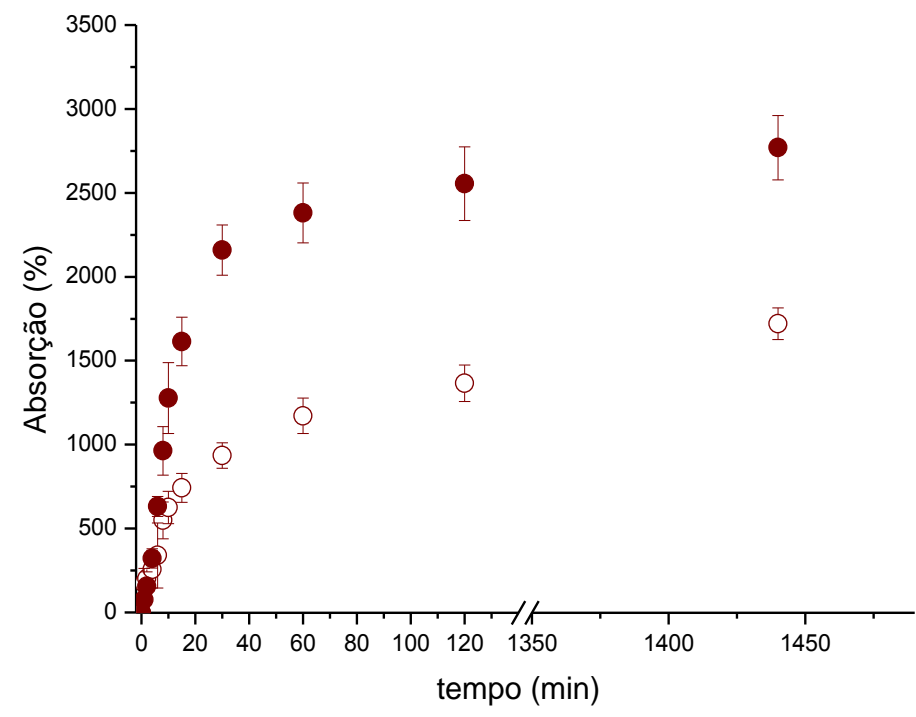

Fonte: Autoria própria 
Figura 36: Porcentagem de absorção das matrizes $\mathrm{CR}(\Delta)$ e $\mathrm{CnHAR}(\Delta)$

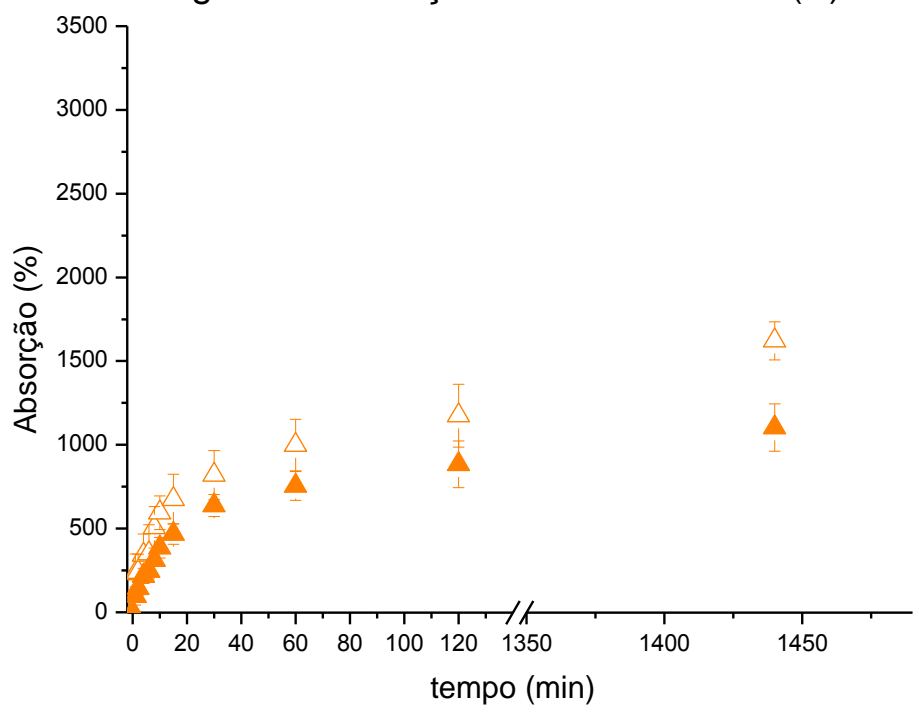

Fonte: Autoria própria

Figura 37: Porcentagem de absorção das matrizes CJ $(\diamond)$ e $\mathrm{CnHAJ}(\diamond)$

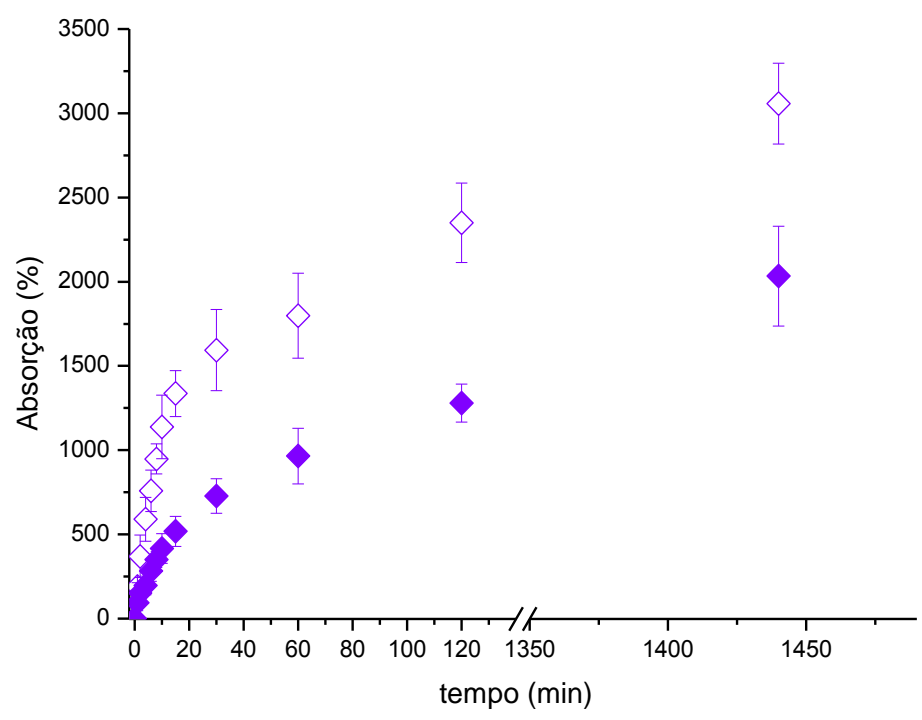

Fonte: Autoria própria

A Figura 38 mostra a comparação da absorção das matrizes contendo hidroxiapatita. É possível observar que CnHA e CnHAR apresentam a mesma porcentagem de absorção, semelhante ao ocorrido com as matrizes $\mathrm{C}$ e CR.

Em 24h, a matriz CnHAP apresenta a maior absorção dentre as matrizes com $\mathrm{nHA}$, sendo estatisticamente igual a absorção da matriz CJ que absorveu $3057,11 \pm 267,61 \%$. 
Figura 38: Porcentagem de absorção das matrizes $\mathrm{CnHA}(\bullet)$; $\mathrm{CnHAP}(\bullet)$;

CnHAR $(\Delta) ; \operatorname{CnHAJ}(\diamond)$.

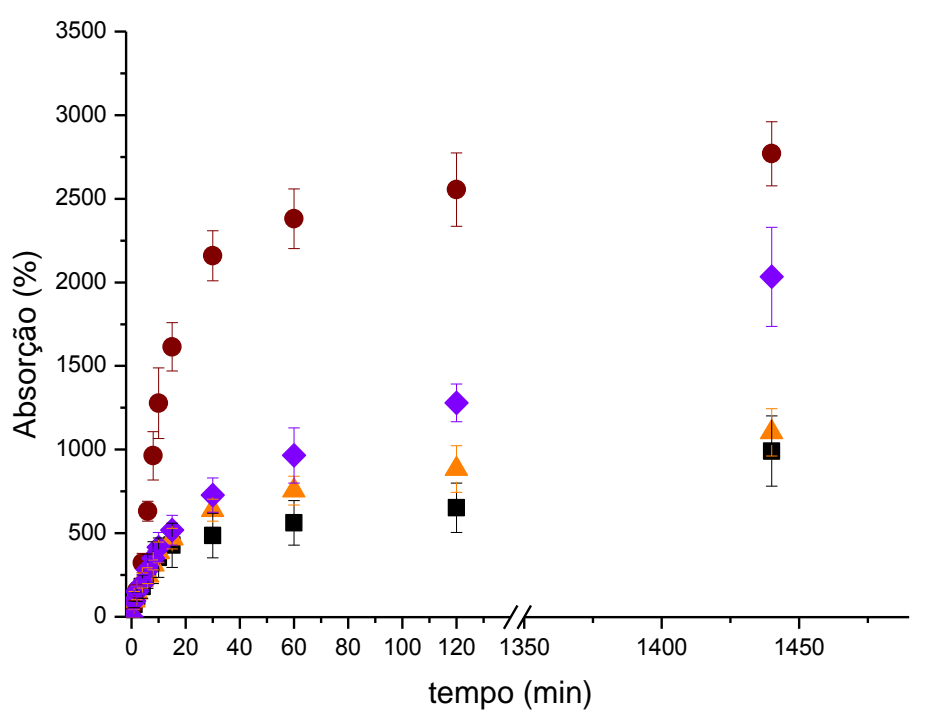

Fonte: Autoria própria

\subsection{Degradação via colagenase}

\subsubsection{Análise da degradação das matrizes}

A característica de se biodegradar é fundamental para biomateriais de reconstrução óssea. Idealmente o biomaterial deve se degradar em mesma proporção que promove a osteocondução, sem gerar resíduos prejudiciais à osteogênese (Schopper et al., 2005; Soares, 2015; Russmuller et al., 2015). O ensaio em colagenase pode ser um indicativo da biodegradabilidade do biomaterial pós-implante.

Por ser uma proteína fibrosa com baixa solubilidade em meios aquosos, 0 colágeno é clivado apenas por enzimas colagenases. Essas enzimas tem a capacidade de clivar a hélice tripla através do rompimento da ligação peptídica entre glicina e leucina (ou isoleucina), Gly ${ }^{775}$ Leu $^{776}$ (ou $11 e^{776}$ ), formando fragmentos de cadeias peptídicas de comprimento de 1/4 e 3/4 (Tam et al., 2004; Gioia et al., 2002).

A degradação do colágeno in vitro pela colagenase ocorre em três etapas distintas, sendo elas a difusão, na qual a colagenase em tampão tris- $\mathrm{HCl}$ se difunde pelo substrato, que no caso é o próprio colágeno, a absorção, na qual a enzima é adsorvida sobre a superfície do colágeno e a degradação, na qual a molécula é quebrada em fragmentos menores denominados "peptídeos de colágeno" (Metzmacher, 2005; Oliveira et al., 2017). 
A Tabela 9 mostra a porcentagem de degradação das matrizes nos tempos de 2 e 6 horas.

Tabela 9: Porcentagem de degradação das matrizes em diferentes tempos

\begin{tabular}{ccc}
\multirow{2}{*}{ Matriz } & \multicolumn{2}{c}{ Degradação (\%) } \\
\cline { 2 - 3 } & $7,53 \pm 1,49^{\mathrm{c}}$ & $\mathbf{6 h}$ \\
\hline C & $-1,01 \pm 1,76^{\mathrm{d}}$ & $27,63 \pm 4,11^{\mathrm{a}}$ \\
CP & $5,37 \pm 2,10^{\mathrm{c}}$ & $-2,81 \pm 2,95^{\mathrm{e}}$ \\
CR & $4,01 \pm 2,28^{\mathrm{c}}$ & $7,66 \pm 1,26^{\mathrm{c}, \mathrm{d}}$ \\
CJ & $22,70 \pm 3,00^{\mathrm{a}}$ & $3,98 \pm 0,62^{\mathrm{d}}$ \\
CnHA & $4,33 \pm 1,37^{\mathrm{c}}$ & $29,68 \pm 2,65^{\mathrm{a}}$ \\
CnHAP & $16,45 \pm 0,15^{\mathrm{b}}$ & $16,31 \pm 4,22^{\mathrm{b}}$ \\
CnHAR & $13,79 \pm 0,05^{\mathrm{b}}$ & $14,33 \pm 2,06^{\mathrm{b},}$ \\
CnHAJ & $12,18 \pm 2,14^{\mathrm{b}, \mathrm{c}}$ \\
\hline
\end{tabular}

Em uma mesma coluna, letras iguais significam valores estatisticamente iguais $(p<0,05)$

As matrizes que apresentaram diferença na porcentagem de degradação comparando-se os dois tempos, foram as matrizes $\mathrm{C}, \mathrm{CnHA}, \mathrm{CnHAP}$, sendo que as três apresentaram maior degradação no tempo de 6h. Os valores negativos para a porcentagem de degradação observados na matriz CP podem ser resultantes de pequenas variações de pesagens no experimento, já que não houve perda de massa significativa da matriz, qualquer pequena diferença ocasiona um "falso" valor de degradação.

No período de 6 horas, observa-se que a adição de extrato reduz a porcentagem de degradação do colágeno, sendo que a menor porcentagem foi da matriz CP, que não degradou. Isso é um indicativo que os extratos atuam como agente de reticulação do colágeno e que o extrato de semente de uva é o que apresenta maior capacidade reticulante, o que condiz com o fato da matriz CP apresentar maior temperatura de desnaturação. Um resultado concordante a este foi apresentado por Green et al. (2010), que utilizaram as proantocianidinas do extrato de semente de uva em adesivos de colágeno usados em periodontia. Eles concluíram que o extrato provoca a reticulação do biopolímero e isso reduz sua biodegradação.

Ao se comparar as matrizes C e CnHA, observa-se que a adição de nanohidroxiapatita aumenta a porcentagem de degradação do colágeno, indicando que a biocerâmica desestabiliza a matriz. Entretanto, os valores obtidos após 6h não 
foram estatisticamente maiores que os observados após $2 \mathrm{~h}$ indicando que essa desestabilização é parcial.

Ao comparar as matrizes CP com CnHAP, CR com CnHAR e CJ com CnHAJ, em ambos os tempos, observa-se que as matrizes com hidroxiapatita apresentam uma degradação ligeiramente maior, indicando a desestabilização ocasionada pela biocerâmica, principalmente em relação a CnHAP.

Íons de carga positiva como o $\mathrm{Ca}^{2+}$ presente na hidroxiapatita tem afinidade com as fibras aniônicas do colágeno, o que causa uma redução nas interações fibrafibra do colágeno, ocasionando uma desestabilização física na matriz, e assim, podendo aumentar a degradação (Tampieri, 2014).

\subsubsection{MEV das matrizes degradadas}

A Figura 39 mostra a morfologia superficial das matrizes degradadas no período de 6h. A Tabela 10 compara o tamanho de poro, junto ao coeficiente de variação (Cv) das matrizes não degradadas (igual ao apresentado na Tabela 5) com o tamanho de poro e Cv das matrizes degradadas em 6h. O Apêndice A mostra as fotomicrografias da superfície das matrizes não degradadas e das matrizes degradadas por $6 \mathrm{~h}(\mathrm{~d} 6 \mathrm{~h})$.

Tabela 10: Comparação entre os tamanhos de poro da superfície das matrizes não degradadas e degradadas após $6 \mathrm{~h}$

\begin{tabular}{ccccc}
\hline \multirow{2}{*}{ Matriz } & \multicolumn{4}{c}{ Tamanho do poro da superfície das matrizes } \\
\cline { 2 - 5 } & \multicolumn{2}{c}{ não degradadas } & \multicolumn{2}{c}{ degradadas $(6 \mathrm{~h})$} \\
\cline { 2 - 5 } & Média \pm dp $(\boldsymbol{\mu} \mathrm{m})$ & $\mathbf{C v}(\%)$ & Média \pm dp $(\boldsymbol{\mu m})$ & $\mathbf{C v}(\%)$ \\
\hline C & - & - & $64,6 \pm 31,2$ & 48,2 \\
CP & $56,3 \pm 23,9^{\mathrm{a}}$ & 42,4 & $157,5 \pm 87,4^{\mathrm{b}}$ & 55,5 \\
CR & $126,1 \pm 118,6^{\mathrm{a}}$ & 94,0 & $129,1 \pm 82,2^{\mathrm{a}}$ & 63,6 \\
CJ & $72,8 \pm 47,1^{\mathrm{a}}$ & 64,7 & $130,1 \pm 65,7^{\mathrm{b}}$ & 50,5 \\
CnHA & $28,1 \pm 7,5^{\mathrm{a}}$ & 26,6 & $110,7 \pm 18,5^{\mathrm{b}}$ & 16,7 \\
CnHAP & $47,1 \pm 24,2^{\mathrm{a}}$ & 51,4 & $130,3 \pm 71,0^{\mathrm{b}}$ & 54,5 \\
CnHAR & - & - & - & - \\
CnHAJ & - & - & $52,8 \pm 14,1$ & 14,1 \\
\hline
\end{tabular}

Na mesma linha, letras iguais significam números estatisticamente iguais 
Figura 39: Fotomicrografia por MEV da superficie das matrizes degradadas por $6 \mathrm{~h}$ : A) C; B) CnHA; C) CP; D) CnHAP; E) CR; F) CnHAR; G) CJ; H) CnHAJ
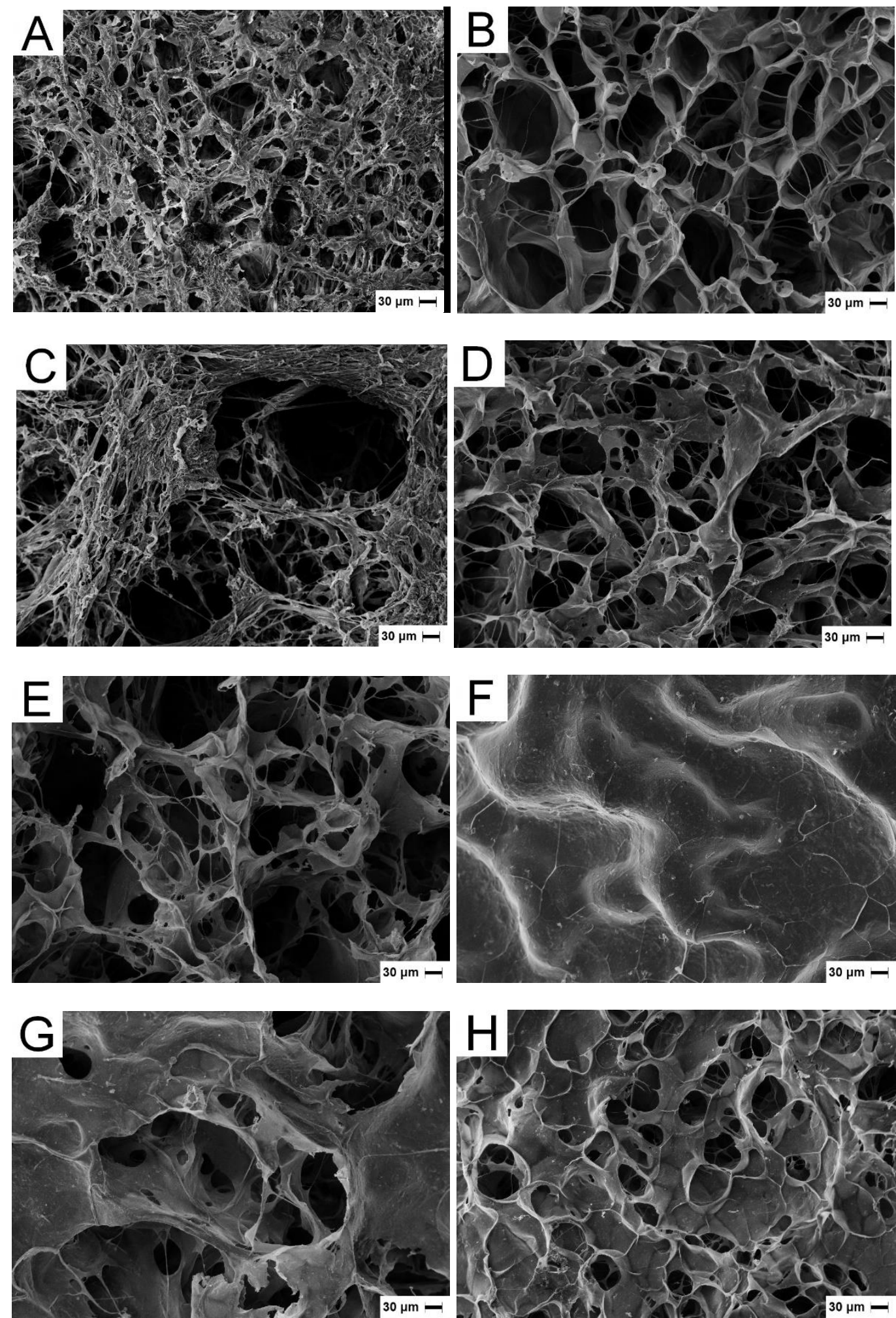

Fonte: Autoria própria 
Comparando-se as Figuras 38A e 24A, observa-se que a matriz $\mathrm{C}$ que antes apresentava uma superfície rugosa sem a presença de poros, agora apresenta uma superfície com poros de 64,6 \pm 31,2 $\mu \mathrm{m}$. A matriz CnHAJ que, por apresentar poucos poros em sua superfície foi considerada como não porosa, agora apresenta poros de 52,8 \pm 14,1 $\mu \mathrm{m}$ e a matriz CnHAR continuou apresentando uma superfície rugosa, com ausência de poros.

Os poros da matriz CR, não apresentaram diferença estatística em seus tamanhos após a degradação, entretanto, para as matrizes CP, CJ, CnHA e CnHAP, é observado um aumento no tamanho dos poros.

Com isso, pode-se concluir que com exceção das matrizes com romã (CR e CnHAR), a degradação via colagenase induz o aparecimento de poros na superfície das matrizes e seu aumento.

\subsection{Ensaio de atividade antimicrobiana}

\subsubsection{Atividade antimicrobiana dos extratos}

As hidroxilas presentes nos flavonoides os conferem atividade antimicrobiana, agindo em nível de membrana celular em bactérias (Reygaert, 2014) (Gorniak et al., 2019), entretanto, foi observado que os extratos apresentaram atividade antimicrobiana apenas contra a bactéria Gram-positiva Staphylococcus aureus, sendo ineficazes contra as bactérias Gram-negativas Pseudomonas aeruginosa e Salmonella enterica Enteritidis nas concentrações testadas.

A quantidade e tipos de flavonoides presentes nos frutos podem variar em decorrência das condições ambientais na qual os frutos foram produzidos (clima, disponibilidade de água, luz, etc) (Gomes et al., 2018). Outro fator a ser considerado é a forma da extração em que as cascas e sementes são submetidas para se produzir os extratos. Por isso, a atividade antimicrobiana de extratos naturais contendo flavonoides não é um consenso na literatura, entretanto é observado que os flavonoides tendem a apresentar maior atividade antimicrobiana contra bactérias Gram-positivas comparado às Gram-negativas (Silva et al., 2014; Oliveira et al. 2013). A Figura 40 mostra a placa de microdiluição utilizada no ensaio da atividade antimicrobiana da bactéria positiva Staphylococcus aureus. 
Figura 40: Fotografia digital da determinação da CIM da linhagem de S. aureus, sendo: J) extrato de casca de jabuticaba; R) extrato de casca de romã; $\mathbf{P}$ ) extrato semente de uva;

$\mathbf{C +}$ ) controle positivo; $\mathbf{C}$-) controle negativo
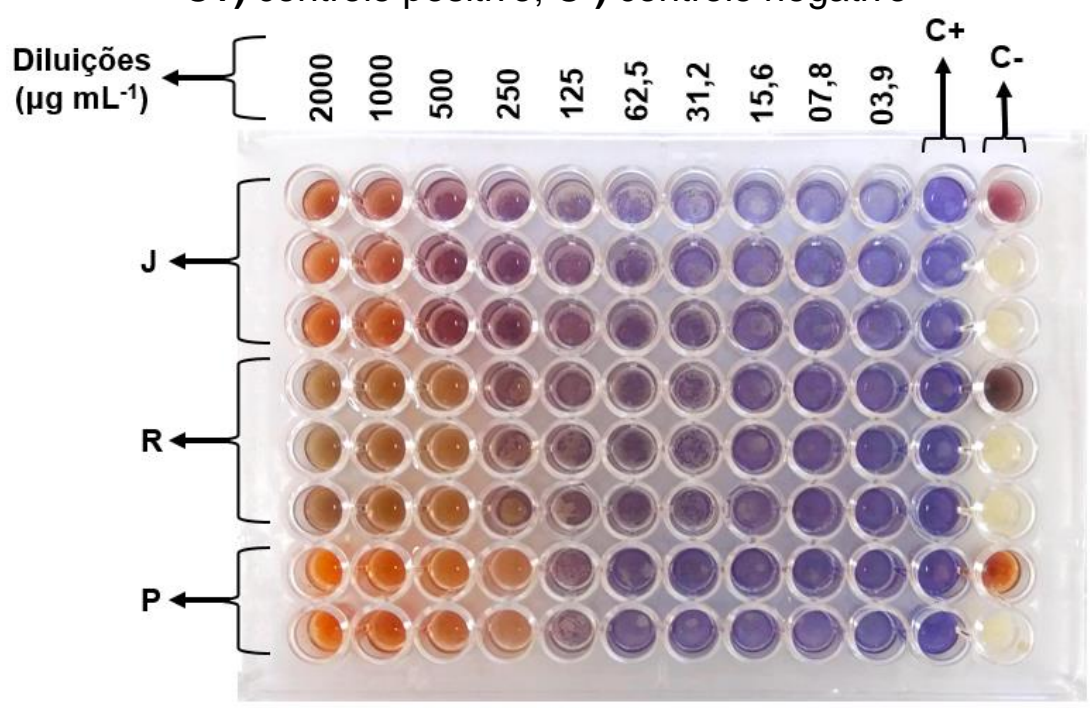

Fonte: Autoria própria

O extrato de semente de uva apresentou menor valor de CIM e CBI em relação aos outros dois extratos, sendo de $250 \mu \mathrm{g} \mathrm{mL}^{-1}, 40$ vezes menor que a CIM encontrado por Klancnik et al. (2010), de $10 \mathrm{mg} \mathrm{mL}^{-1}$.

Tabela 11: Valores de CIM e CBM dos diferentes extratos sobre $S$. aureus

\begin{tabular}{|c|c|c|}
\hline Extratos & $\operatorname{CIM}\left(\mu \mathrm{g} \mathrm{mL}^{-1}\right)$ & CBM $\left(\mu \mathrm{g} \mathrm{mL}^{-1}\right)$ \\
\hline Semente de uva & 250 & 250 \\
\hline Casca de romã & 500 & 500 \\
\hline Casca de jabuticaba & 1000 & 2000 \\
\hline
\end{tabular}

Gullon et al. (2016) avaliaram a atividade antimicrobiana do extrato de casca de romã e encontraram valores de CIM e CBM de 50 e 60 mg mL-1, respectivamente para $S$. aureus e $S$. Enteritidi, enquanto Baldin et al. (2014) avaliaram a atividade do extrato de casca de jabuticaba e obtiveram um valor de CIM de 3,13 $\mathrm{mg} \mathrm{mL}^{-1}$ para a $S$. aureus, mais de três vezes o valor encontrado neste trabalho.

Os três extratos mostraram ter melhor atividade antimicrobiana do que a encontrada na literatura para a linhagem de $S$. aureus. Na concentração testada de até $2000 \mu \mathrm{g} \mathrm{mL}^{-1}$, os extratos não apresentaram atividade contra as bactérias Gramnegativas (Pseudomonas aeruginosa e Salmonella enterica), conforme observado também por Klancnik et al. (2010) para o extrato de semente de uva. 


\subsubsection{Atividade antimicrobiana das matrizes}

As matrizes colocadas em ágar Müeller Hinton para controle negativo mostraram que a esterilização por radiação gama na dose de 15 kGy foi efetiva. Também foi observado um halo de inibição do antibiótico (Figura 41) de 23,5 \pm 0,7 mm, estando de acordo com a norma EUCAST (2019).

Esperava-se que a incubação a $37^{\circ} \mathrm{C}$ após $2 \mathrm{~h}$ em geladeira reduzisse 0 metabolismo bacteriano, possibilitando que os extratos nas matrizes permeassem pelo meio antes do crescimento das bactérias, ocasionando um maior halo de inibição, quando comparado à incubação imediata a $37^{\circ} \mathrm{C}$ (Michalska-Sionkowska et al., 2017). Entretanto, não foi observada diferença entre essas duas condições de incubação e a triplicata foi feita somente com a condição de incubação imediata em estufa bacteriológica.

Figura 41: Fotografia do A) halo do antibiotico; B) controle positivo

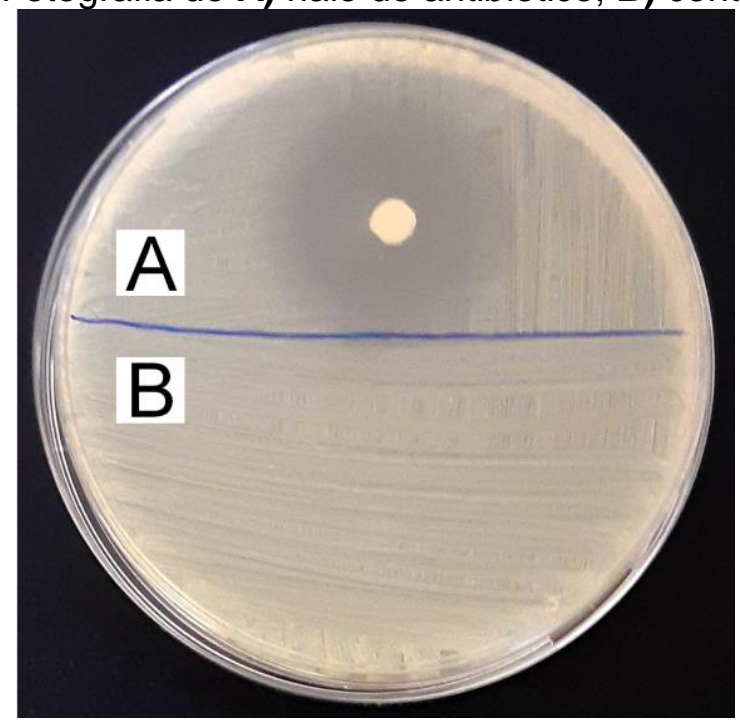

Fonte: Autoria própria

Com o ensaio de disco difusão, foi observado que apenas a matriz com colágeno e extrato de casca de romã (CR) apresentou difusividade no meio Müeller Hinton, apresentando a formação de halo de inibição de 18,6 $\pm 2,3 \mathrm{~mm}$, conforme mostra a Figura 42. 
Figura 42: Fotografia do ensaio de disco difusão das matrizes $\mathbf{A}) \mathrm{C}$; $\mathbf{B}) \mathrm{CP}$; $\mathbf{C}) \mathrm{CR}$; D) CJ; E) CnHA; F) CnHAP; G) CnHAR; H) CnHAJ

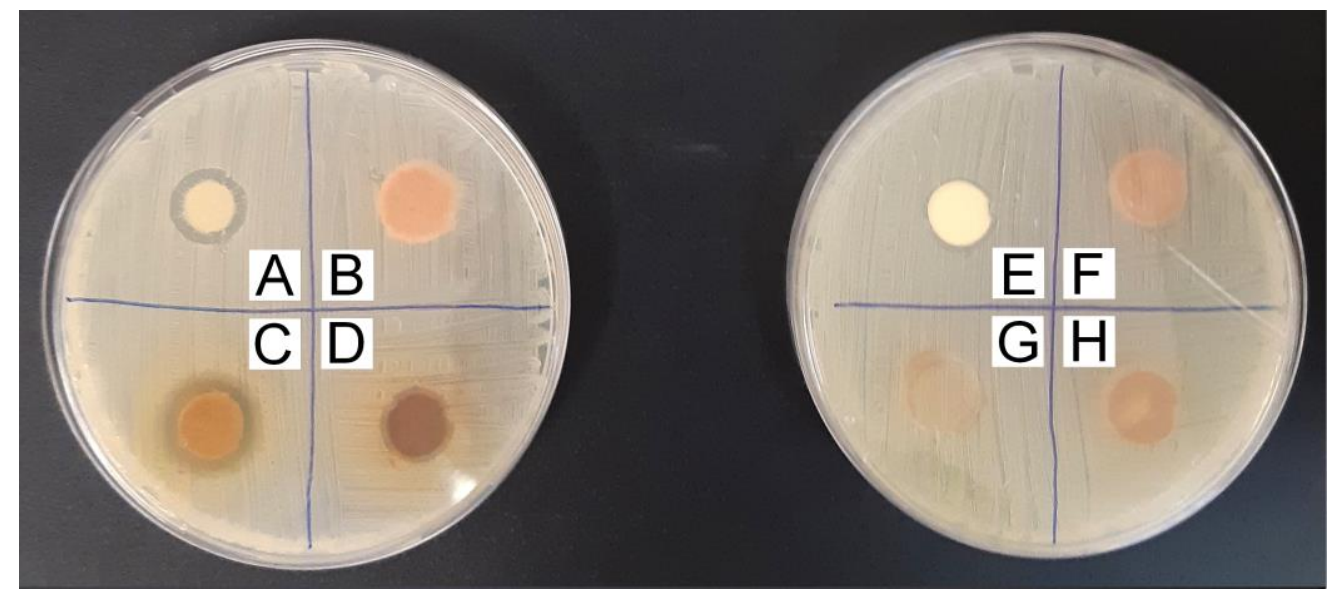

Fonte: Autoria própria

Como já descrito pela literatura, colágeno e hidroxiapatita não apresentam atividade antimicrobiana, então era esperado que as matrizes C e CnHA não formassem halo. Entretanto, os extratos apresentam atividade antimicrobiana frente a linhagem S. aureus, como apresentado no tópico 5.11.1.

Já que os extratos atuam como agente reticulante do colágeno, estes estão ligados física ou quimicamente à estrutura polimérica, reduzindo sua difusibilidade no meio e reduzindo assim, sua ação antimicrobiana (He et al., 2011; Vidal et al., 2016).

Moreira et al. (2014) avaliaram a atividade antimicrobiana do extrato hidroetanólico de casca de romã em diferentes concentrações, utilizando a técnica de difusão em disco. Para a maior concentração de extrato testada, $4 \mathrm{mg} \mathrm{mL}^{-1}$, obtiveram um halo de 30,3 mm frente a linhagem de $S$. aureus. O maior valor de halo encontrado por Moreira et al. (2014) pode ser atribuído ao fato de usarem o extrato na forma liquida e não associado a materiais sólidos. Quando ligado fisicamente ao colágeno, a difusão do extrato de casca de romã é reduzida.

Hanani et al. (2019) testaram a atividade antimicrobiana do extrato de casca de romã associado a gelatina de peixe. Em um filme de gelatina com $5 \%$ de extrato, obtiveram um halo de $7 \mathrm{~mm}$ para $S$. aureus. A matriz CR deste trabalho apresenta concentração de 14,3\% (massa/massa) de extrato, maior concentração que apresentado por Hanani et al. (2019), indicando que quanto maior a concentração de extrato, maior o halo formado. 


\subsection{Ensaios de citotoxicidade}

Os ensaios de citotoxicidade são usados para avaliar o comportamento dos materiais a um momento pós-implante, visto que para dar sequência em testes in vivo os materiais não devem apresentar citotoxicidade.

Para os testes de contato direto a Tabela 12 adaptada da ISO 10993-5 foi utilizada para se definir a citotoxicidade dos extratos vegetais e da nanohidroxiapatita. Para os testes de contato indireto (item 5.12.2), foram considerados como não citotóxicos, os extratos das matrizes com viabilidade celular superior a $70 \%$ e citotóxicos os que apresentarem viabilidade celular menor que $70 \%$, em relação ao controle negativo.

Tabela 12: Faixa de citotoxicidade considerada

\begin{tabular}{|cc|}
\hline Citotoxicidade & Faixa de viabilidade celular $(\%)^{*}$ \\
\hline Não-citotóxico & $>90$ \\
Citotoxicidade leve & $80-90$ \\
Citotoxicidade moderada & $50-80$ \\
Citotoxicidade severa & $<50$ \\
\hline
\end{tabular}

* porcentagem em relação ao controle negativo de toxicidade (controle de células)

Fonte: ISO 10993-5 (1999)

\subsubsection{Citotoxicidade dos extratos vegetais e da nanohidroxiapatita}

A Figura 43 mostra a placa de microdiluição de um dos ensaios de citotoxicidade, enquanto a Figura 44 mostra porcentagem de viabilidade celular dos extratos e da nanohidroxiapatita, frente a linhagem de fibroblastos de camundongos $\mathrm{NIH} / 3 \mathrm{~T} 3$.

A hidroxiapatita é muito utilizada como biomaterial para regeneração de tecido duro graças a sua biocompatibilidade, então era esperado que não apresentasse citotoxicidade (Shanthi et al., 2009; Bezerra et al., 2017; Pearson et al., 2019). Também é observado que com o aumento na concentração da nanohidroxiapatita, ocorre o aumento da viabilidade celular chegando próxima a 160\% em períodos de 24 e 48h, indicando que a nanohidroxiapatita sintetizada apresenta propriedades proliferativas e por isso, apresenta boa biocompatibilidade e pode ser de grande utilidade como biomaterial de reconstrução de tecidos. 
Figura 43: Fotografia da placa de microdiluição para o ensaio de citotoxicidade dos: P) extrato de semente de uva; $\mathbf{R}$ ) extrato de casca de romã; J) extrato de casca de jabuticaba; $\mathbf{n H A}$ ) nanohidroxiapatita; onde $\mathbf{C +}$ ) controle positivo; $\mathbf{C}$-) controle negativo;

B) branco

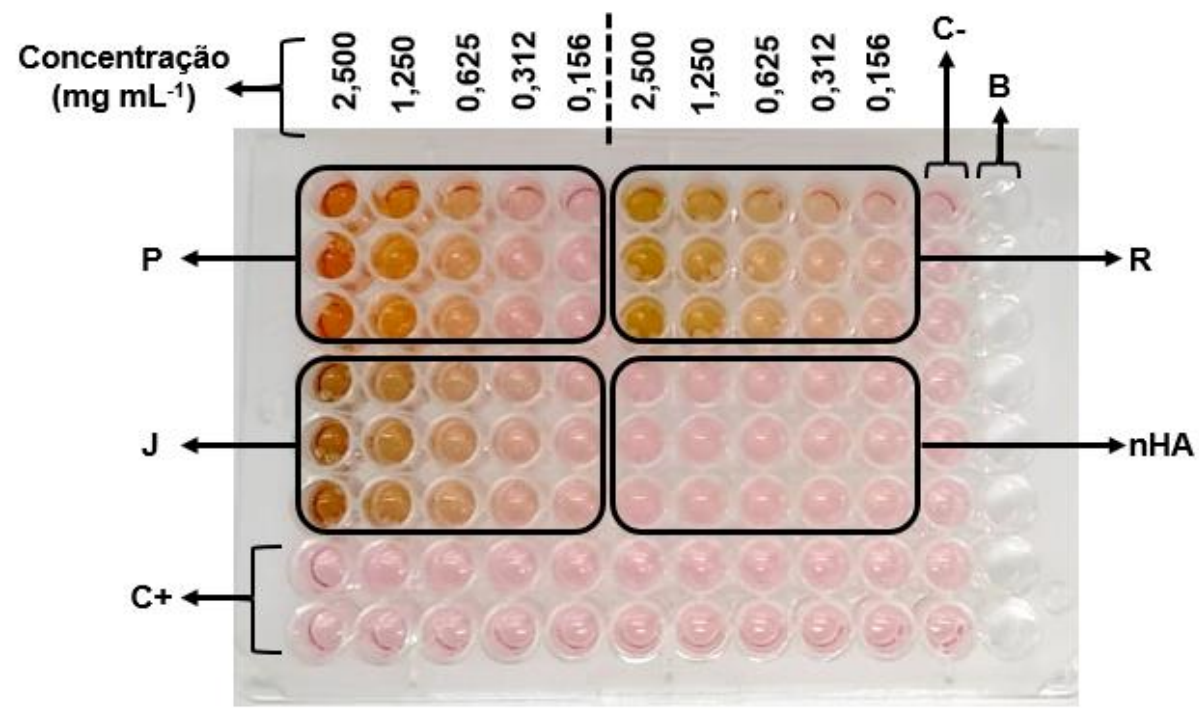

Fonte: Autoria própria

Os extratos de romã e jabuticaba apresentam propriedades proliferativas no período de $24 \mathrm{~h}$, na concentração de $0,156 \mathrm{mg} \mathrm{mL}^{-1}$, diferente do extrato de uva que apresenta citotoxicidade moderada nesse período. Em 48h, apenas o extrato de jabuticaba apresentou propriedades não-citotoxicas nessa concentração.

Com o aumente da concentração, observa-se que os extratos reduzem a viabilidade celular apresentando citotoxicidade moderada ou severa a partir da concentração de $0,312 \mathrm{mg} \mathrm{mL}^{-1}$ em ambos os períodos.

A capacidade de remoção de radicais livres dos flavonoides os confere atividade citotóxica dos extratos (Banerjee et al., 2012; Santos et al., 2017). Entretanto, a atividade citotóxica dos extratos assim como a atividade antimicrobiana é correlacionada às condições ambientais na qual os frutos foram produzidos (Gomes et al., 2018) assim como o processo de extração do extrato. Com isso, diversos pesquisadores encontram valores de citotoxicidade diferentes para extratos oriundos da mesma fruta.

Apesar disso, diversos autores continuam a pesquisar a utilização de extratos naturais na área medicinal, incorporando-os em biomateriais ou como fármacos, assim como estudam sua citotoxicidade em diferentes culturas celulares. 
Figura 44: Porcentagem de viabilidade celular em: (A) 24h e (B) 48h, para $(\nabla) \mathrm{nHA} ;(\boldsymbol{\bullet}) \mathrm{P} ;(\bullet) \mathrm{R} ;(\boldsymbol{\Delta}) \mathrm{J}$
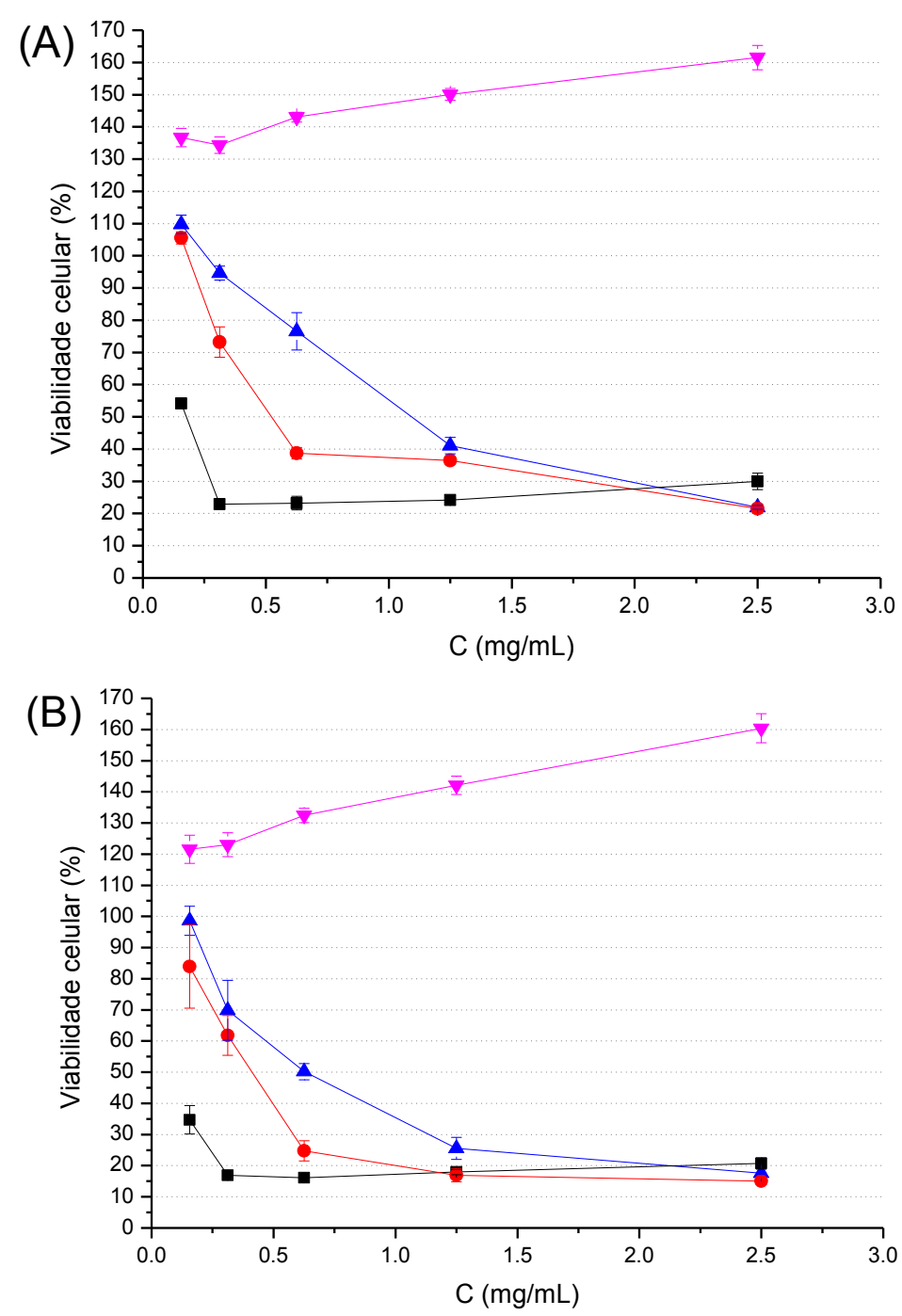

Fonte: Autoria própria

Okonogi et al. (2007) avaliaram a citotoxicidade do extrato de casca de romã, extraído em solução hidroetanólica $95 \%$ por 3 dias. Com isso, relataram que até a concentração de $0,1 \mathrm{mg} \mathrm{mL}^{-1} \mathrm{o}$ extrato aumenta a viabilidade celular das células Caco-2 (linhagem de células de adenocarcinoma epitelial colorretal humano).

Pitz (2018) avaliou a citotoxicidade de extrato hidroetanólico de jabuticaba obtido através de micro-ondas em linhagem de fibroblastos. Como conclusão, observou que na concentração de 0,05\% e 0,1\%, ocorre o aumento da viabilidade celular e nas concentrações de $0,15 \%$ e superiores, o extrato apresenta citotoxicidade.

Neste trabalho, a menor concentração de extrato testada foi de $0,156 \mathrm{mg} \mathrm{mL}^{-1}$, na qual os extratos de romã e jabuticaba apresentam viabilidade celular $105,5 \pm 1,8$ e 109,8 $\pm 2,8 \%$ respectivamente, em $24 \mathrm{~h}$. Condizente com a 
literatura apresentada, menores concentrações de extrato podem aumentar a viabilidade celular, assim como maiores concentrações a reduzem.

O extrato de semente de uva apresenta citotoxicidade severa em toda a faixa de concentração testada em 48h, entretanto, a viabilidade celular não decresce com o aumento da concentração do extrato.

No período de $24 \mathrm{~h}$, o extrato de semente de uva apresenta uma queda na viabilidade celular entre as concentrações de 0,156 e 0,312 $\mathrm{mg} \mathrm{mL}^{-1}$ e crescentes até a concentração de $2,5 \mathrm{mg} \mathrm{mL}^{-1}$. No período de $48 \mathrm{~h}$, a queda na viabilidade celular ocorre até a concentração de $0,625 \mathrm{mg} \mathrm{mL}^{-1}$, sendo que após esse período ocorre aumento da viabilidade, indicando que há uma faixa de concentração em que o extrato apresenta maior viabilidade celular com o aumento de sua concentração.

Este resultado é concordante com o encontrado por Pacheco (2017), que estudou a citotoxicidade do extrato de semente de nas concentrações de 6,$5 ; 0,65$; 0,065 e $0,0065 \%$. Ela observou que as duas maiores viabilidades celular ocorrem na concentração de 0,0065\% e 6,5\%, apresentando decaimento nas concentrações de extrato intermediárias.

Para Pacheco (2017), esse aumento da viabilidade conforme o aumento da concentração pode acontecer devido à capacidade do extrato em pigmentar, o que pode gerar interferência na absorbância.

\subsubsection{Citotoxicidade das matrizes}

Apesar dos extratos apresentarem em algum momento, citotoxicidade moderadas ou severas, não necessariamente as matrizes apresentarão citotoxicidade. Assim como discutido no item 5.11.2, já que os extratos são ligados fisicamente ou quimicamente a estrutura polimérica ( $\mathrm{He}$ et al., 2011; Vidal et al., 2016), sua difusibilidade no meio é reduzida, o que reduz sua atividade citotóxica.

A Figura 45 mostra a placa de cultura para o teste de citotoxicidade das matrizes. Nela, é possível se observar a cor roxa escura proveniente do corante MTS que é metabolizado por células viáveis, indicando a priori que há células vivas na placa. 
Figura 45: Fotografia da placa de microdiluição do ensaio de citotoxicidade das matrizes, na qual B) branco; C-) controle negativo; $\mathbf{C +}$ ) controle positivo; $\mathbf{C C}$ ) controle de células

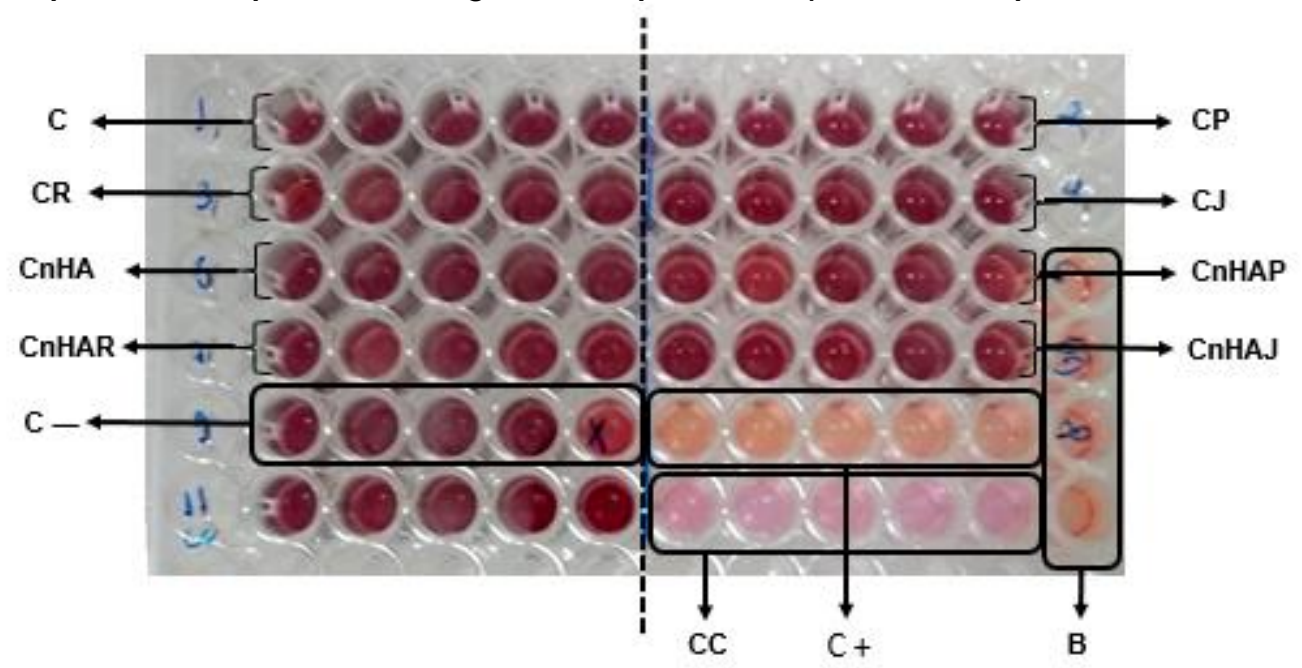

Fonte: Autoria própria

A Figura 46 mostra a porcentagem de viabilidade celular para as matrizes, nos períodos de 24 e 48h. Como esperado, as matrizes apresentaram menor citotoxicidade do que o dos extratos isolados.

Pode-se observar que no período de $24 \mathrm{~h}$, os extratos das matrizes não apresentam citotoxicidade, sendo que todos apresentam viabilidade celular superior a $70 \%$. Para o período de 48h, os extratos das matrizes CR, CnHAP, CnHAR e CnHAJ apresentam citotoxicidade.

Para ambos os períodos, os extratos das matrizes $\mathrm{C}$ e $\mathrm{CnHA}$ foram os que apresentaram maior viabilidade celular, sendo essas maiores que 90\%. Assim, temse um indicativo de que a adição de extrato às matrizes reduz a viabilidade celular.

Apesar dos valores menores de 70\% de viabilidade celular Alonso (2011) afirma que a avaliação da citotoxicidade de um biomaterial in vitro nem sempre representa seu comportamento em um momento pós-implante, ressaltando que os biomateriais podem não apresentar in vivo.

Lancelotti (2014) elaborou testes de citotoxicidade de hidrogéis de colágeno, gelatina e extrato de semente de uva através do método de difusão em ágar. Com isso concluiu que o aumento de extrato nos hidrogéis aumenta a viabilidade celular da linhagem VERO (ATCC CCL-81) de células de rim de macaco verde africano. 
Figura 46: Porcentagem de viabilidade celular das matrizes em (A) $24 \mathrm{~h} \mathrm{e} \mathrm{(B)} 48 \mathrm{~h}$
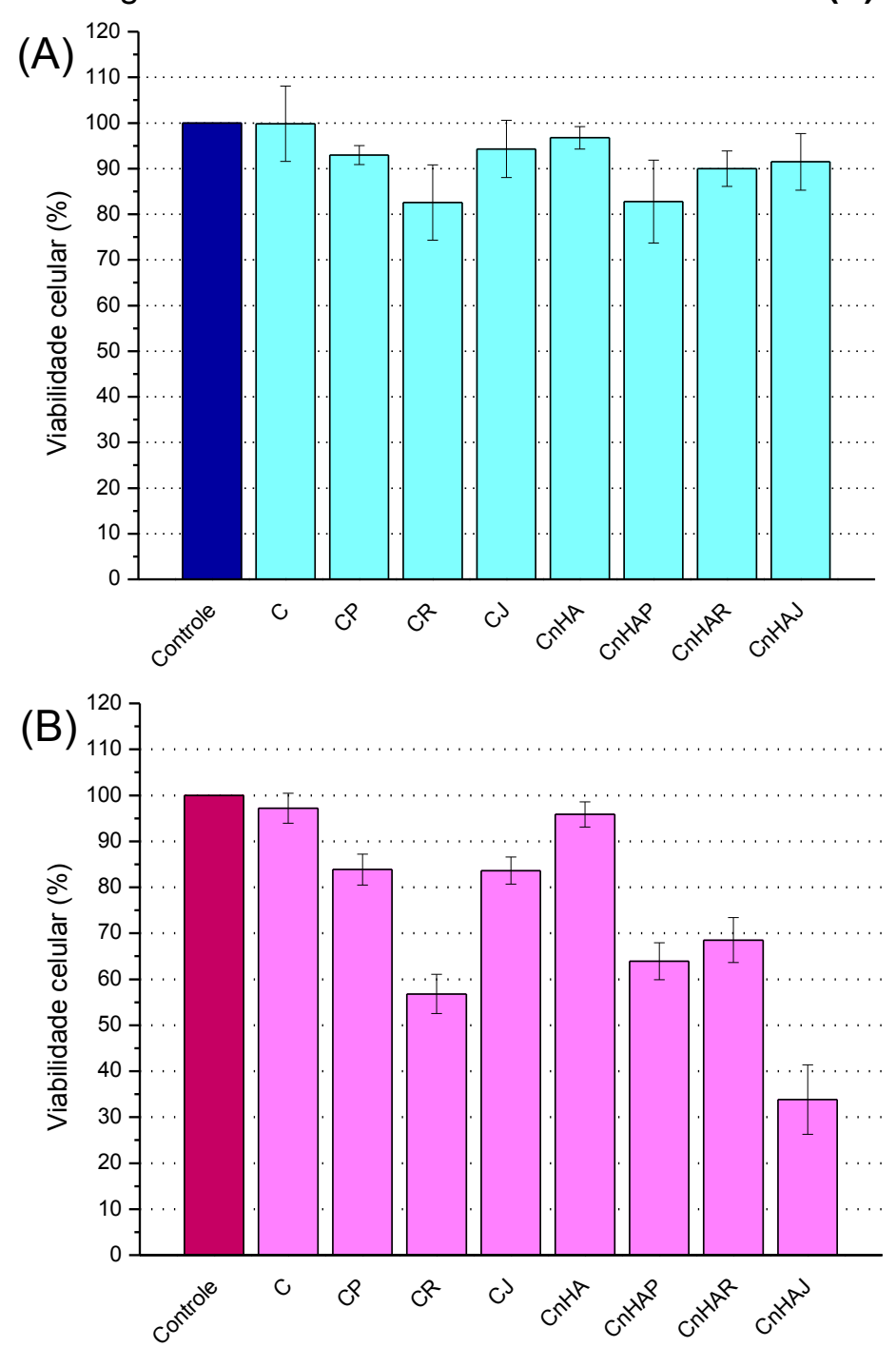

Fonte: Autoria própria

Huang et al. (2012) estudaram a citotoxicidade da proantocianidina incorporada em nanofibras de gelatina em células de fibroblasto de camundongo L-929. Para isso, eles cultivaram as células diretamente sobre o material e como resultado, obtiveram que essa incorporação não apenas aceleram a proliferação celular, mas também aumentam a eficiência de carregamento de fármacos.

Fleck et al. 2016 estudaram a eficácia do extrato de casca de romã incorporado em hidrogel de Carbomer 980 para tratamento de úlcera crônicas e descobriram que para concentrações menores que 0,49\% de extrato (massa/massa), o extrato é eficaz na cicatrização das feridas. 
A divergência dos resultados encontrados na literatura com os dessa parte do trabalho sugere que outra metodologia de ensaio ou análise possa ser empregada para se obter resultados mais concisos. Entretanto, isso não descarta o fato das matrizes $\mathrm{C}, \mathrm{CP}, \mathrm{CJ}$ e $\mathrm{CnHA}$ apresentarem extratos não-citotóxicos e adequadas para futuros testes in vivo. 


\section{CONCLUSÃO}

A obtenção da nHA, do colágeno aniônico e dos extratos de casca de romã e de jabuticaba foram possíveis. Com estes materiais, mais o extrato de semente de uva, foram preparadas matrizes distintas.

Os extratos atuaram como agentes reticulantes para o colágeno, aumentando sua estabilidade térmica e resistência enzimática. Em relação a atividade antimicrobiana, os extratos apresentaram atividade bactericida contra $S$. aureus, mas apenas a matriz $\mathrm{CR}$ apresentou halo de inibição

Dentro da faixa de concentrações testadas, os extratos apresentam citotoxicidade, e a nanohidroxiapatita um aumento na viabilidade celular. As matrizes em períodos de $24 \mathrm{~h}$ apresentam viabilidade celular superior a $70 \%$, e em períodos de 48h as matrizes CR, CnHAP, CnHAR e CnHAJ apresentaram citotoxicidade.

As matrizes apresentaram tamanho de poros e porosidade adequados para o crescimento de tecido ósseo, entretanto pela divergência de resultados constatados na literatura no que tange atividade citotóxica, novos ensaios deveriam ser feitos para confirmar o observado, e assim afirmar de fato quais as melhores matrizes que poderiam ser utilizadas para crescimento ósseo. Até o momento, conclui-se que apenas as matrizes $\mathrm{C}, \mathrm{CP}, \mathrm{CJ}$ e $\mathrm{CnHA}$ poderiam ser utilizadas para a etapa in vivo. 


\section{REFERÊNCIAS}

ALONSO, L. M. Avaliação de cimentos ósseos de fosfato de cálcio com adições de aluminato e silicato de cálcio. Orientador: Luis Alberto dos Santos. 2011. $175 \mathrm{f}$. Tese (Doutorado) - Universidade Federal do Rio Grande do Sul, Porto Alegre. 2011.

ALT, V.; CHEUNG, W. H.; CHOW, S. K. H.; THORMANN, U.; CHEUNG, E. N. M.; LIPS, K. S.; LEUNG, K. S. Bone formation and degradation behavior of nanocrystalline hydroxyapatite with or without collagen-type 1 in osteoporotic bone defects - An experimental study in osteoporotic goats. Injury, Londres, n. 47, p. S58-S65. 2016.

ALVAREZ, K; NAKAJIMA, H. Metallic scaffolds for bone regeneration. Materials, Basiléia, n. 2, p. 790-832. 2009.

ANDIA D. C.; SÉRGIO, P.; CARLOS, L. Tecido ósseo: aspectos morfológicos e histofisiológicos. Revista de Odontologia da UNESP, Araçatuba, v. 35(2), p. 191-198. 2006.

APARECIDA, A. H.; FOOK, M. V. L.; SANTOS, M. L. GUASTALDI, A. C. Estudo da influência dos íons $\mathrm{K}^{+}, \mathrm{Mg}^{2+}$, $\mathrm{SO}^{(2-)}$ e $\mathrm{CO}^{(2-)}$ na cristalização biomimética de fosfato de cálcio amorfo (ACP) e conversão a fosfato octacálcico (OCP). Química Nova, São Paulo, v. 30, n. 4, p. 892-896. 2007.

ARAHIRA, T.; TODO, M. Variation of mechanical behavior of $\beta$-TCP/collagen two phase composite scaffold with mesenchymal stem cell in vitro. Journal of the Mechanical Behavior of Biomedical Materials, Amsterdã, n. 61, p. 464-474. 2016.

ARRUDA, L. R. P.; SILVA, M. A. DE C.; MALERBA, F. G.; FERNANDES, M. DE C.; TURÍBIO, F. M.; MATSUMOTO, M. H. Fraturas expostas: Estudo epidemiológico e prospectivo. Acta Ortopedica Brasileira, Pinheiros, v. 17, n. 6, p. 326-330. 2009.

AZEVEDO, A. G. S.; STRECKER, K. Avaliação da influência da razão Ca/P nos valores de cristalinidade e crescimento de cristalitos durante a sinterização de pós de hidroxiapatita. Ecletica Quimica, Araraquara, v. 39, n. 1, p. 141-150. 2014.

BALDIN, J. C.; COLLOGRAI, K. C.; MICHELIN, E. C.; GODOY S. H. S.; FREGONESI R. C.; SOUZA, V. B.; TRINDADE, C . S. F.; FERNANDES, A. M.; TRINDADE M. A. Potencial antimicrobiano do extrato da casca de jabuticaba (myrciaria cauliflora) sobre bactérias gram positivas e negativas. In XII Congresso Latino Americano de Microbiologia e Higiene de Alimentos, Foz do Iguaçu. v. 1, n. 1. 2014.

BANERJEE, N.; TALCOTT, S.; SAFE, S.; MERTENS-TALCOTT, S. U. Cytotoxicity of pomegranate polyphenolics in breast cancer cells in vitro and vivo: Potential role of miRNA27a and miRNA-155 in cell survival and inflammation. Breast Cancer Research and Treatment, Nova lorque, v. 136, n. 1, p. 21-34. 2012.

BAUER, A. N.; KIRBY, W. M. M.; SHERRIS, J. C.; TURCK, M. Antibiotic susceptibility testing by a standardized single disc method. American Journal of Clinical Pathology, Cary. v. 45 , p. 493-496. 1966. 
BEZERRA, F;, FERREIRA, M. R.; FONTES, G. N.; DA COSTA FERNANDES, C. J.; ANDIA, D. C.; CRUZ, N. C.; ZAMBUZZI, W. F. Nano hydroxyapatite-blasted titanium surface affects pre-osteoblast morphology by modulating critical intracellular pathways. Biotechnology and Bioengineering, Hoboken, v. 114, n.8, p. 1888-1898. 2017.

BHUIMBAR, M. V.; BHAGWAT, P. K.; DANDGE, P. B. Extraction and characterization of acid soluble collagen from fish waste: Development of collagen-chitosan blend as food packaging film. Journal of Environmental Chemical Engineering, Amsterdã, v. 7, n. 2. 2019.

BROWN, P. W.; CONSTANTZ, B. Hydroxyapatite and related materials. 1 ed. Flórida, CRC Press. 1994.

BUCKINGHAM, J.; MUNASINGHE, V. R. N. Dictionary of Favonoids. 1 ed. Flórida, CRC Press. 2015.

CAMARGO, A. C.; REGITANO-D'ARCE, M. A. B.; RASERA, G. B.; CANNIATTI-BRAZACA, S. G.; DO PRADO-SILVA, L.; ALVARENGA, V. O., SHAHIDI, F. Phenolic acids and flavonoids of peanut by-products: Antioxidant capacity and antimicrobial effects. Food Chemistry, Schlieren, v. 237, p. 538-544. 2017.

CANEVAROLO Jr, S. V. Ciência dos Polímeros - Um texto básico para tecnólogos e engenheiros. 2 ed. São Paulo, Artliber. 2002.

CARVALHO, ELISABETE BARROS DE. Estudo da interacção entre proteínas e taninos: Influencia da presença de polissacarídeos. Orientador: Victor A. P. de Freitas, 2007, 193 f. Tese (Doutorado) - Departamento de Química, Universidade do Porto, Porto. 2007.

CASTRO-VAZQUEZ, L., ALAÑÓN, M. E., RODRÍGUEZ-ROBLEDO, V., PÉREZ-COELLO, M. S., HERMOSÍN-GUTIERREZ, I., DÍAZ-MAROTO, M. C., ARROYO-JIMÉNEZ, M. M. Cytoprotective Effects of Dried Grapefruit Peels (Citrus paradisi Macf.). Oxidative Medicine and Cellular Longevity, Londres, p. 1-12. 2016.

CEN, L.; LIU, W.; CUI, L.; ZHANG, W.; CAO, Y. Collagen tissue engineering: Development of novel biomaterials and applications. Pediatric Research, Nova lorque, v. 63, n. 5, p. 492-496. 2008.

CHEN, X. M.; TAIT, A. R.; KITTS, D. D. Flavonoid composition of orange peel and its association with antioxidant and anti-inflammatory activities. Food Chemistry, Schlieren, v. 218, p. $15-21.2017$.

CHENG, Y.; TAN, J.; LI, H.; KONG, X.; LIU, Y., GUO, R., PEI, M. Cardioprotective effects of total flavonoids from Jinhe Yangxin prescription by activating the PI3K/Akt signaling pathway in myocardial ischemia injury. Biomedicine and Pharmacotherapy, Issy-les-Moulineaux, v. 98, p. 308-317. 2018.

CHO, M. L.; HEO, Y. J.; PARK, M. K.; OH, H. J.; PARK, J. S.; WOO, Y. J.; JU, J. H. Grape seed proanthocyanidin extract (GSPE) attenuates collagen-induced arthritis. Immunology Letters, Amsterdã, v. 124, n. 2, p. 102-110. 2009.

Clinical and laboratory standards institute, CLSI. Methods for dilution antimicrobial susceptibility tests for bacteria that grow aerobically approved standard - $10 \mathrm{ed}$. CLSI Document M07-A9. Wayne. 2017. 
COSTA, A. C. F. M.; LIMA, M. G.; LIMA, L. H. M. A.; CORDEIRO, V. V; VIANA, K. M. S. Hidroxiapatita: Obtenção, caracterização e aplicações, Revista Eletrônica de Materiais e Processos, v. 3, p. 29-38. 2009.

CROZIER, A.; JAGANATH, I.B.; CLIFFORD, M. N. Dietary phenolics: chemistry, bioavailability and effects on health. Natural Product Reports, Cambridge, v. 26. n. 8 , p. 965-1096. 2009.

DAVIES, N. M.; YANEZ, J. A. Flavonoid pharmacokinetics: methods of analysis, preclinical and clinical pharmacokinetics,safety, and toxicology. John Wiley and Sons, Hoboken. 2013.

DRBOHLAVOVA, J.; ADAM, V.; RYVOLOVA, M.; ECKSCHLAGER, T.; HUBALEK, J.; KIZEK, R. Nanocarriers for anticancer drugs - new trends in nanomedicine. Current Drug Metabolism, Sharjah, v. 14, p. 547-64. 2013.

ELHENDAWI H.; FELFEL R. M.; ABD EL-HADY B.M.; REICHA F. M. Effect of synthesis temperature on the crystallization and growth of in situ prepared nanohydroxyapatite in chitosan matrix. ISRN Biomaterials, Nova lorque, v. 2014. 2014.

EPASINGHE, D. J.; BURROW, M. F.; YIU, C. K. Y. Effect of proanthocyanidin on ultrastructure and mineralization of dentine collagen. Archives of Oral Biology, Oxford, v. 84 p. 29-36. 2017.

FRESHNEY, R. I. Culture of animal cells: a manual of basic technique and specialized applications. 6 ed. New York, Wiley BlackWell, v.1. 2010.

GAO, W.; ZHOU, L.; YANG, Q.; WANG, L.; LIAN, Y. Method for identifying grape seed extract authenticity using hplc fingerprint spectrum. Chenguang Biotech Group Co., Ltd. US 2019/0025265 A1. United States. 2019.

GHOMI H.; FATHI M. H.; EDRIS H. Preparation of nanostructure hydroxyapatite scaffold for tissue engineering applications. Journal of Sol-Gel Science and Technology, Nova lorque, v.58, p. 642-650. 2011.

GIANNITRAPANI, L.; SORESI, M.; BONDI, M. L.; MONTALTO, G.; CERVELLO, M. Nanotechnology applications for the therapy of liver fibrosis. World Journal of Gastroenterology, Pleasanton. v. 20, n. 23, p. 7242-7251. 2014.

GIGLIOTI, A. F. Matrizes acelulares de colágeno elastina a partir da desvitalizarão do pericárdio bovino: caracterização química, físico-química e estrutural. Orientador: Gilberto Goissis, 2005, 80 f. Dissertação (Mestrado), Universidade de São Paulo. Instituto de Química de São Carlos. 2005.

GOISSIS G.; SUZIGAN S.; PARREIRA D. R.; MANIGLIA J. V.; BRAILE D. M.; RAYMUNDO, S. R. O. Preparation and characterization of collagen-elastin matrices from blood vessels intended as small diameter vascular grafts. Artificial Organs, Hoboken, v. 24 n. 3 , p. 217-223. 2000.

GOMES, D. S.; IKEDA, R.; MARIA, F.; RODRIGUES, D.; RODRIGUES, A. Comparação do teor de flavonoides de Calendula officinalis em cultivo orgânico em diferentes estações climáticas. Revista Diálogos Interdisciplinares, Mogi das Cruzes, v. 7, n.3, p. 75-89. 2018.

GÓRNIAK, I.; BARTOSZEWSKI, R.; KRÓLICZEWSKI, J. Comprehensive review of antimicrobial activities of plant flavonoids. Phytochemistry Reviews, Dordrecht, v. 18. 2019. 
GRANATO, D.; SHAHIDI, F.; WROLSTAD, R.; KILMARTIN, P.; MELTON, L. D.; HIDALGO, F. J.; FINGLAS, P. Antioxidant activity, total phenolics and flavonoids contents: Should we ban in vitro screening methods? Food Chemistry, Schlieren. v. 264, p 471-475. 2018.

GREEN, B.; YAO, X.; GANGULY, A.; XU, C.; DUSEVICH, V.; WALKER, M. P.; WANG, Y. Grape seed proanthocyanidins increase collagen biodegradation resistance in the dentin/adhesive interface when included in an adhesive. Journal of Dentistry, Londres, v. 38, n. 11, p. 908-915. 2010.

GROTEWOLD, E. The Science of Flavonoids. 1 ed. Nova lorque, Springer. 2006.

GULLON B.; PINTADO, M. E.; PEREZ-ALVAREZ, J. A.; VIUDA-MARTOS, M. Assessment of polyphenolic profile and antibacterial activity of pomegranate peel (Punica granatum) flour obtained from co-product of juice extraction. Food Control, Londres, v. 59, p.94-98. 2016.

HE, L.; MU, C.; SHI, J.; ZHANG, Q.; SHI, B.; LIN, W. Modification of collagen with a natural cross-linker, procyanidin. International Journal of Biological Macromolecules, Amsterdã, v. 48, n. 2 , p. $354-359.2011$.

HE, X.; FAN, X.; FENG, W.; CHEN, Y.; GUO, T.; WANG, F. TANG, K. Incorporation of microfibrillated cellulose into collagen-hydroxyapatite scaffold for bone tissue engineering.

International Journal of Biological Macromolecules, Amsterdã, v. 115, p. 385-392. 2018.

HENCH, L. L. An introduction to bioceramics. 2 ed. Florida. Imperial College Press. 2013.

HESS J. R.; BROHI K.; DUTTON R. P.; HAUSER C. J.; HOLCOMB J. B.; KLUGER Y, The coagulopathy of trauma: a review of mechanisms. The Journal of Trauma and Acute Care Surgery, Filadélfia, v. 65, p.748-754. 2008.

HORN M. M.; MARTINS V. C. A.; PLEPIS A. M. G. Interaction of anionic collagen with chitosan: Effect on thermal and morphological characteristics. Carbohydrate Polymers, Oxford, v. 77, n. 2, p. 239-243. 2009.

HUANG, C. H.; CHI, C. Y.; CHEN, Y. S.; CHEN, K. Y.; CHEN, P. L.; YAO, C. H. Evaluation of proanthocyanidin-crosslinked electrospun gelatin nanofibers for drug delivering system. Materials Science and Engineering C: Materials for Biological Applications, Amsterdã, v. 32, n. 8, p. 2476-2483. 2012.

Instituto Brasileiro de Geografia e Estatística, IBGE. Levantamento Sistemático da Produção Agrícola. Uva 2019. Brasil. Disponível em: https://sidra.ibge.gov.br/home/lspa/brasil .

Acessado em 15 de out. de 2019.

International Organization for Standardization, ISO/TS 80004-2:2015 (en). Nanotechnologies - Vocabulary - Part 2: Nano-objects. Genebra, 2015, Disponivel em:

https://www.iso.org/obp/ui/\#iso:std:iso:ts:80004:-2:ed-1:v1:en . Acessado em 21 de out de 2019.

International Organization for Standardization, ISO/TS 80004-2:2015 (en). Nanotechnologies - Plain language explanation of selected terms from the ISO/IEC 80004 series, 2017.

Genebra. Disponível em: https://www.iso.org/obp/ui/\#iso:std:iso:tr:18401:ed-1:v1:en . Acesso em 21 de out de 2019.

International Organization for Standardization. ISO 10993-12: biological evaluation of medical devices - part 12: sample preparation and reference materials. Genebra. 2012. 
InternationaL Organization for Standardization. ISO 10993-5: biological evaluation of medical devices - part 5: tests for in vitro cytotoxicity. Genebra. 2009.

JASTRZEBSKA, M.; TARNAWSKA, D.; WRZALIK, R.; CHROBAK, A.; GRELOWSKI, M.; WYLEGALA, E.; RATUSZNA, A. New insight into the shortening of the collagen fibril Dperiod in human cornea. Journal of Biomolecular Structure and Dynamics, Nova lorque, v. 35, n.3, p. 551-563. 2017.

KANNICHT, C. Post-translational modification of proteins: tools for functional proteomics. 3 ed. Humana Press. Heidelberg. 2019.

KANNU, P., BATEMAN, J., SAVARIRAYAN, R. Clinical phenotypes associated with type II collagen mutations. 2012. Disponível em: http://doi.org/10.1111/i.1440-1754.2010.01979.x. Acessado em 20 de jan. de 2020.

KARSDAL, M. A. Biochemistry of collagens, laminins and elastin: structure, function and biomarkers. 2016. Disponível em: https://doi.org/10.1016/C2015-0-05547-2. Acessado em 20 de jan. de 2020.

KHADEMHOSSEINI, A.; LANGER, R. A decade of progress in tissue engineering. Nature Protocols, Londres, v. 11, n.10, p. 1775-1781. 2016

KHOO, H. E.; AZLAN, A.; TANG, S. T.; LIM, S. M. Anthocyanidins and anthocyanins: colored pigments as food, pharmaceutical ingredients, and the potential health benefits. Food \& Nutrition Research, Abingdon, v. 61, n. 1. 2017.

KLANČNIK, A.; PISKERNIK, S.; JERŠEK,B.; MOŽINA, S. S. Evaluation of diffusion and dilution methods to determine the antibacterial activity of plant extracts. Journal of Microbiological Methods, Amsterdã, v. 81 p. 121-126. 2010.

KOZLOWSKA, J.; SIONKOWSKA, A.; OSYCZKA, A. M.; DUBIEL, M. Stabilizing effect of carbodiimide and dehydrothermal treatment crosslinking on the properties of collagen/hydroxyapatite scaffolds. Polymer International, Oxford, v. 66, n. 8, p. 1164-1172. 2017.

KRUGER, M. J.; DAVIES, N.; MYBURGH, K. H.; LECOUR, S. Proanthocyanidins, anthocyanins and cardiovascular diseases. Food Research International, Oxford, v. 59, p.41-52, 2014.

LAJNEF, L.; CACERES, I.; TRINSOUTROT, P.; CHARRIER-EL BOUHTOURY, F.; AYED, N.; CHARRIER, B. Effect of Punica granatum peel and Melia azedarach bark extracts on durability of European beech and maritime pine. European Journal of Wood and Wood Products, Heidelberg, v. 76, n. 6, p. 1725-1735. 2018.

LANGDAHL, B.; FERRARI, S.; DEMPSTER, D. W. Bone modeling and remodeling: potential as therapeutic targets for the treatment of osteoporosis. Therapeutic Advances in Musculoskeletal Disease, Londres, v. 8, n. 6, p. 225-235. 2016.

LANZA R.; LANGER, R.; VACANTI J. Principles of Tissue Engineering, Academic Press, Nova lorque, USA, 3 ed. 2007.

LEITE-LEGATTI, A. V.; BATISTA, A. G.; DRAGANO, N. R. V.; MARQUES, A. C., MALTA, L. G.; RICCIO, M. F.; MARÓSTICA, M. R. Jaboticaba peel: Antioxidant compounds, antiproliferative and antimutagenic activities. Food Research International, Oxford, v. 49, n. 1, p. 596-603. 2012. 
LI, W.; GUA, X.; LU, Y.; WANG, L.; FAN, A.; SUI, M.; YU, H. Amorphous nanosized silicon with hierarchically porous structure for highperformance lithium ion batteries. Energy Storage Materials, Amsterdã, v. 7, p. 203-208. 2017.

LIMA, A. J. B. Caracterização e atividade antioxidante da jabuticaba (Myrciaria cauliflora Berg). Orientador: Angelica Duarte Correa, 2009, 175 f. Tese (Doutorado). Universidade Federal de Lavras, Lavras. 2009.

LIMA, A. J. B; DUARTE, A. C; ALVES, A. P. C; CARVALHO ALVES. Caracterização química do fruto jabuticaba (Myrciaria cauliflora Berg) e de suas frações. Archivos

Latinoamericanos de Nutricion, Caracas, v.58, n.4, p. 416-421. 2008.

LIMA, L. S. Efeito Tyndall, Revista de Ciência Elementar, Porto, v. 2, n.3, p. 233. 2014.

LIU, D.; NIKOO, M.; BORAN, G.; ZHOU, P.; REGENSTEIN, J. M. Collagen and Gelatin. Annual Review of Food Science and Technology, Palo Alto, v. 6, n. 1, p. 527-557. 2015.

LIU, W.; QIAN, G.; LIU, L.; ZHANG, B.; FAN, X. A simple method to controlled synthesis of nano hydroxyapatite in different particle size. Materials Letters, Amsterdã, v. 217, p. $177-180.2018$.

LIU, X.; ZHENG, C.; LUO, X.; WANG, X.; JIANG, H. Recent advances of collagen-based biomaterials: Multi-hierarchical structure, modification and biomedical applications. Materials Science and Engineering C: Materials for Biological Applications, Amsterdã, v. 99, p. 1509-1522. 2019.

LIU, Z.; YIN, X.; YE, Q.; HE, W.; GE, M.; ZHOU, X. ZOU, S. Periodontal regeneration with stem cells-seeded collagen-hydroxyapatite scaffold. Journal of Biomaterials Applications, Londres, v. 31(1), p. 121-131. 2016.

LORENZI, H., MATOS, F.J.A. Plantas Medicinais no Brasil: Nativas e Exóticas, 2 ed. p.350-351. São Paulo, Instituto Plantarum de Estudos da Flora. 2008.

LUCARINI, M.; SCIUBBA, F.; CAPITANI, D.; DI COCCO, M. E.; D’EVOLI, L.; DURAZZO, A.; LOMBARDI BOCCIA, G. Role of catechin on collagen type I stability upon oxidation: a NMR approach. Natural Product Research, Abingdon, v. 34, p. 53-62. 2019.

MABRY, T.J.; MARKHAM, K. R.; THOMAS, M. B. The systematic identification of flavonoids. Berlin, Springer. 1970.

MAINI, S.; HODGSON, H. L.; KROL, E. S. The UVA and Aqueous Stability of Flavonoids Is Dependent on B-Ring Substitution. Journal of Agricultural and Food Chemistry, Washington, v.60, p. 6966-6976. 2012.

MICHALSKA-SIONKOWSKA, M.; WALCZAK, M.; SIONKOWSKA, A. Antimicrobial activity of collagen material with thymol addition for potential application as wound dressing. Polymer Testing, Londres, v. 63, p. 360-366. 2017.

MANOLAGAS, S. C.; DREZNER, M. K.; MULDER, J. E. Normal skeletal development and regulation of bone formation and resorption (2018). Disponível em:

https://www.uptodate.com/contents/normal-skeletal-development-and-regulation-of-boneformation-and-resorption?csi=588cf002-f645-4d0c-916d-

083dc3cd7a42\&source=contentShare. Acessado em 15 jun. 2019.

MARIEB, E.N. Human anatomy \& physiology. San Francisco, Pearson Benjamin Cummings. 2007. 
MARQUES, T. R.; BRAGA, M. A.; CESAR, P. H. S.; MARCUSSI, S.; CORRÊA, A. D. Jabuticaba (Plinia jaboticaba) skin extracts as inhibitors of phospholipases A2 and proteases. Anais Da Academia Brasileira de Ciências, Rio de Janeiro, v. 91, n. 2. 2019.

MATSUURA-HACHIYA, TAICHI, Y. A., TASUKU, M., NISHIYAMA, T. Type IV collagen aggregates promote keratinocyte proliferation and formation of epidermal layer in human skin equivalents. Experimental Dermatology, Chichester, v. 27, p. 443-448. 2017.

MELLO, L. M. R. Vitivinicultura brasileira: panorama 2017. Disponível em: https://ainfo.cnptia.embrapa.br/digital/bitstream/item/187913/1/Comunicado-Tecnico-207.pdf. 2018. Acessado em: 15/10/2019.

MEMAR, M.; ADIBKIA, K.; FARAJNIA, S.; KAFIL, H. S.; YEKANI, M., ALIZADEH, N.; GHOTASLOU, R. The grape seed extract: a natural antimicrobial agent against different pathogens. Reviews in Medical Microbiology, Londres, v. 30, n. 3, p. 173-182. 2019.

MICHALSKA-SIONKOWSKA M.; WALCZAK M.; SIONKOWSKA A. Antimicrobial activity of collagen material with thymol addition for potential application as wound dressing. Polymer Testing, Londres, v. 63, p. 360-366. 2017.

MOBASHERPOUR, I; HESHAJIN, M. S.; KAZEMZADEH, A.; ZAKERI, M. Synthesis of nanocrystalline hydroxyapatite by using precipitation method. Journal of Alloys and Compounds, Amsterdã, v. 430, n. 2, p. 330-333. 2007.

MONSHI, A.; FOROUGHI, M. R.; MONSHI, M. R. Modified Scherrer Equation to Estimate More Accurately Nano-Crystallite Size Using XRD. World Journal of Nano Science and Engineering, Irvine, v. 2, n. 3, p. 154-160. 2012.

MOUSSA, D. G.; APARICIO, C. Present and future of tissue engineering scaffolds for dentinpulp complex regeneration. Journal of Tissue Engineering and Regenerative Medicine, Hoboken, v. 13, n. 1, p. 58-75. 2019.

MUCALO, M. Hydroxyapatite (HAp) for biomedical applications. 1 ed. Amsterdã, Elsevier Ltd. 2015.

MUYONGA, J. H.; COLE, C. G. B.; DUODU, K. G. Fourier transform infrared (FTIR) spectroscopic study of acid soluble collagen and gelatin from skins and bones of young and adult Nile perch (Lates niloticus). Food Chemistry, Amsterdã, v. 86, n. 3, p. 325-332. 2004.

NAIR R.; SEVUKARAJAN M.; MOHAMMED T.; BADIVADDIN, C. K.; KUMAR A. Collagen based drug delivery systems: A Review. Journal of Innovative Trends in Pharmaceutical Sciences, Xiraz, v.1, p. 288-304. 2010.

Nanomaterials Definition fact sheet. Center for International Environmental Law (CIEL). 2014. Disponível em https://www.ciel.org/reports/nanomaterials-definition-fact-sheet-nov2014/. Acessado em 21 de out de 2019.

NASCIMENTO, A. P. R. Quantificação dos taninos dos vinhos por transformada de Fourier dos espectros no infravermelho médio (FTIR). Orientador: Licenciada Olga Maria Carrasqueira Laureano, 2011, 70 f. Dissertação (Mestrado) - Instituto Superior de Agronomia, Universidade Técnica de Lisboa, Lisboa. 2011.

NEWMAN, M. G.; TAKEI, H. H.; CARRANZA, F.A. Periodontia Clínica. 9. ed. Rio de Janeiro, Guanabara Koogan S.A. Cap. 2, p. 31-50. 2004. 
NUNES, M. A.; PIMENTEL, F.; COSTA, A. S. G.; ALVES, R. C.; OLIVEIRA, M. B. P. P. Cardioprotective properties of grape seed proanthocya.nidins: An update. Trends in Food Science and Technology, Oxford, v. 57, p. 31-39. 2016.

OKONOGI, S.; DUANGRAT, C.; ANUCHPREEDA, S.; TACHAKITTIRUNGROD, S.; CHOWWANAPOONPOHN, S. Comparison of antioxidant capacities and cytotoxicities of certain fruit peels. Food Chemistry, Amsterdã, v. 103, n. 3, p. 839-846. 2007.

OLIVEIRA, D. A.; SALVADOR, A. A.; SMÂNIA, A.; SMÂNIA, E. F. A.; MARASCHIN, M.; FERREIRA, S. R. S. Antimicrobial activity and composition profile of grape (Vitis vinifera) pomace extracts obtained by supercritical fluids. Journal of Biotechnology, Amsterdã, v. 64(3), p. 423-432. 2013.

OLIVEIRA, S. V.; MEDEIROS, K. M.; ARAÚJO, E. P.; BRAGA, C. R. C.; ARAÚJO, E. M. Caracterização química e morfológica do pirofosfato de cálcio obtido por via úmida. Revista Eletrônica de Materiais e Processos, v. 3, p. 11-20. 2009.

PACHECO, J. M. Avaliação da citotoxicidade do extrato de semente de uva em cultura de células pulpares. Orientador: Ana Paula Dias Ribeiro, 2017, 63 f. Dissertação (Mestrado). Universidade de Brasília, Brasília. 2017.

PANCHE, A. N.; DIWAN, A. D.; CHANDRA, S. R. Flavonoids: An overview. Journal of Nutritional Science, Cambridge, v. 5. 2016.

PARENTEAU-BAREIL, R.; GAUVIN, R.; BERTHOD, F. Collagen-Based Biomaterials for Tissue Engineering Applications. Materials, Basiléia, v. 3, n. 3, p. 1863-1887. 2010.

PARHIZ, H.; ROOHBAKHSH, A.; SOLTANI, F.; REZAEE, R.; IRANSHAHI, M. Antioxidant and anti-inflammatory properties of the citrus flavonoids hesperidin and hesperetin: An updated review of their molecular mechanisms and experimental models. Phytotherapy Research, Oxford, v. 29, n. 3, p. 323-331. 2015.

PEARSON, J. J.; GERKEN, N., BAE, C.; LEE, K., SATSANGI, A.; MCBRIDE, S. GUDA, T. In vivo hydroxyapatite scaffold performance in infected bone defects. Journal of Biomedical Materials Research, Hoboken, p. 1-10. 2019.

PINTO, D. C. S.; JUNIOR, A. A. M.; MOTA, W. M.; ALMEIDA, P. C. C.; GÓMEZ, D. DE S.; GEMPERLI, R. Custo-efetividade do uso do curativo de colágeno e alginato no tratamento de áreas doadoras de enxerto de pele de espessura parcial. Revista Brasileira de Queimaduras, Florianopolis, v. 16, n. 2, p. 1-6. 2017.

PLAZA, M.; BATISTA, Â. G.; CAZARIN, C. B. B.; SANDAHL, M.; TURNER, C.; ÖSTMAN, E., MARÓSTICA JÚNIOR, M. R. Characterization of antioxidant polyphenols from Myrciaria jaboticaba peel and their effects on glucose metabolism and antioxidant status: A pilot clinical study. Food Chemistry, Amsterdã, v. 211, p. 185-197. 2016.

POLO-CORRALES, L; LATORRE-ESTEVES, M; RAMIREZ-VICK, J. Scaffold design for bone regeneration. Journal of Nanoscience and Nanotechnology, Valencia, v. 14, p. 15-56. 2014.

PONTEL, C. Z.; BOABAID, F. Regeneração tecidual guiada em recessões gengivais - o uso do enxerto gengival autógeno e das membranas de colágeno - uma revisão, Periodontia, Taubaté, v. 29, n. 2, p. 51-59. 2019. 
QUINLAN, E.; LÓPEZ-NORIEGA, A.; THOMPSON, E.; KELLY, H. M.; CRYAN, S. A.; O'BRIEN, F. J. Development of collagen-hydroxyapatite scaffolds incorporating PLGA and alginate microparticles for the controlled delivery of rhBMP-2 for bone tissue engineering. Journal of Controlled Release, Amsterdã, v. 198, p. 71-79. 2015.

REY, C.; COMBES, C.; DROUET, C.; GLIMCHER, M. J. Bone mineral: update on chemical composition and structure, Osteoporosis International, Secaucus v. 20, n. 12, p. 1013-1021. 2009.

RIAZ, T.; ZEESHAN, R.; ZARIF, F.; ILYAS, K.; MUHAMMAD, N.; SAFI, S. Z. REHMAN, I. U. FTIR analysis of natural and synthetic collagen. Applied Spectroscopy Reviews, Secaucus, v. 53, n. 9, p. 703-746. 2018.

ROCKENBACH, I. I.; JUNGFER, E., RITTER, C.; SANTIAGO-SCHÜBEL, B.; THIELE, B., FETT, R.; GALENSA, R. Characterization of flavan-3-ols in seeds of grape pomace by CE, HPLC-DAD-MS $n$ and LC-ESI-FTICR-MS. Food Research International, Oxford, v. 8, n. 2, p. 848-855. 2012.

RODRIGUES, S.; FERNANDES, F. A. N.; DE BRITO, E. S.; SOUSA, A. D.; NARAIN, N. Ultrasound extraction of phenolics and anthocyanins from jabuticaba peel. Industrial Crops and Products, Amsterdã, v. 69, p. 400-407. 2015.

ROUQUEROL, J.; AVNIR, D.; FAIRBRIDGE, C. W.; EVERETT, D. H.; HAYNES, J. H.; PERNICONE, N.; RAMSAY, J. D. F.; SING, K. S. W.; UNGER, K. K. Recommendation for the characterization of porous solids. International Union of Pure and Applied Chemistry, Berlin, v. 66, p. 1739-1758. 1994.

RUARO, A. F. Ortopedia e traumatologia: temas fundamentais e a reabilitação. 1 ed. Umuarama, Elenco. 2004.

RUSSO, M.; FANALI, C.; TRIPODO, G.; DUGO, P.; MULEO, R.; DUGO, L.; MONDELLO, L. Analysis of phenolic compounds in different parts of pomegranate (Punica granatum) fruit by HPLC-PDA-ESI/MS and evaluation of their antioxidant activity: application to different Italian varieties. Analytical and Bioanalytical Chemistry, Heidelberg, v. 410, n. 15, p. 3507-3520. 2018.

RYAN A. J.; GLEESON J. P., MATSIKO, A.; THOMPSON E. M.; O'BRIEN F. J. Effect of different hydroxyapatite incorporation methods on the structural and biological properties of porous collagen scaffolds for bone repair. Journal of Anatomy, Londres, v. 227, n. 6, p. 732-745. 2015.

SANDEN, K. W.; KOHLER, A.; AFSETH, N. K.; BÖCKER, U.; RONNING, S. B.; LILAND, K. $\mathrm{H}$.; Pedersen, M. E. The use of Fourier-transform infrared spectroscopy to characterize connective tissue components in skeletal muscle of Atlantic cod (Gadus morhua L.). Journal of Biophotonics, Weinheim, v. 12, p. 1-9. 2019.

SANNE, D.; GUILLEMYN, B.; SYX, D.; SYMOENS, S. Type III collagen affects dermal and vascular collagen fibrillogenesis and tissue integrity in a mutant Col3a1 transgenic mouse model. Matrix Biology, Amsterdã, v. 70, n. C, p. 72-83. 2018.

SANTOS, D. S.; FARIAS RODRIGUES, M. M. Atividades farmacológicas dos flavonoides: um estudo de revisão. Estação Científica (UNIFAP), Amapá, v. 7, n. 3, p. 29. 2017. 
SARFRAZ, S.; NASEEM, B.; AMIN, S.; MUJAHID, M.; Synthesis and Characterization of Nano Hydroxyapatite. Advanced Materials Research, Pfaffikon, v. 264-265, p. 1370-1375. 2011.

SHAHABI, S.; NAJAFI, F.; MAJDABADI, A.; HOOSHMAND, T.; NAZARPAK, M. H.; KARIMI, B.; FATEMI, S. M. Effect of Gamma Irradiation on Structural and Biological Properties of a PLGA-PEG-Hydroxyapatite Composite. The Scientific World Journal, Nova lorque, v. 2014, p. 9. 2014.

SHANTHI, P. M.; ASHOK, M.; BALASUBRAMANIAN, T.; RIYASDEEN, A.; AKBARSHA, M. A. Synthesis and characterization of nano-hydroxyapatite at ambient temperature using cationic surfactant. Materials Letters, Amsterdã v. 63, n. 24-25, p. 2123-2125. 2009.

SHAVANDI, A.; BEKHIT, A. E. D. A.; SAEEDI, P.; IZADIFAR, Z.; BEKHIT, A. A.; KHADEMHOSSEINI, A. Polyphenol uses in biomaterials engineering. Biomaterials, Amsterdã, v. 167, p. 91-106. 2018.

SILVA, M. C.; SOUZA, V. B. DE, THOMAZINI, M.; DA SILVA, E. R.; SMANIOTTO, T.; CARVALHO, R. A. DE.; FAVARO-TRINDADE, C. S. Use of the jabuticaba (Myrciaria cauliflora) depulping residue toproduce a natural pigment powder with functional properties. LWT - Food Science and Technology, Alhambra, v. 55, n. 1, p. 203-209. 2014.

SIONKOWSKA, A.; GRABSKA, S. Preparation and characterization of 3D collagen materials with magnetic properties. Polymer Testing, Londres, v. 62, p. 382-391. 2017.

SLOSARCZYKA, A.; PASZKIEWICZA, Z.; PALUSZKIEWICZ, C. FTIR and XRD evaluation of carbonated hydroxyapatite powders synthesized by wet methods. Journal of Molecular Structure, Amsterdã, v. 657, n. 66, p. 744-747. 2005.

SMITH J. W. Molecular pattern in native collagen. Nature Publishing Group, Londres, v. 219, p. 157-158. 1968.

STEVENS, M. M. Biomaterials for bone tissue engineering. Materials Today, Oxford, v. 11, n. 5 , p. $18-25.2008$.

SUMCZYNSKI, D.; BUBELOVA, Z.; SNEYD, J.; ERB-WEBER, S.; MLCEK, J. Total phenolics, flavonoids, antioxidant activity, crude fibre and digestibility in non-traditional wheat flakes and muesli. Food Chemistry, Amsterdã, v. 174, p. 319-325. 2015.

SUN, M.; SU, X.; DING, B.; HE, X.; LIU, X.; YU, A.; LOU, H.; ZHAI, G. Advances in nanotechnology-based delivery systems for curcumin. Nanomedicine, Londres, v.7, n.7, p.1085-100. 2012.

SUNDARAM C. P.; KEENAN A. C. Evolution of hemostatic agents in surgical practice. Indian Journal of Urology, Bombaim, v. 26, n. 3, p. 374-78. 2010.

The European Committee on Antimicrobial Susceptibility Testing. Breakpoint tables for interpretation of MICs and zone diameters. Version 9.0. 2019. Disponível em: http://www.eucast.org. Acessado em 07 de nov. de 2019.

THOMSON, R. C.; YASZEMSKI, M. J.; POWERS, J. M.; MIKOS, A. G. Hydroxyapatite fiber reinforced poly( $\alpha$-hydroxy ester) foams for bone regeneration. Biomaterials, Amsterdã, v. 19, n. 21, p. 1935-1943. 1998. 
VELASCO, M. A.; NARVÁREZ-TOVAR, C. A.; GARZÓN-ALVARADO, D. A. Design, Materials, and Mechanobiology of Biodegradable Scaffolds for Bone Tissue Engineering, BioMed Research International, Londres, v. 2015, p. 21.2015.

VICENTE, O.; BOSCAIU, M. Flavonoids: Antioxidant compounds for plant defence... and for a healthy human diet. Notulae Botanicae Horti Agrobotanici Cluj-Napoca, Cluj-Napoca v. 46, n. 1, p. 14-21. 2018.

VIDAL, C. M. P.; ZHU, W.; MANOHAR, S.; AYDIN, B.; KEIDERLING, T. A.; MESSERSMITH, P. B.; BEDRAN-RUSSO, A. K. Collagen-collagen interactions mediated by plant-derived proanthocyanidins: A spectroscopic and atomic force microscopy study. Acta Biomaterialia, Amsterdã, v. 41, p.110-118. 2016.

VILLELA, F. Hospital do estado do Rio é o segundo do país em operações ortopédicas (2017) Disponível em: http://agenciabrasil.ebc.com.br/geral/noticia/2017-06/hospital-doestado-do-rio-e-o-segundo-do-pais-em-operacoes-ortopedicas. Acessado em 21 nov. 2019.

WAFA, B. A.; MAKNI, M.; AMMAR, S.; KHANNOUS, L.; HASSANA, A. BEN, BOUAZIZ, M., GDOURA, R. Antimicrobial effect of the Tunisian Nana variety Punica granatum L. extracts against Salmonella enterica (serovars Kentucky and Enteritidis) isolated from chicken meat and phenolic composition of its peel extract. International Journal of Food Microbiology Amsterdã, v. 241, p. 123-131. 2017.

WANG, Y.; CHEN, S.; YU, O. Metabolic engineering of flavonoids in plants and microorganisms. Applied Microbiology and Biotechnology, Heidelberg, v. 91, n. 4, p. 949-956. 2011.

WOJNAR, R. Bone and cartilage - its structure and physical properties. Biomechanics of Hard Tissues. Andreas Oechsner, p. 1-75. 2010.

YANG, X.; LI, Y., LIU, X., ZHANG, R., FENG, Q. In vitro uptake of hydroxyapatite nanoparticles and their effect on osteogenic differentiation of human mesenchymal stem cells. Stem Cells International, Londres, v. 2018, p. 10. 2018.

YU, X.; TANG, X.; Gohil, S. V.; Laurencin, C. T. Biomaterials for Bone Regenerative Engineering. Advanced Healthcare Materials, Weinheim, v. 4(9), p. 1268-1285. 2015.

YUAN, G.; LV, H.; TANG, W.; ZHANG, X.; SUN, H. Effect of chitosan coating combined with pomegranate peel extract on the quality of Pacific white shrimp during iced storage. Food Control, Oxford, v. 59, p. 818-823. 2016. 


\section{APÊNDICE A}

Fotomicrografia por MEV das matrizes:

- A) C; A') C d6h
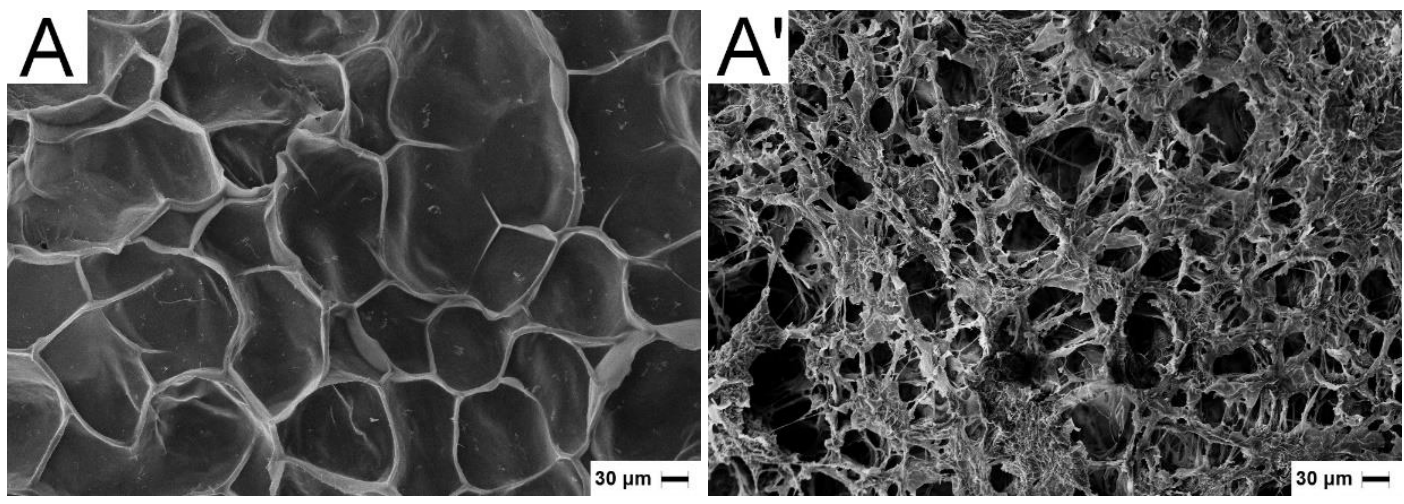

- B) $\mathrm{CnHA}$; B') $\mathrm{CnHA}$ d6h
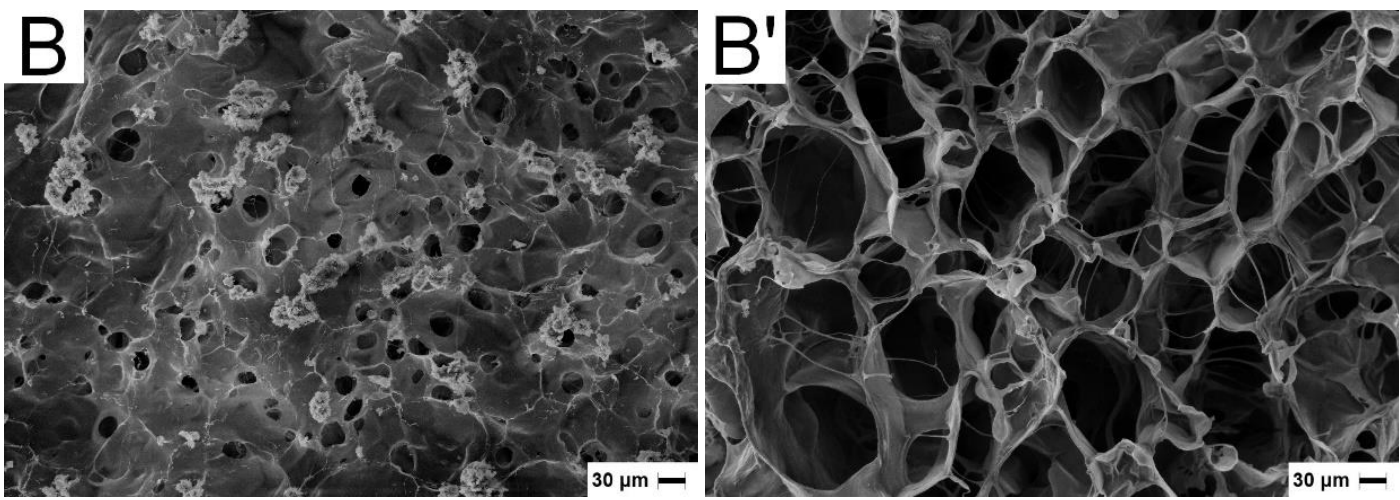

- C) $\mathrm{CP}$; C') CP d6h
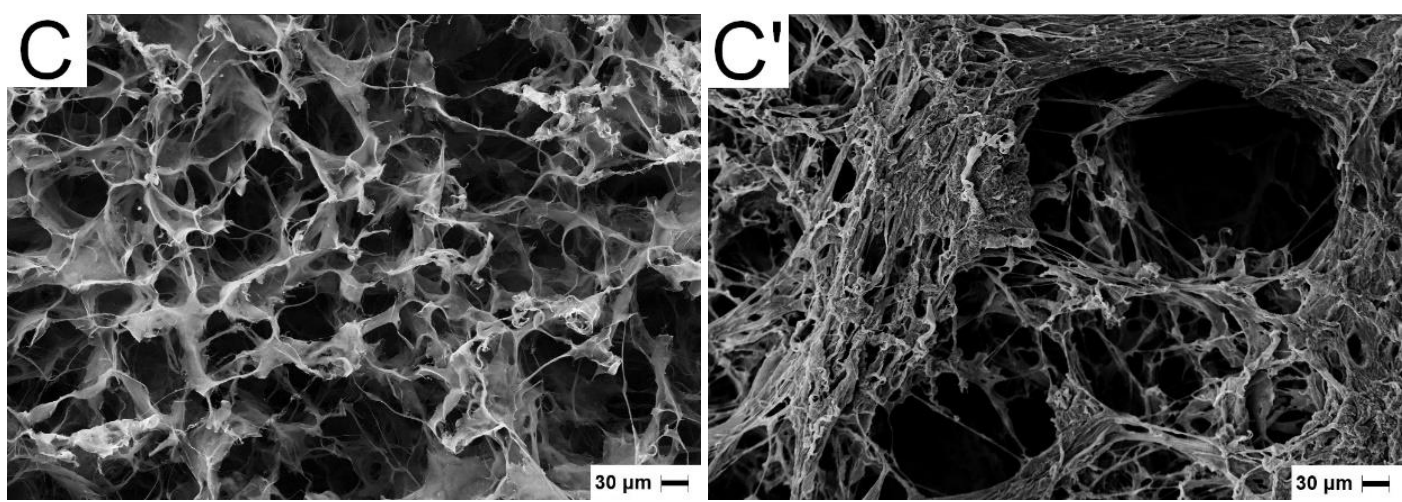
- D) CnHAP; D') CnHAP d6h

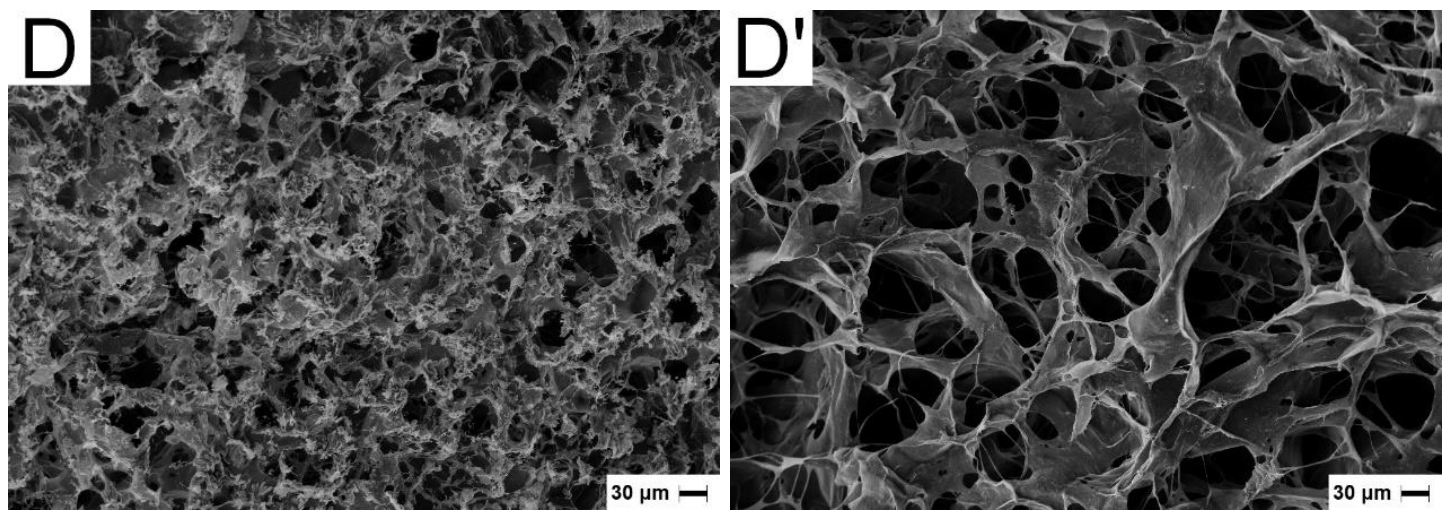

- E) CR; E') CR d6h
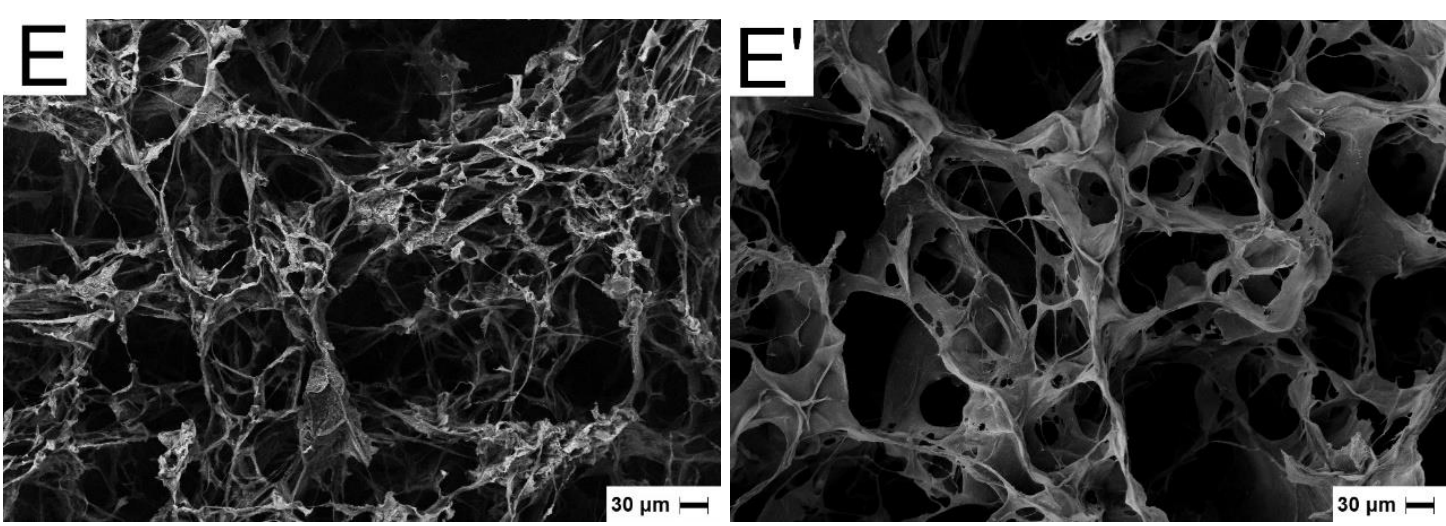

- F) CnHAR; F') CnHAR d6h
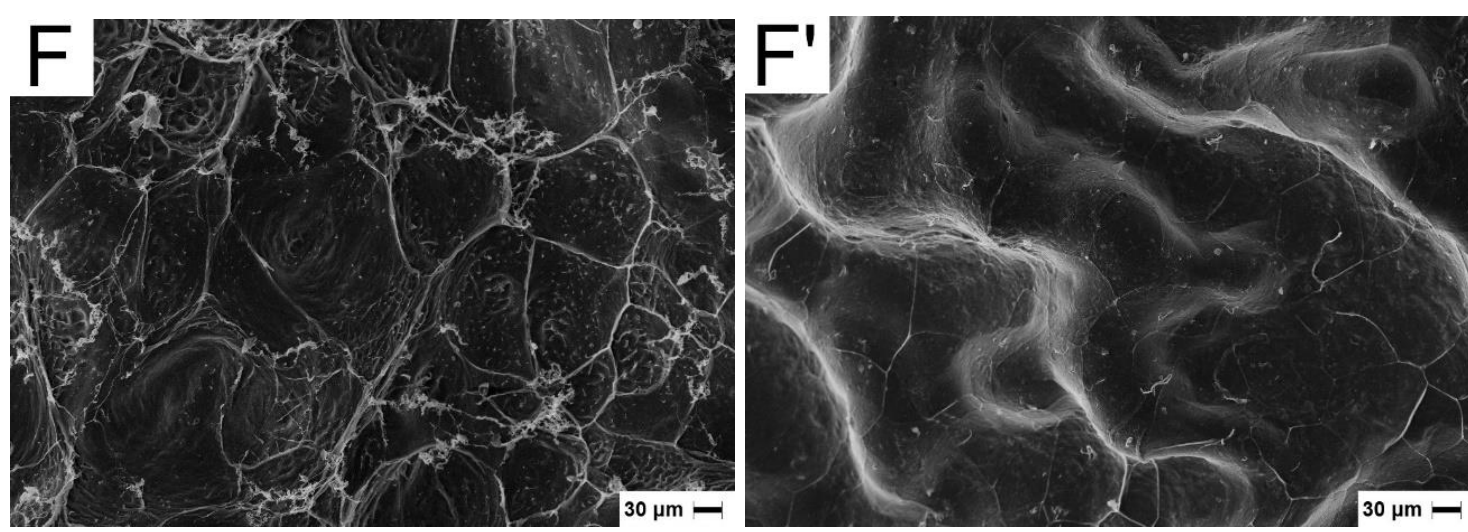
- G) CJ; G') CJ d6h
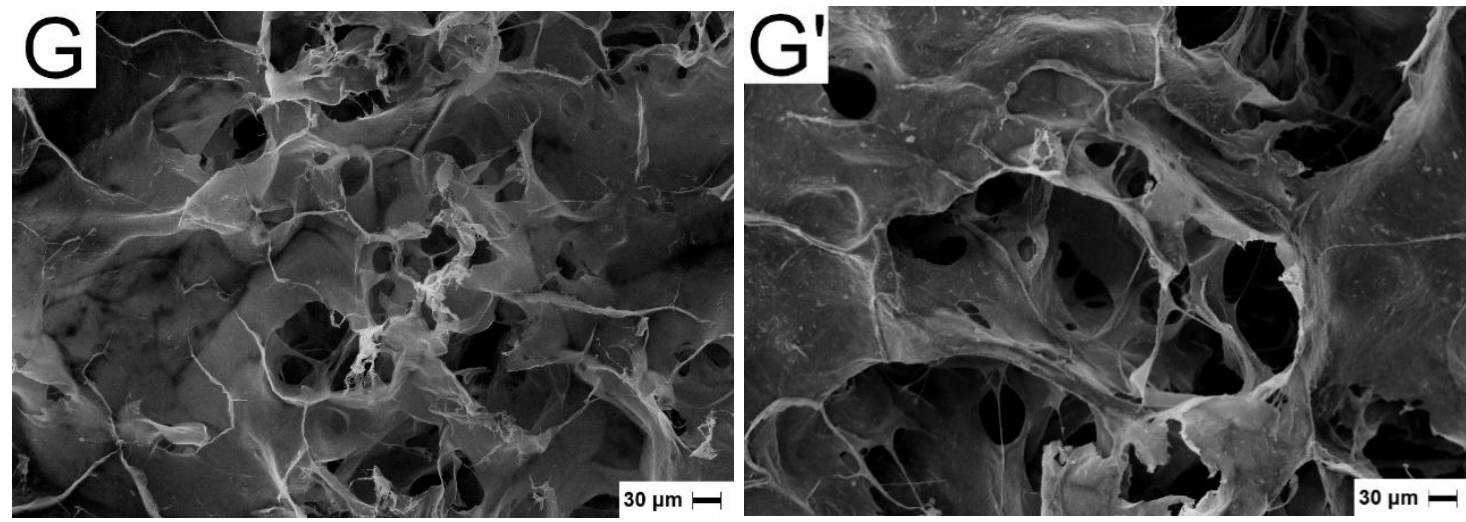

- H) CnHAJ; H') CnHAJ d6h

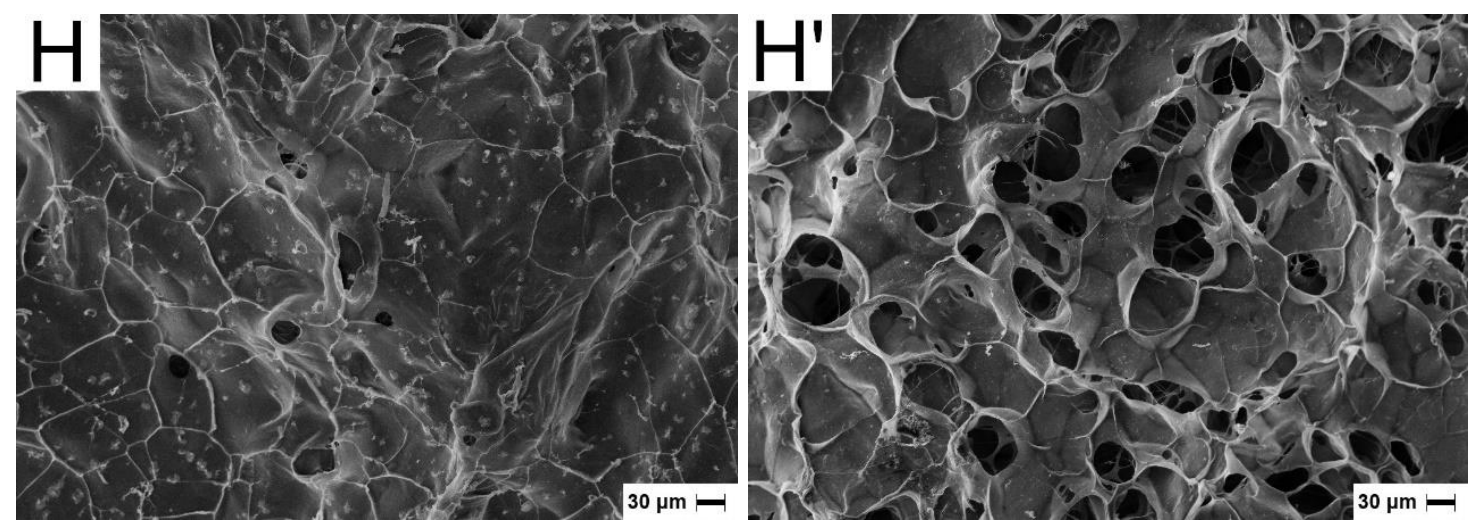

